\title{
Late Jurassic-Early Cretaceous horizontal tectonics drives the Jbel Amsittene Anticline in the Haha Basin, Morocco
}

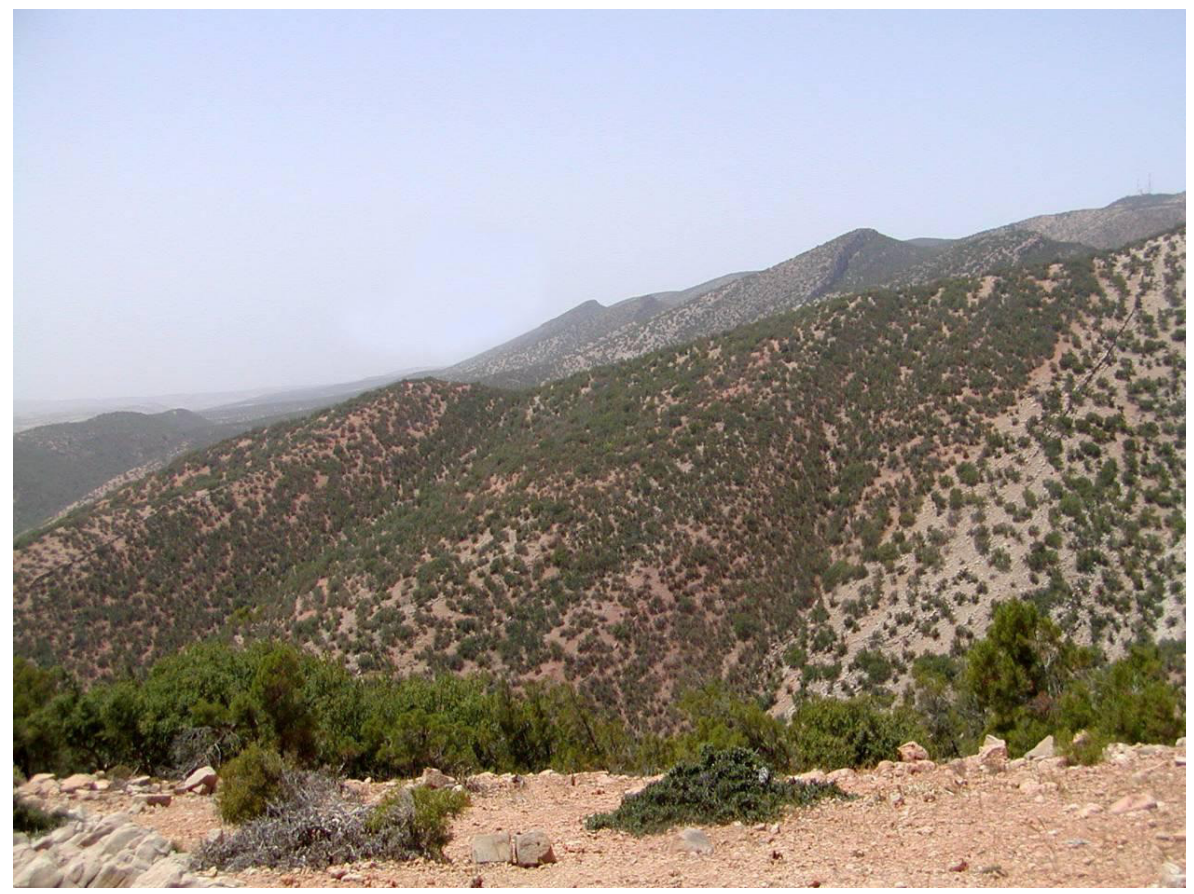

MSc. Thesis

by

Kirsten Brautigam, David Fernández-Blanco and Jop M. Klaver

SUPERVISOR:

Dr. Giovanni Bertotti

Free University Amsterdam

FACUlty of EARTh AND LifE SCIENCES

Institute of EARTh SCIENCES

Department of Tectonics and Structural Geology

\begin{abstract}
The western Moroccan basins are considered to have acted as stable regions during the postrift phase of the Central Atlantic rifting. Field data, however, show a period of Late Jurassic to Early Cretaceous exhumation. N-S shortening led to the formation of the Jbel Amsittene, located at the northwest most of Haha basin. This anticline was formed in the Late Jurassic to Early Cretaceous, as indicated by syn-tectonic wedges for this period. It is a salt-cored fault propagation fold verging north, with a Triassic salt acting as a detachment plane. Regional kinematic indicators and structures show NNW-SSE to NNE-SSW shortening during the postrift phase. These facts discard the "salt-drives-tectonics" theory to let "tectonic-drives-salt" one to rise.

Keywords: Morocco, Jbel Amsittene, Haha Basin, Essaouira Basin, Late Jurassic, Early Cretaceous, Exhumation.
\end{abstract}




\section{Contents}

1 Introduction 1

2 Regional geological evolution $\mathbf{2}$

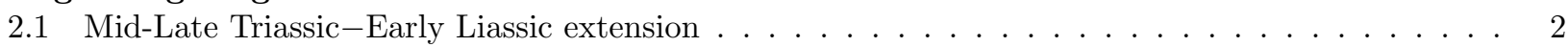

2.2 Late Jurassic to Cretaceous deformation . . . . . . . . . . . . . . . . . . . . . . . . . . . 4

2.3 Late Cretaceous to recent compression . . . . . . . . . . . . . . . . . . . . . . 4

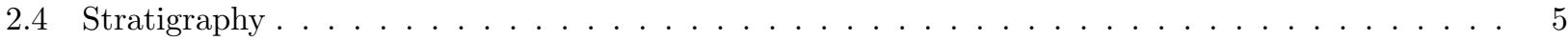

3 Outcrops 9

3.1 Outcrops near profile $E-E^{\prime} \ldots \ldots \ldots \ldots \ldots$

3.1 .1 Outcrop $n^{e r} 62 \ldots \ldots \ldots \ldots \ldots \ldots \ldots$

3.1 .2 Outcrop $n^{e r} 65 \ldots \ldots \ldots \ldots \ldots \ldots$

3.1 .3 Outcrops $n^{e r} 88$ and $89 \ldots \ldots \ldots \ldots \ldots \ldots \ldots$

3.1 .4 Outcrop $n^{e r} 85 \ldots \ldots \ldots \ldots \ldots \ldots \ldots \ldots$

3.1 .5 Outcrop $n^{e r} 86 \ldots \ldots \ldots \ldots \ldots \ldots$

3.1 .6 Outcrop $n^{e r} 68 \ldots \ldots \ldots \ldots \ldots \ldots \ldots \ldots \ldots$

3.2 Outcrops near profile $A-A^{\prime} \ldots \ldots \ldots \ldots \ldots \ldots \ldots$

3.2 .1 Outcrop $n^{e r} 14 \ldots \ldots \ldots \ldots \ldots \ldots$

3.2 .2 Outcrop $n^{e r} 75 \ldots \ldots \ldots \ldots \ldots \ldots$

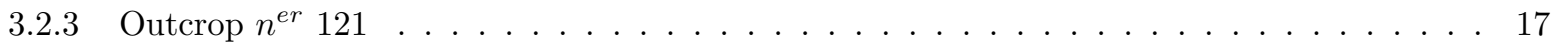

3.2.4 Interpretation and conclusions for the neptunian dykes . . . . . . . . . . . . . . . 18

3.3 Outcrops near profile $B-B^{\prime} \ldots \ldots \ldots \ldots \ldots \ldots \ldots \ldots \ldots$

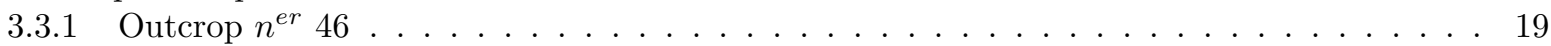

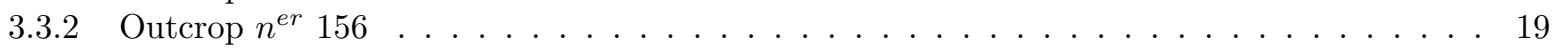

3.3 .3 Outcrop $n^{e r} 35 \ldots \ldots \ldots \ldots \ldots \ldots \ldots \ldots$

3.4 Other outcrops not close to the profiles . . . . . . . . . . . . . . . . . . . 21

3.4 .1 Outcrop $n^{e r} 57 \ldots \ldots \ldots \ldots \ldots \ldots \ldots \ldots$

4 Profiles $\quad 23$

4.1 Profiles perpendicular to the fold axis . . . . . . . . . . . . . . . . . . 23

4.1 .1 Profile $E-E^{\prime} \ldots \ldots \ldots \ldots \ldots \ldots \ldots \ldots \ldots$

4.1 .2 Profiles parallel to $E-E^{\prime} . \ldots \ldots \ldots \ldots \ldots \ldots \ldots \ldots$

4.2 Profiles parallel to fold axis . . . . . . . . . . . . . . . . . . . . . . 25

4.3 Interpretation and extrapolation of the profiles . . . . . . . . . . . . . . . . . 25

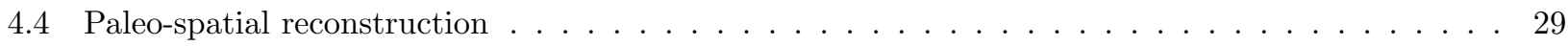

4.5 Seismic interpretation . . . . . . . . . . . . . . . . . . . . . 30

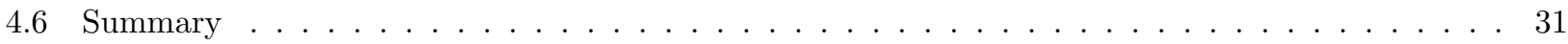

5 Salt tectonics

6 Structural evolution 33

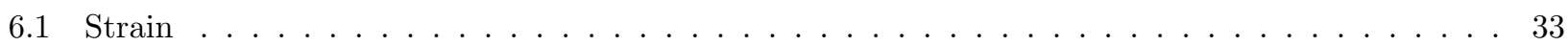

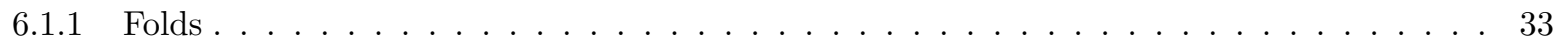

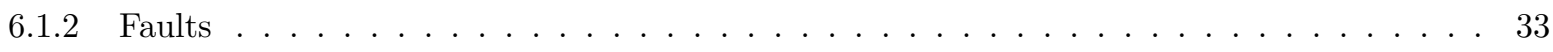

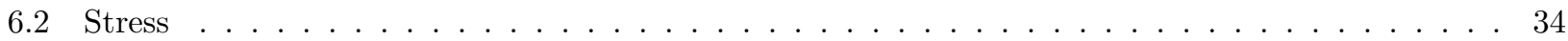

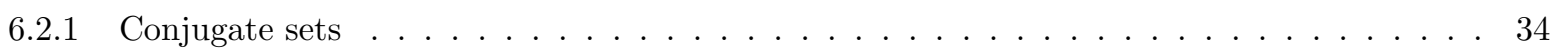

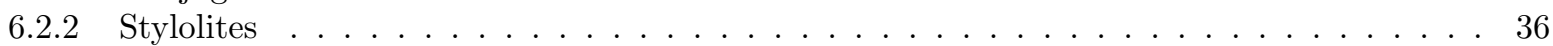

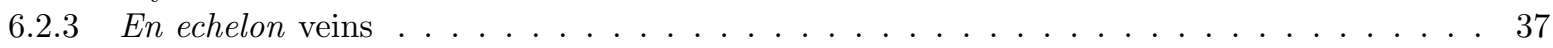

6.2 .4 Neptunian dykes . . . . . . . . . . . . . . . . . . . . . . . . . . . . . . . . . . . . . . . . . . . . . . . . . . . . . .

6.3 Tectonic phases on the Jbel Amsittene . . . . . . . . . . . . . . . . . . . . . . . 38

6.3.1 Discussion structural evolution . . . . . . . . . . . . . . . . . . 39

$\begin{array}{lll}7 & \text { Discusion } & 40\end{array}$

8 Conclusion $\quad 41$

9 Acknowledgements $\quad 42$ 
11 Appendix $\mathbf{4 6}$

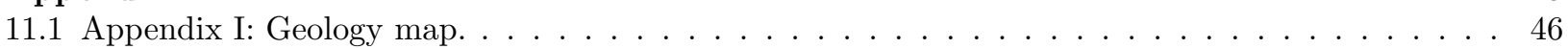

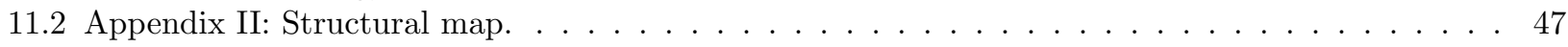

11.3 Appendix III: Profiles $H-H^{\prime}$ and $K-K^{\prime} \ldots \ldots \ldots \ldots \ldots \ldots \ldots$

11.4 Appendix IV: Profile $E-E^{\prime} . \ldots \ldots \ldots$. . . . . . . . . . . . . . . . . . . . . . . 49

11.5 Appendix V: Profile $A-A^{\prime} \ldots \ldots \ldots \ldots \ldots$

11.6 Appendix VI: Profile $B-B^{\prime} . \ldots \ldots \ldots \ldots \ldots \ldots$

11.7 Appendix VII: Profile $I-I^{\prime} . \ldots \ldots \ldots \ldots \ldots \ldots \ldots$

11.8 Appendix VIII: Profile $G-G^{\prime} \ldots \ldots \ldots \ldots \ldots \ldots$

11.9 Appendix IX: Profile $F-F^{\prime} . \ldots \ldots \ldots \ldots \ldots \ldots$ 


\section{List of Figures}

1 Location of the Haha basin in the western part of Morocco. . . . . . . . . . . . . . . . . 1

2 Major tectono-sedimentary units of western Morocco. . . . . . . . . . . . . . . . . . 2

3 Paleo-geographic map of the world in the Early Jurassic. . . . . . . . . . . . . . . . . . . . 3

4 Geological map of the western High Atlas. . . . . . . . . . . . . . . . . . . . . . . . 4

6 Lower Cretaceous on the Neknafa syncline. . . . . . . . . . . . . . . . . . . . 6

7 Discordant contact between the J7b-n1 and Quaternary deposits. . . . . . . . . . . . . . . 6

8 Subsidence curve and sedimentation rate for the Amsittene anticline area. . . . . . . . . . . . 8

9 Location of the most important outcrops in the area. . . . . . . . . . . . . . . . . . . 9

10 Positions of important outcrops along profile $E-E^{\prime} \ldots \ldots \ldots \ldots$

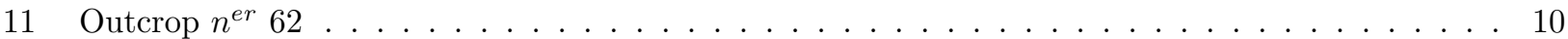

12 Stereoplot of a the folds and faults. . . . . . . . . . . . . . . . . . . . . . . . . . 10

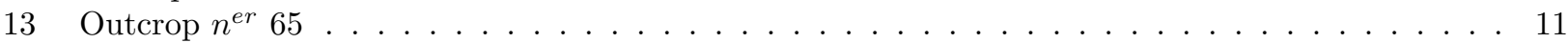

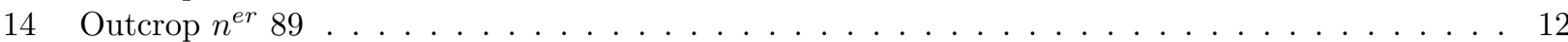

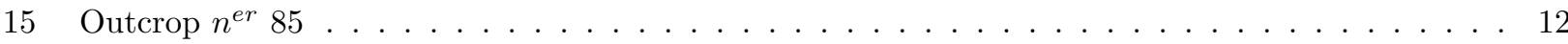

16 Stereoplot of neptunian dyke . . . . . . . . . . . . . . . . . . . . 13

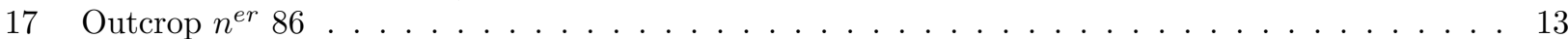

18 Stereoplot of a syn-sedimentary ramp fold during the Late Jurassic. . . . . . . . . . . . . . . . . 14

19 Outcrop $n^{e r} 68 \ldots \ldots \ldots \ldots \ldots \ldots \ldots \ldots$

20 Stress directions of conjugate sets at outcrop $68 . \ldots \ldots \ldots$. . . . . . . . . . . . . . . 15

21 Positions of important outcrops along profile $A-A^{\prime} \ldots \ldots \ldots \ldots$

22 Outcrop $n^{e r} 14 \ldots \ldots \ldots \ldots \ldots \ldots \ldots \ldots$

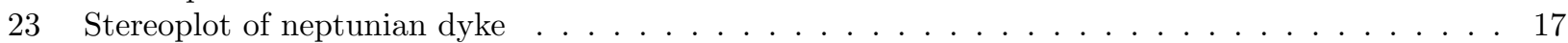

24 Stereoplot of neptunian dyke . . . . . . . . . . . . . . . . . . . . . . . . . 17

25 Stereoplot of neptunian dykes . . . . . . . . . . . . . . . . . . . . . . 18

26 Positions of important outcrops along profile $B-B^{\prime} \ldots \ldots \ldots \ldots$

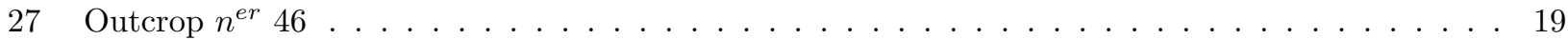

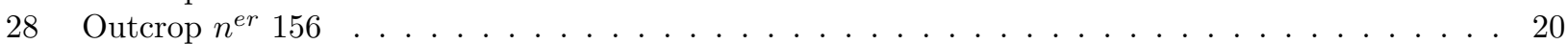

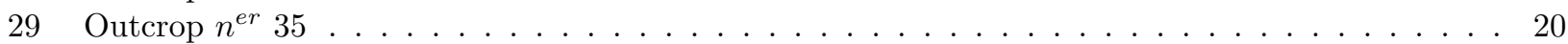

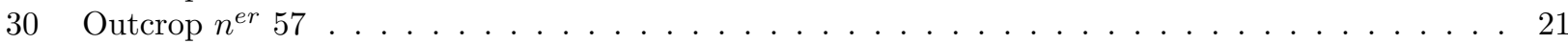

31 Stereoplot of outcrop . . . . . . . . . . . . . . . . . . . . . . . . 22

32 Dips and pictures of important outcrops along profile $E-E^{\prime}$. . . . . . . . . . . . . . . . 23

33 Structural interpretation of profile $E-E^{\prime} \ldots \ldots \ldots \ldots \ldots$. . . . . . . . . . . . . . . . 24

34 Extrapolation of profile $H-H^{\prime} \ldots \ldots \ldots \ldots \ldots \ldots \ldots \ldots$

35 Structural interpretation of profile $F-F^{\prime}$, parallel to the fold axis. . . . . . . . . . . . . . . . 25

36 Geological profiles from west to east. . . . . . . . . . . . . . . . . . . . . . 26

37 Panorama view of the Neknafa syncline, north of the Jbel Amsittene. . . . . . . . . . . . . . . 27

38 Extrapolation of profile $A-A^{\prime}$ as evolved in three different scenarios. . . . . . . . . . . . . . . . 28

39 Paleo-spatial reconstruction of profile $A-A^{\prime} \ldots \ldots \ldots \ldots \ldots$

40 Seismic profile north of the Jbel Amsittene. . . . . . . . . . . . . . . . . . . . . . . 30

41 Salt mine and adjacet formations. . . . . . . . . . . . . . . . . . . . . . . 32

42 Stereoplots for the fold-axes in Jbel Amssitene. . . . . . . . . . . . . . . . . . . . . . . . . 33

43 Stereoplot with the poles of all the fault planes. . . . . . . . . . . . . . . . . . . . . 34

44 Principal stresses of the conjugate sets . . . . . . . . . . . . . . . . . . . . . 35

45 Orientations of the stylolite teeth if the bedding is horizontal. . . . . . . . . . . . . . . 36

46 Model of the stylolites formation at outcrop $n^{e r} 46 \ldots \ldots \ldots$

47 Model of en echelon veins formation. . . . . . . . . . . . . . . . . . . . . . 37

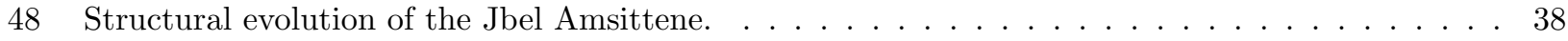

49 Structural map with the shortening directions. . . . . . . . . . . . . . . . . . . . 40 


\section{List of Tables}

1 Chronostratigraphic and environmental column for the Jbel Amsittene area. . . . . . . . . . . . . 7

2 Orientations of the fault planes and their specific striations at outcrop 88 and $89 \ldots \ldots 11$

3 Stress orientations of all the conjugate sets at outcrop $n^{\text {er }} 68 \ldots \ldots \ldots$

4 Orientations of the stylolites at outcrop $n^{e r} 46 \ldots \ldots \ldots \ldots$

5 Stress orientations of the conjugate set at outcrop $n^{e r} 35 \ldots \ldots \ldots$. . . . . . . . . . . . 21

6 Decrease in amount of shortening to the east. . . . . . . . . . . . . . . . . 27

7 Differences in thicknesses of J7b-n1 and N2-3ab formations, on profile $A-A^{\prime}$ and $B-B^{\prime}$. . . . 27

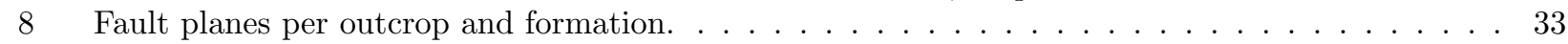

9 Stress orientations of the conjugate sets. . . . . . . . . . . . . . . . . . . . 34

10 Orientation of the neptunian dykes and their $\sigma_{3} \ldots \ldots \ldots \ldots \ldots$

11 Resume tectonic features with their assumable age. . . . . . . . . . . . . . . . . 38 


\section{Introduction}

This study is a small part of a research to provide more understanding in the vertical movements of Morocco during the Jurassic-Early Cretaceous, determined by Ghorbal et al. (2008). One of the areas to make a good investigation of these vertical movements and deformations is the Jbel Amsittene in the Haha Basin. The Jbel Amsittene is an anticline located in the north-westernmost part of the Haha Basin (Hafid, 2006), that extends from the coast in the west to $20 \mathrm{~km}$ into the east, as observed in (Figure 1). The Haha Basin is bounded by the Essaouira Basin in the north and the Western High Atlas (WHA) in the south and east. The Haha and Essaouira basins are divided by an east-west fault of Triassic age.

Previous studies concluded that the Amsittene anticline is formed by salt diapirism that triggered later deformation. Le Roy and Piqué (2001) state that in the Essaouira basin, Triassic salt diapirs associated with folded Jurassic deposits are locally exposed throughout the present western coastal plain. The Triassic salt diapirs result from faulting of the passive margin which triggered and enhanced diapiric ascent during Late Jurassic-Early Cretaceous Atlasic deformation (quoted from page 364, Le Roy and Piqué, Piqué et al., 1998).

The objective of this study is to clarify the driving forces and the timing of formation of the Jbel Amsittene anticline. The Amsittene anticline is one of many comparable structures in the western-Moroccan basins. Therefore the understanding of its formation might help to constrain a detailed geological evolution of the postrift phase of the Moroccan margin, which makes the area highly interesting. In most of the studies, this margin is supposed to have acted as a stable area, only affected by thermal relaxation and withdrawal and diapirism of Triassic salts. This would suggest that the Jbel Amsittene anticline is probably formed during the Atlasic Orogenesis. But this has never been checked before by real structural fieldwork.

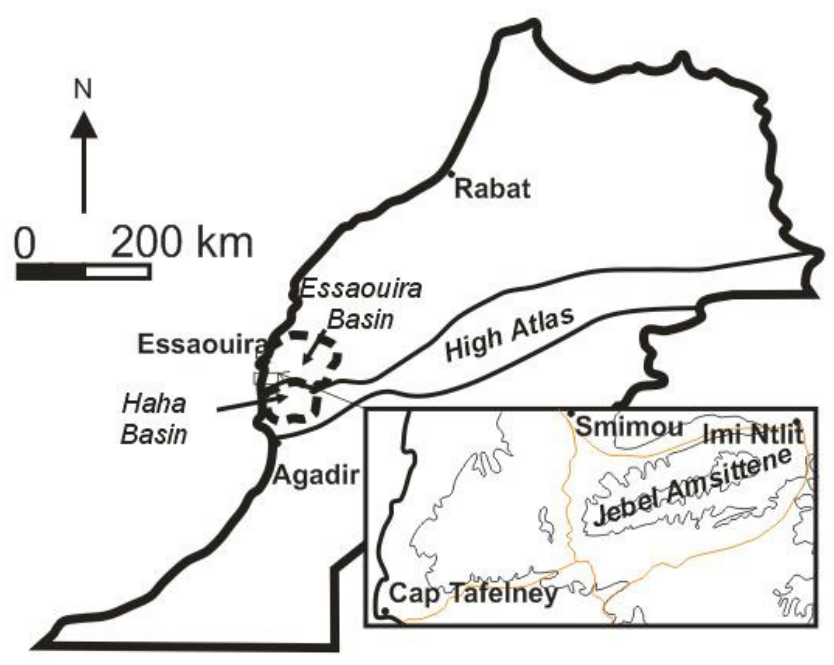

Figure 1: Location of the Haha basin in the western part of Morocco.

We did an intensive detailed structural fieldwork in the Jbel Amsittene area to clarify if the vertical movement suffered by the anticline is: $(i)$ due to the forces associated by the mentioned diapirism or, on the contrary, (ii) horizontal compressional stresses, which makes the location and emplacement of salt diapirs easier. Another interesting point of the study is to specify the timing of formation of the anticline by looking for possible syntectonic structures. For this project several cross sections have been made based on detailed structural field data obtained in May 2008.

Since the Jbel Amsittene anticline is a well exposed anticline it can give the answer to the questions addressed in this introduction. If the Jbel Amsittene anticline is formed during the Atlasic Orogenesis then there should be neither syntectonic wedges nor on-lapping relations within the Mesozoic formation. Furthermore, if this anticline is triggered by diapirism during Late Jurassic until Early Cretaceous, as Hafid (2000) suggests for some of the anticlines in the Essaouira Basin, then this could be verified in the field. 


\section{Regional geological evolution}

In the geological evolution of the opening of the Central Atlantic, two important tectonic periods can be distinguished in the Agadir basin (Figure 2):

Central Atlantic rift, with a synrift stage, from probably Ladinian until the end of Hettangian, and a postrift stage from the Sinemurian until the Late Cretaceous (Medina, 1995). During drifting, the trajectory of the African plate changed, rotating in northern direction (Olivet et al, 1984), leading to the generation of the Rif fold-and-trust-belt, and later to;

Atlas formation during the Alpine orogenesis, from Late Cretaceous until present.

The period in between the synrift stage of the Central Atlantic and the Alpine orogenesis is considered to be a tectonic quite phase, in which the postrift stage prevailed. Since the Pleinsbachian there is salt tectonics (Zühlke et al., 2004, Hafid, 2000, Hafid et al., 2000).

Based on previous studies a description of the evolution of the Atlantic Moroccan passive margin and the Atlas Mountains areas has been done.

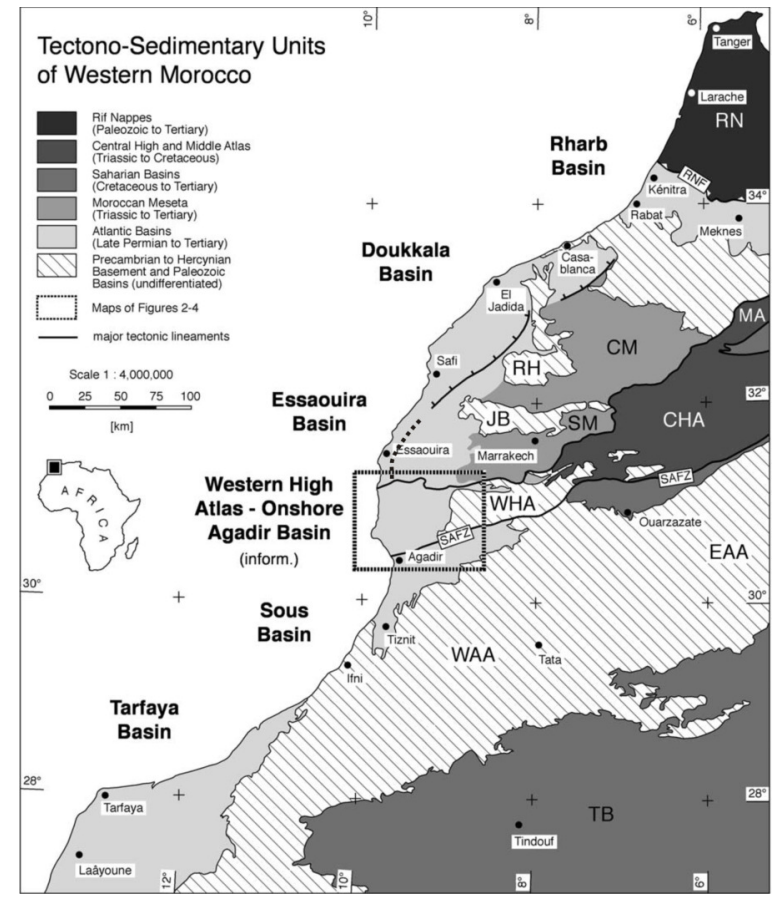

Figure 2: Major tectono-sedimentary units of western Morocco with Atlantic Basins (light grey, bold letters; from Zuhlke et al. (2003), based on Saadi (1982)). The box (thick broken line) indicates the onshore Agadir Basin. The dotted line indicates the seismic line as shown in figure 36 Legend: CHACentral High Atlas; CMCentral Meseta; EAAEastern Anti-Atlas; JBJebilet; MAMiddle High Atlas; RHRehamna; RNRif Nappes; RNFRif Nappe Front; SAFZSouth Atlas Fault Zone; SMsouthern Meseta; TBTindouf Basin; WAAwestern Anti-Atlas; WHAwestern High Atlas.

\subsection{Mid-Late Triassic-Early Liassic extension}

As stated by Le Roy and Piqué $(1998,2001)$ the geometry of the Moroccan marginal basins as a function of time shows a succession of half-grabens and horsts that migrated westwards partly reactivating Hercynian structures, see Figure 4. Pre-existing weakness zones enhanced the development of brittle deformation during pre-Carnian.

The Triasssic-Early Jurassic half-grabens of western Morocco formed on a peneplained basement consisting of NNE-SSW trending structures of Paleozoic sediments (Broughton and Trepanier, 1993). North and south of the Moroccan Atlantic margin the Triassic-Early Liassic normal faults which controlled the sinrift development are seen to trend $020^{\circ}$ and are compatible with WNW-ESE main extension direction. The half-grabens are linked and accommodated by $070^{\circ}$ sinistral transfer faults which seem to fade out westward. (Hafid, 2000; Tixeront, 1973; Medina, 1994, 1995). 
In the western High Atlas south of Essaouira, as well as in the Doukkala and Essaouira basins, fracturing in the onshore half-grabens developed as a result of extensive reactivation of the former limits of a Cambrian graben that had been folded during the Hercynian orogeny (Bernardin et al., 1988). Tayebi (1989) showed that the Triassic sinistral-normal faults developed under the structural control of Hercynian dextral-reverse faults, having a $070^{\circ}$ strike.

From the Mid-Late Triassic to the Early Liassic, the normal and transfer faults described above thinned the Western Moroccan crust. They represent a structural marker for Central Atlantic rifting, being contemporaneous with magmatic and thermal events (Piqué and Laville, 1996).

Successive episodes of rifting are defined through observations of synrift deposits and structure development in the western Moroccan basins.

The first of these episodes is the Middle Triassic NNW-SSE extension, that resulted in the development of ENE to WSW striking half-grabens (Hafid, 2000). In detail, from Carnian or even earlier, propagation was produced sequentially to develop the rift from the external rift domain, eastern onshore part of the Essaouira and Souss basins, towards the west and the north, resulting in the formation of the Central Atlantic rift (Figure 3). At the end of Carnian the nascent rift failed against the central rift domain that constituted a barrier preventing the transport of the extension. It is known that during the Carnian-Norian, the initial crustal extension strongly controlled by the reactivation of Palaeozoic structures was very limited compared to the subsequent episodes recorded in the western part of the basins during the Norian-Hettangian interval (LeRoy and Piqué, 2001).

Another episode is the Late Triassic to Early Liassic NW-SE extension, that was accompanied by basaltic extrusions and/or sills and caused the formation of westward dipping half-grabens (Hafid, 2000). During the Norian-Rhetian, basaltic-doleritic emplacement took place. Extension migrated to the west and the fracturing affected the southern Tarfaya margin and the western part of the Essaouira onshore basin. (LeRoy and Piqué, 2001).

Finally, a post-basaltic period between 210 and $195 \mathbf{M a}$ (Ras, 1992; Schaltegger et al., 1994) was characterized by an abnormal thermal regime, probably related to hydrothermal metamorphic activity. Rift activity proceeded toward the inner axial part and borders began to subside, brittle extension proceeded northward through the Doukkala Basin and affected the entire margin during the Rhetian?-Hettangian period. At the end of this episode, brittle extension ceased in the Essaouira and Tarfaya basins. However, the Liassic marine transgression did not affect the Doukkala Basin, which was submitted to major uplift and subsequent erosion (LeRoy and Piqué, 2001).

Figure 3: Paleo-geographic map of the world in the Early Jurassic, by C. R. Scotese.

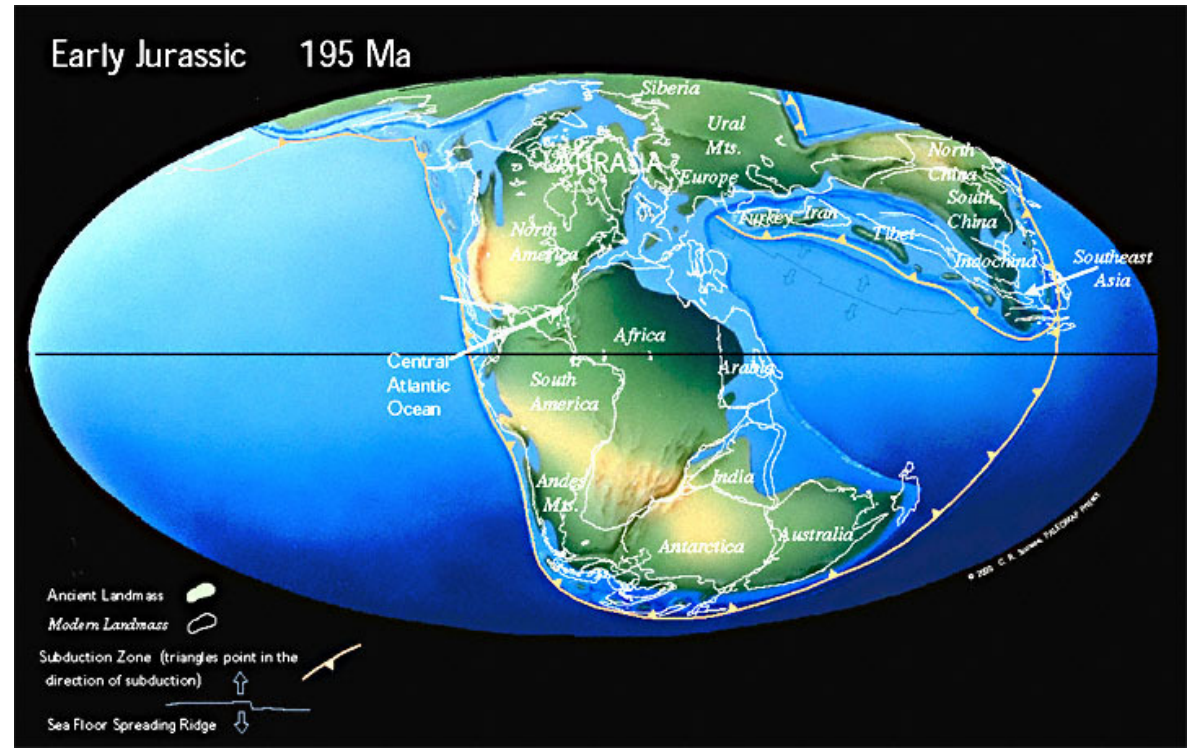




\subsection{Late Jurassic to Cretaceous deformation}

In the Liassic, when the extension which formed the Atlas (Tethyan) rifts and the Atlantic margin had already ended, only postrift subsidence was occurring in these domains (Medina, 1995; Le Roy and Piqué, 2001; Ellouz et al., 2003). During this postrift stage thermal relaxation dominated, and the three fast subsidence periods mentioned by Medina (1995) occurred. Those periods of fast subsidence can be easily correlated with episodes of faulting and increased spreading rates of the Atlantic rift (Medina, 1995). Continued minor tectonic activity associated mostly with northwest-southeast trending faults persisted during Jurassic and Cretaceous as is suggested by thickness changes and structural growth across anticlines associated with these faults (Hafid, $2000)$.

The erosion/exhumation shown by fission track and (U-Th)/He data documented by Ghorbal (2008) within the Moroccan Meseta, discard the general idea that NW Africa was slightly-subsiding during Early Cretaceous or experienced a stable evolution since the end of the Hercynian orogeny, as commented by (Michard et al., 1989; Guiraud et al., 2005 and many others). Subsidence coeval to Atlantic rifting affected an area much larger than previously expected, including the Meseta and the Atlas system. During the postrift stage, exhumation affected a several hundreds Km, elongated in NNE-SSW direction area. The Moroccan Meseta subsided to $>3 \mathrm{Km}$ depth during the Early to Middle Jurassic and was then exhumed to the Earth's surface during the Late Jurassic (Ghorbal, 2008). The Amsittene anticline might also have formed during this period. In contrast to the Moroccan Meseta, the Essaouira basin did not experience any uplift, but only gradual subsidence during the Jurassic and Lower Cretaceous (Le Roy and Piqué, 2001). The Late Jurassic - Early Cretaceous deformation in the Essaouira Basin is still poorly understood. Thickness variations in Late Jurassic and Early Cretaceous sediments and related syn-depositional faults affecting the Jurassic are explained by (Medina, 1994, 1995) to poorly constrained N-S to NE-SW direction of extension. In the Essaouira Basin the first postrift deposits are Sinemurian in age, 197 Ma (Duffaud 1960; Bouaouda 1987; Peybernés et al. 1987)(Figure 4).

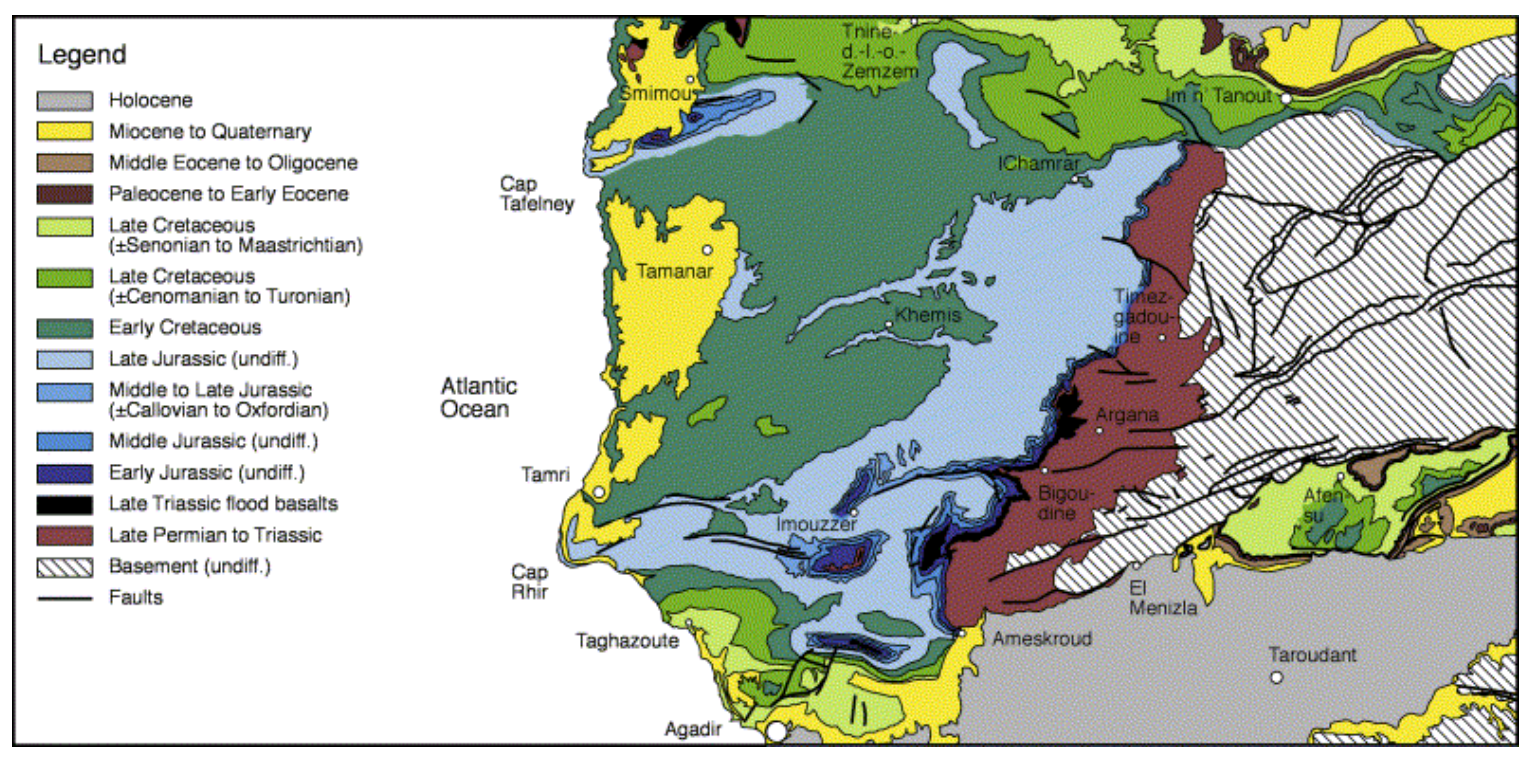

Figure 4: Geological map of the western High Atlas (inverted Agadir continental margin basin), the southern part of the Essaouira Basin and the northern part of the Souss Basin.

Simplified after Jadi, Bencheqroun, and Diouri (1970a,b), Ouzzani, Eyssautier, Marcais, Choubert and Fallot (1956), and Saadi (1982). From R. Zuhlke et al, 2004.

\subsection{Late Cretaceous to recent compression}

At the end of the Mesozoic the convergence of Africa with Europe began, causing inversion of Mesozoic rift systems. This leads to the formation of the Atlas mountains (Stets and Wurster, 1982, 1983; Laville and Petit, 1984; Laville, 1987; Jacobshagen Go and Giese, 1988; Brede, Hauptmann and Herbig, 1992, Giese and Jacobshagen, 1992; Zizi, 1996a,b, Frizon de Lamotte et al, 2000), which is still an active orogeny. 
Compressionally reactivated synrift normal faults are responsible for the inverted structures, which clearly involved the pre-Mesozoic basement (Gabor C. and M. Zizi, 1996). During the Tertiary overall NNW to SSEoriented compression caused the inversion of NE and NNE-striking structures and/or the formation of salt anticlines. This compression, associated with formation of the Western High Atlas, led to the individualisation of EW striking anticlines and reverse faults suggesting the reactivation of late Triassic-Early Liassic transfer faults (Hafid, 2000).

The roughly EW-striking High Atlas and the NE-striking Middle Atlas Mountains of Morocco are often interpreted as late Cretaceous to Neogene inversions of Triassic to lower Jurassic extensional systems (Stets and Wurster, 1982, 1983; Laville and Petit, 1984; Laville, 1987; Jacobshagen Go and Giese, 1988; Brede, Hauptmann and Herbig, 1992, Giese and Jacobshagen, 1992; Zizi, 1996a,b).

The first significant stages of a building topography in the Rif and Atlas mountains are Oligocene or younger (e.g. Frizon de Lamotte et al., 2000; Chalouan et al., 2001). Late Cretaceous to Tertiary subsidence affected the Moroccan Meseta. About $1 \mathrm{Km}$ of subsidence affected the Meseta during the Paleogene. Later, during the Neogene, the meseta exhumed, as a result of bimodal folding. Folding with wavelengths of $80-100 \mathrm{Km}$ caused the formation of Rehamna and Rommani anticlines, separated by the Settat syncline. Larger scale folding with $>400 \mathrm{Km}$ wavelengths raised the entire area above sea level. Folding was coeval with intense localized shortening at the northern and southern sides of the Moroccan Meseta leading to the formation of the Atlas and Rif fold-and-thrust belts (Ghorbal, 2008).

The Atlas build up occurred everywhere during two main phases of respectively Late Eocene and PleistoceneEarly Quaternary age. These phases are clearly distinct and do not represent end points of a progressive deformation (Frizon de Lamotte et al, 2000). They correspond roughly to the initiation and the cessation of the subduction of the Maghrebian Tethys and the related formation of the Tell-Rif accretionary prism.

Probably because of different mechanical coupling between the Tell-Rif wedge and its foreland (Ziegler et al., 1998), the orogenic systems of North Africa undergo the following development (Frizon de Lamotte et al, 2000): (i) the deformation has been initiated within the most external part of the system (i.e., within the Atlas), (ii) the kinematics of the Atlas (foreland) is not in direct relation with the translations observed in the Tell-Rif (hinterland), (iii) the present-day activity is concentrated along an out-of-sequence thrust zone coming from the Atlantic Ocean and cutting across the previously emplaced Tell-Rif. Frizon de Lamotte et al. (2000) link the geometry of the Rif-Tell accretionary system to the geometry of the subduction responsible for its formation. The directions of translations observed in this system are not directly related to the relative convergence of Africa with respect to Europe. Moreover, the velocity of translations within the Rif system is five times greater than the velocity of the convergence. By contrast, the Atlas remains insensitive to subduction processes active in the western Mediterranean region but has faithfully recorded the main jolts and the direction of the Europe-Africa convergence. Since the lower Quaternary, the northward motion of Africa is accommodated by shortening concentrated along the Tell-Rif margin, but affecting diffusedly the whole western Mediterranean region from the South Atlas Front to the Pyrenean thrust system (Vergds and Sebat, 1999).

\subsection{Stratigraphy}

In the Jbel Amsittene region, Late Triassic to Quaternary rocks are exposed. The stratigraphy is based on the geological map of Tamanar made by the Moroccan Geological Survey in the seventies. The chronostratigraphy is based on Duffaud et al. (1966) and Zühlke et al. (2004) for the Agadir Basin, app. 100Km south of the Jbel Amsittene anticline. See for the thicknesses and ages of the different formations the simplified chronostratigraphic column (Table 1).

The oldest exposed formation is the Argiles rouges d'Argana (T5), 215-204 Ma, and consists of deltaic sandstones interbedded with some halite and evaporites, see Figure 5. In addition, some loose Upper Triassic basalt blocks have been observed in this formation. From 204-191 Ma there is a depositional and erosional gap; within this gap there is the Dolomies récifales $\left(I_{4}-6\right)$, which exact age is unknown. From the Toarcian until the end of the Middle Jurassic there is a slow transition from a floodplain to an inner shelf environment. Sediments change from predominantly siliciclastic sand to carbonate shallow marine deposits. In the Late Jurassic there are mainly carbonate shallow marine deposits in an inner shelf to a lagoon environment.

Environmental changes from an inner shelf to an outer shelf occurred by the end of the Albian stage (during the Early-Middle Cretaceous). The sedimentary strata consists of massive limestone and marls (Figure 6).

On top of Upper Cretaceous and Tertiary rocks the Quaternary terrestrial colluviums and coastal deposits are located, see Figure 7. 


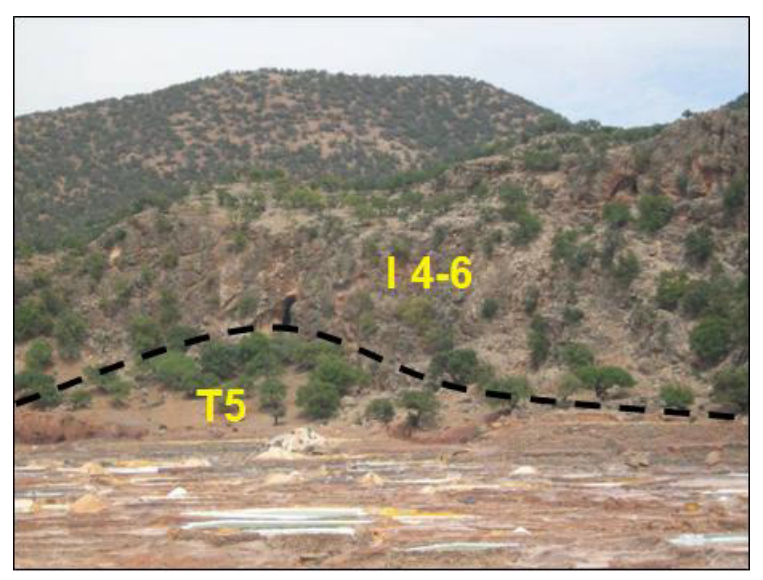

Figure 5: Up-doming of the I4-6 Formation above the T5 Formation in the salt mine.

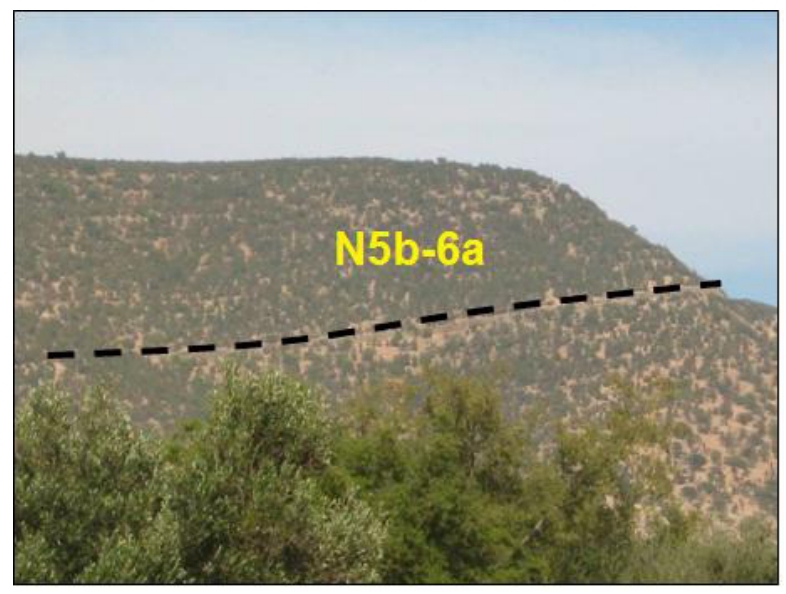

Figure 6: Cretaceous sediments on the south flank of the Neknafa syncline, north of the Jbel Amsittene anticline.

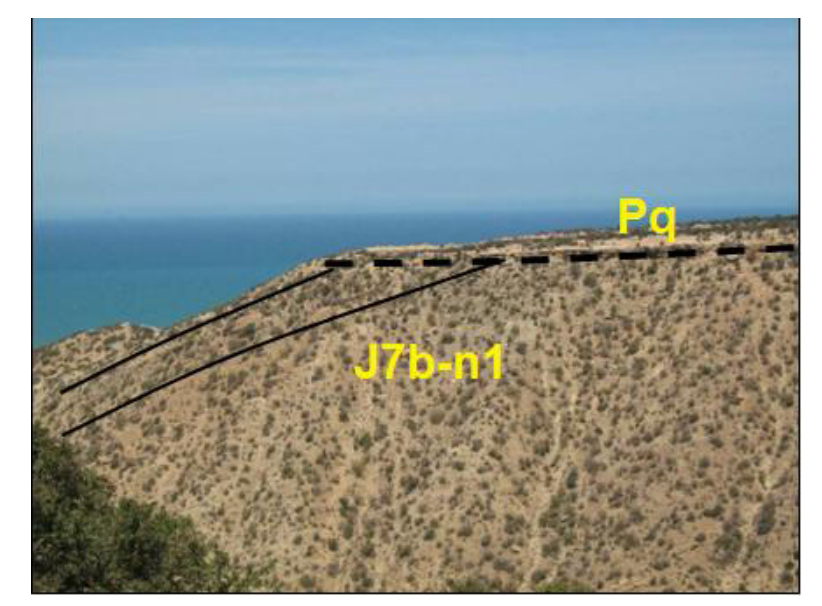

Figure 7: Discordant contact between the older J7b-n1 Formation and younger Quaternary deposits in the most western part of the Jbel Amsittene. 


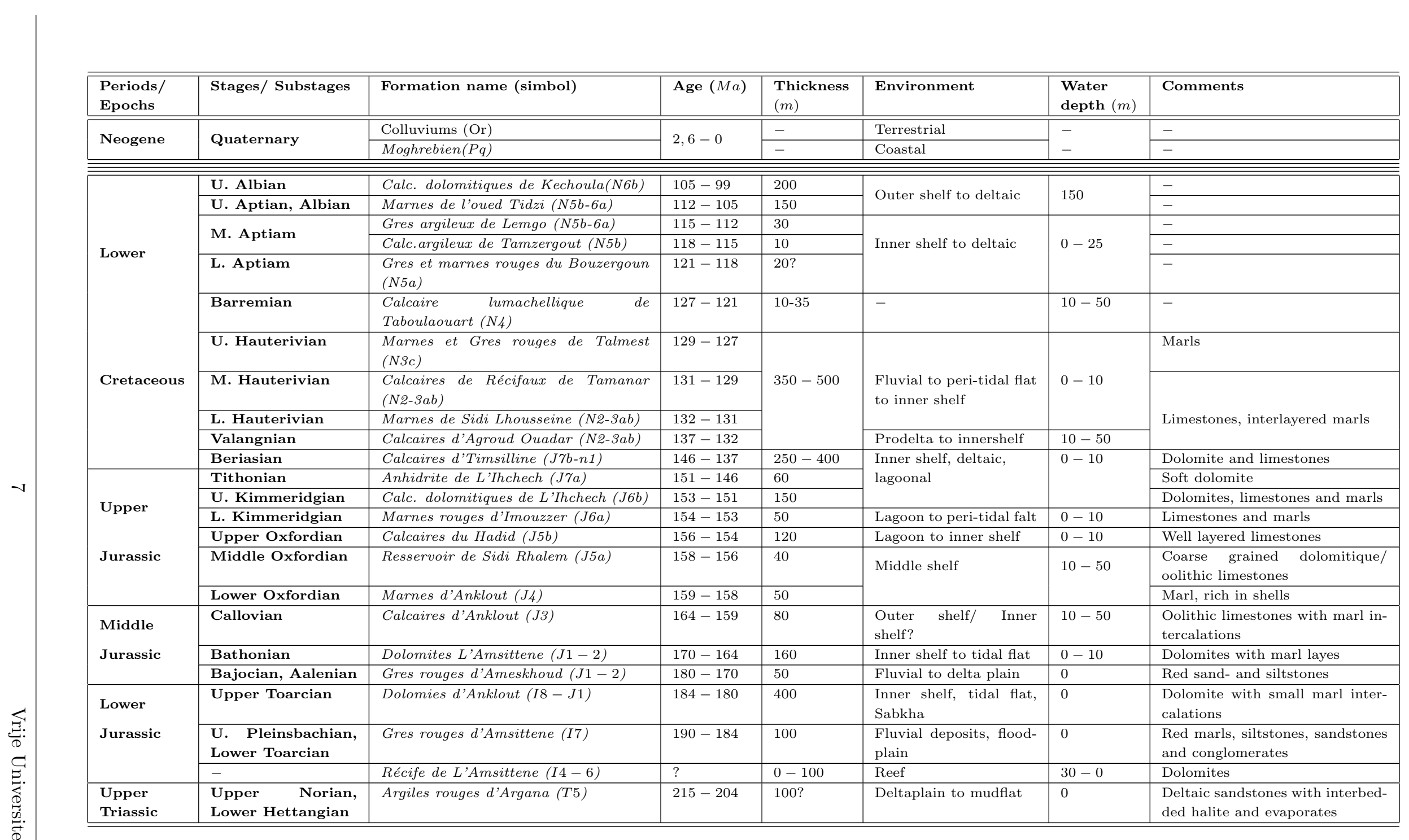


Based on the environments a water-depth curve is estimated and in combination with the sedimentary thicknesses a subsidence curve has been constructed, see Figure 8.The curve is not corrected for compaction

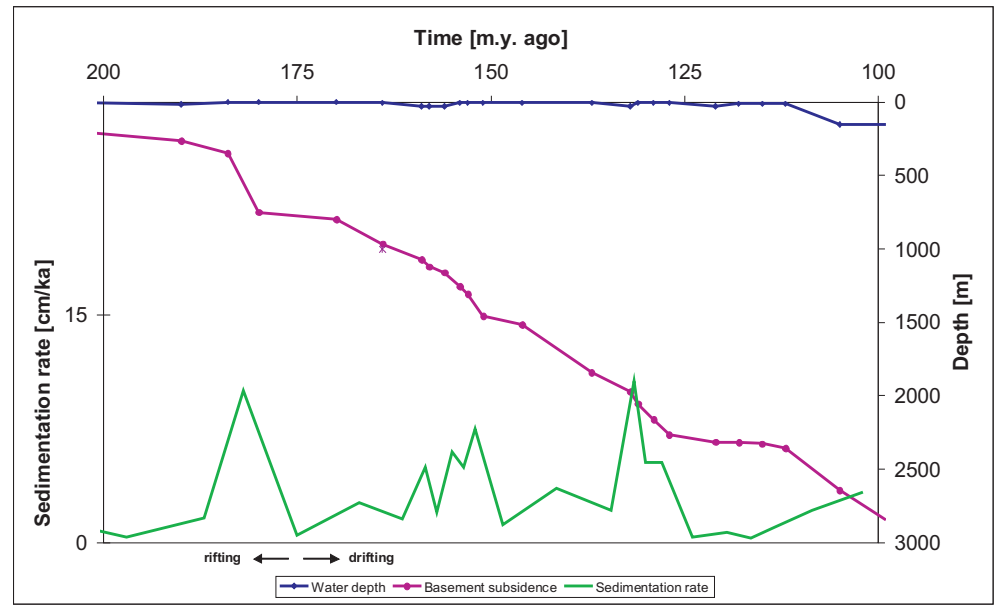

Figure 8: Subsidence curve and sedimentation rate of the sediments from the Jbel Amsittene anticline area.

Figure 8 shows three periods of high subsidence rate; $184-180$ Ma, $156-151$ Ma and $132-127$ Ma. There is a clear drop in subsidence from $180-170 \mathrm{Ma}$ and from $127-115 \mathrm{Ma}$. 


\section{Outcrops}

In this chapter we discuss the most important outcrops in the field area that have been used to constrain the geological evolution of the area. The locations of the outcrops can be found in Figure 9.

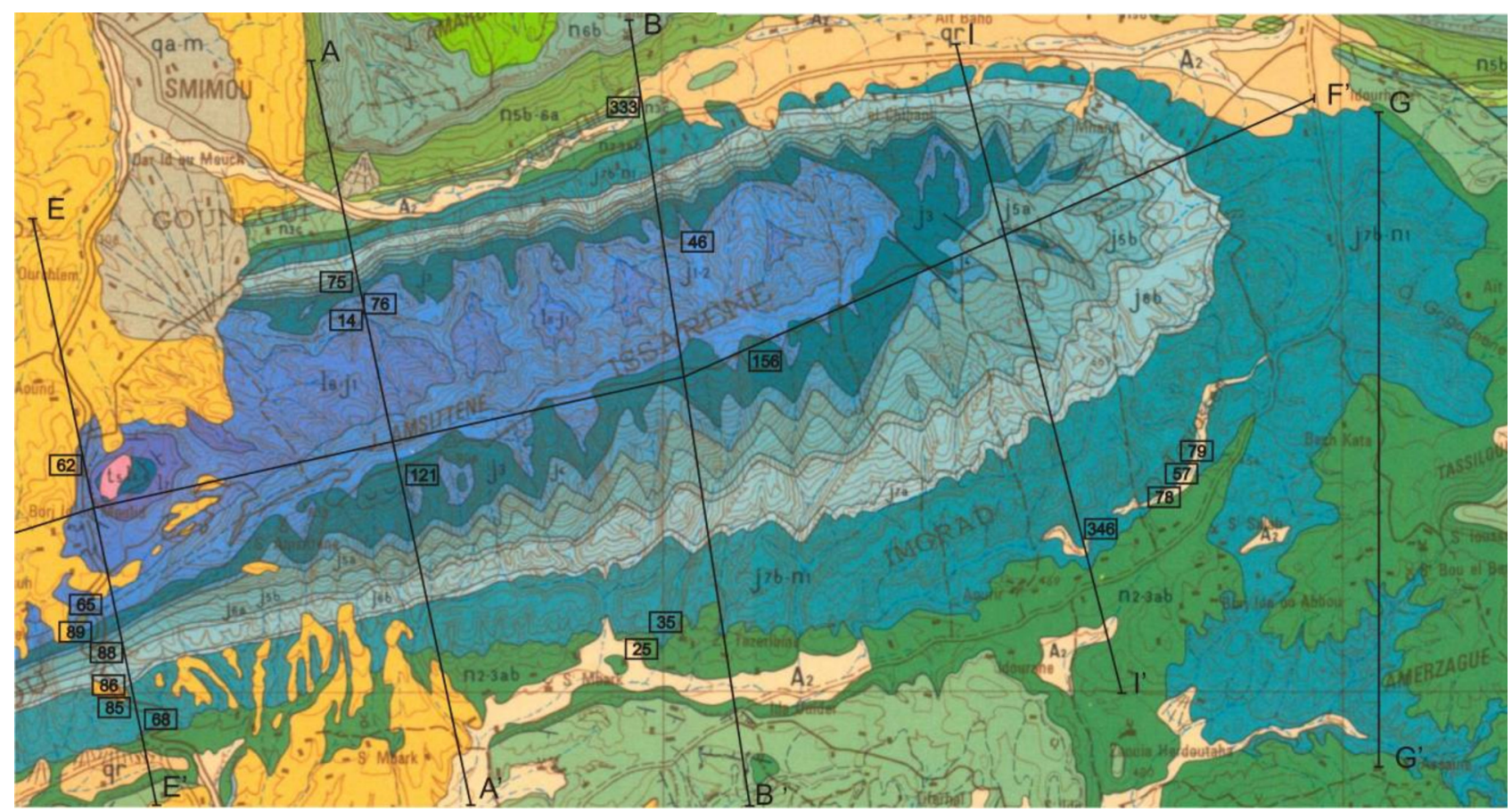

Figure 9: Location of all the outcrops mentioned in the text.

\subsection{Outcrops near profile $E-E^{\prime}$}

Profile $E-E^{\prime}$ is along the road from Essaouira to Agadir and provides a good cross sectional overview on the anticline (Figure 10). Due to the road cuts the quality and accessibility of the outcrops was very good.

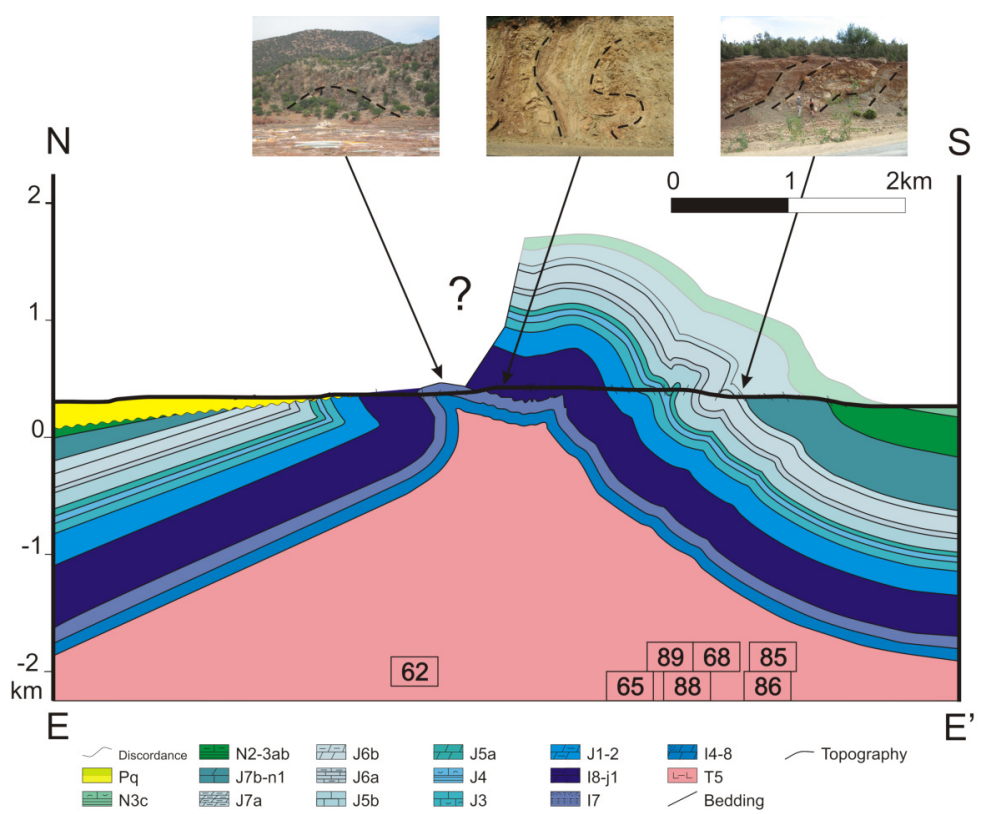

Figure 10: Positions of all the outcrops mentioned in the text along profile $E-E^{\prime}$. 


\subsubsection{Outcrop $n^{e r} 62$}

- Location: $\mathbf{X}=432461 ; \mathbf{Y}=3447449 ; \mathbf{Z}=415$

- Formation: I8-J1, Dolomies d'Anklout.

- Lithology: Limestone with marl intercalations.

- Description: Limestone with folds and reverse faults. The thickness of the limestone layers varies. The folds have a fold axis of 234/14 and an axial plane of 149/70.

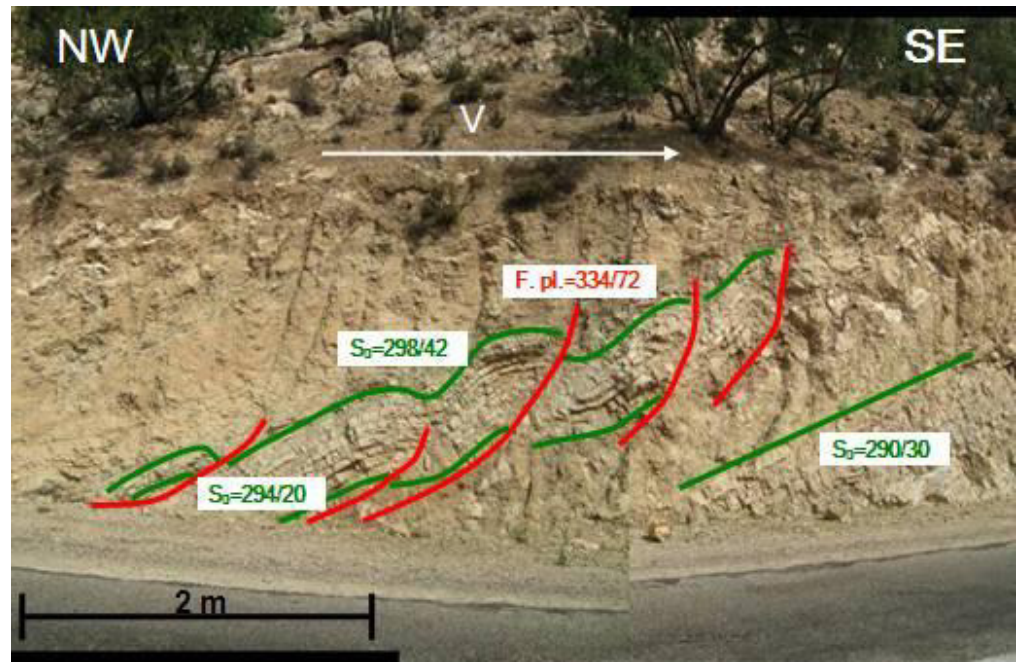

Figure 11: Outcrop $n^{e r} 62$

- Interpretation: The reverse faults and folds have southeastern vergence. The orientation of the fault planes and the axial planes of the folds are similar and indicate 150-330 oriented shortening. This outcrop is situated close to the outcropping salt (Figure 9); is less than 200 meters east of this outcrop. The strata in this outcrop are however not affected by halokinesis, but compressional deformation.

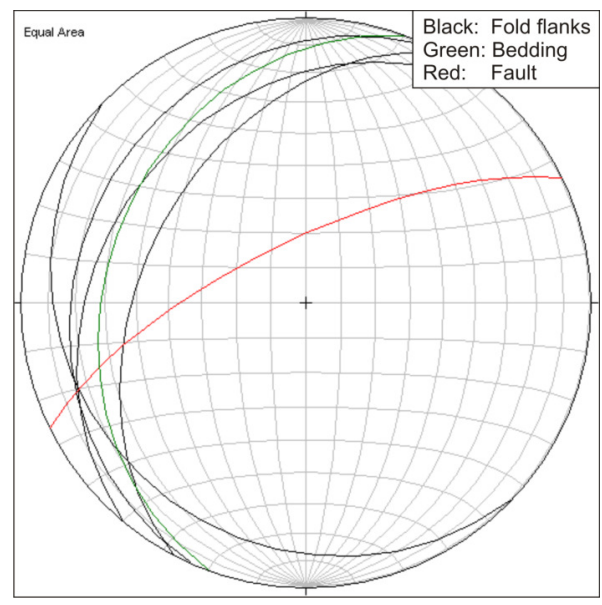

Figure 12: Stereoplot of fault and fold flanks. 


\subsubsection{Outcrop $n^{e r} 65$}

- Location: $\mathbf{X}=432595 ; \mathbf{Y}=3446120 ; \mathbf{Z}=452$

- Formation: J1-2, Dolomies de l'Amsittne.

- Lithology: Grainstone.

- Description: Well lithified grainstone with interlayered marl and mud. Several ramp fold systems.

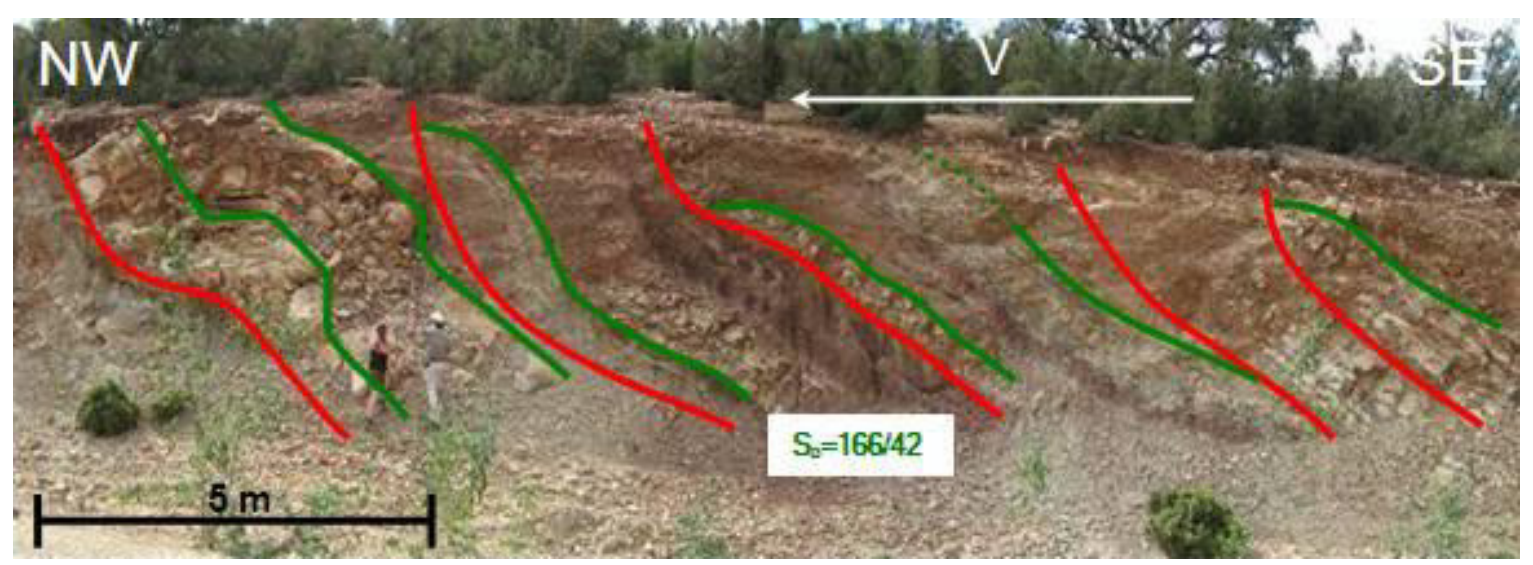

Figure 13: Outcrop $n^{\text {er }} 65$

- Interpretation: Ramp fold system indicating top to the north shortening. In the most northwestern part a kink fold has developed.

\subsubsection{Outcrops $n^{e r} 88$ and 89}

- Location 88: $\mathbf{X}=432534 ; \mathbf{Y}=3445620 ; \mathbf{Z}=426$

- Location 89: $\mathbf{X}=432546 ; \mathbf{Y}=3445764 ; \mathbf{Z}=426$

- Formation: J3, Calcaires d'Anklout.

- Lithology: Limestone.

- Description: Two outcrops that are 30 meters apart from each other. They both show fault planes parallel to the bedding. The dip direction of the two faults and striations are juxtaposed.

Table 2: Orientations of the fault planes and their specific striations at outcrop 88 and 89 .

\begin{tabular}{|c|c|c|}
\hline & Outcrop $n^{e r} \mathbf{8 8 ,}$, south & Outcrop $n^{e r} \mathbf{8 9}$, north \\
\hline$S_{0} / S_{1}$ & $340 / 64$ & $170 / 85$ \\
\hline Striations & $355 / 62$ & $171 / 85$ \\
\hline
\end{tabular}




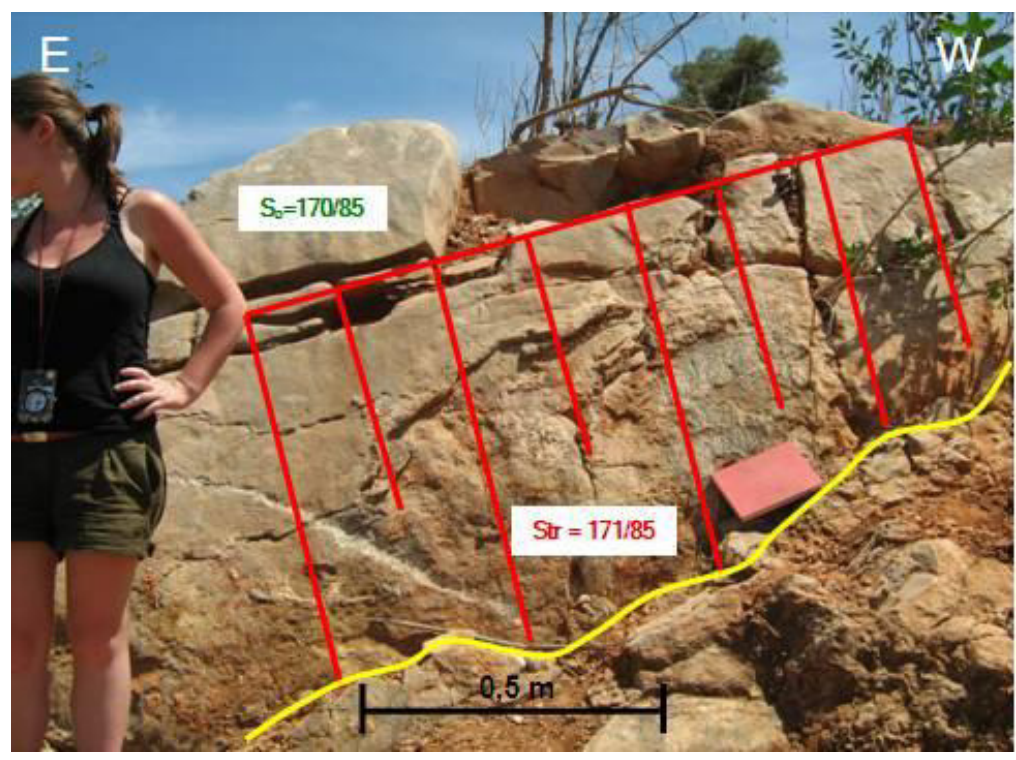

Figure 14: Outcrop $n^{\text {er }} 89$

- Interpretation: The two faults are a result of flexural slip folding. The direction of maximum shortening is $65-345^{\circ}$.

\subsubsection{Outcrop $n^{e r} 85$}

- Location: $\mathbf{X}=432914 ; \mathbf{Y}=3444933 ; \mathbf{Z}=378$

- Formation: J7b-n1, Calcaires de Timsilline.

- Lithology: Limestone, marl and mud.

- Description: The strata are cut by a neptunian dyke with a current position of 272/83.

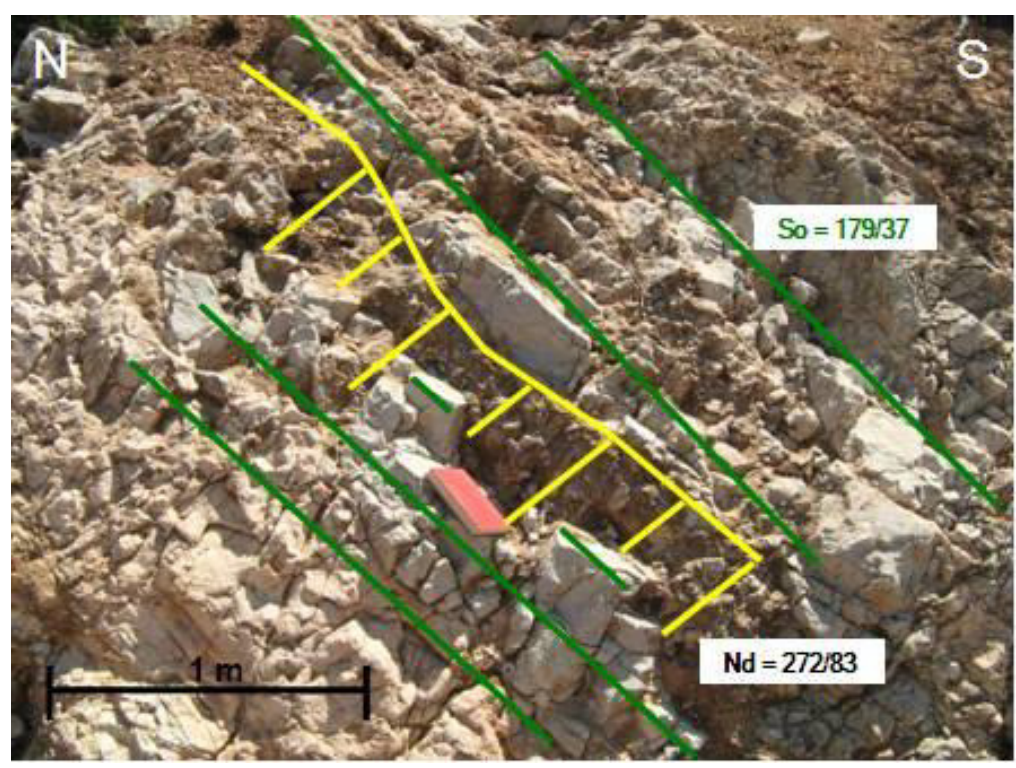

Figure 15: Outcrop $n^{\text {er }} 85$

- Interpretation: The neptunian dyke is not completely vertical. Assuming that the neptunian dyke was formed vertically, the bedding of the limestone in which it formed was subhorizontal (Figure 16). The position of the neptunian dyke is an indicator for east-west extension. 


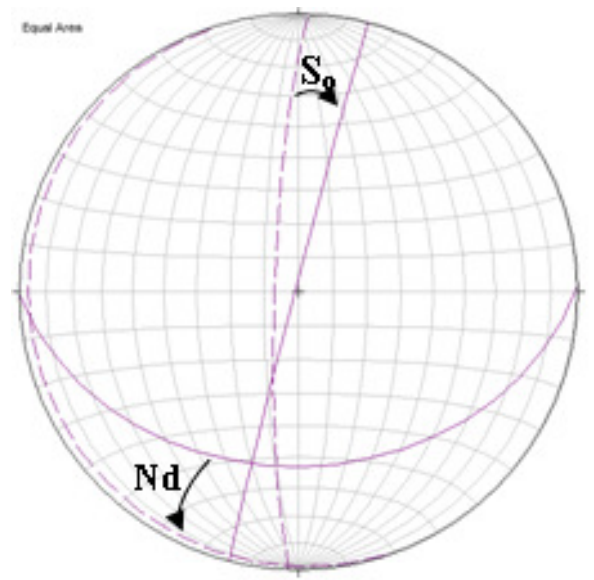

Figure 16: Stereoplot of the neptunian dyke and bedding. The arrows show the orientation of the neptunian dyke and bedding at time of formation of the dyke.

\subsubsection{Outcrop $n^{e r} 86$}

- Location: $\mathbf{X}=432914 ; \mathbf{Y}=3444975 ; \mathbf{Z}=376$

- Formation: J7b-n1, Calcaires de Timsilline.

- Lithology: Limestone.

- Description: Folded and faulted soft sediments.

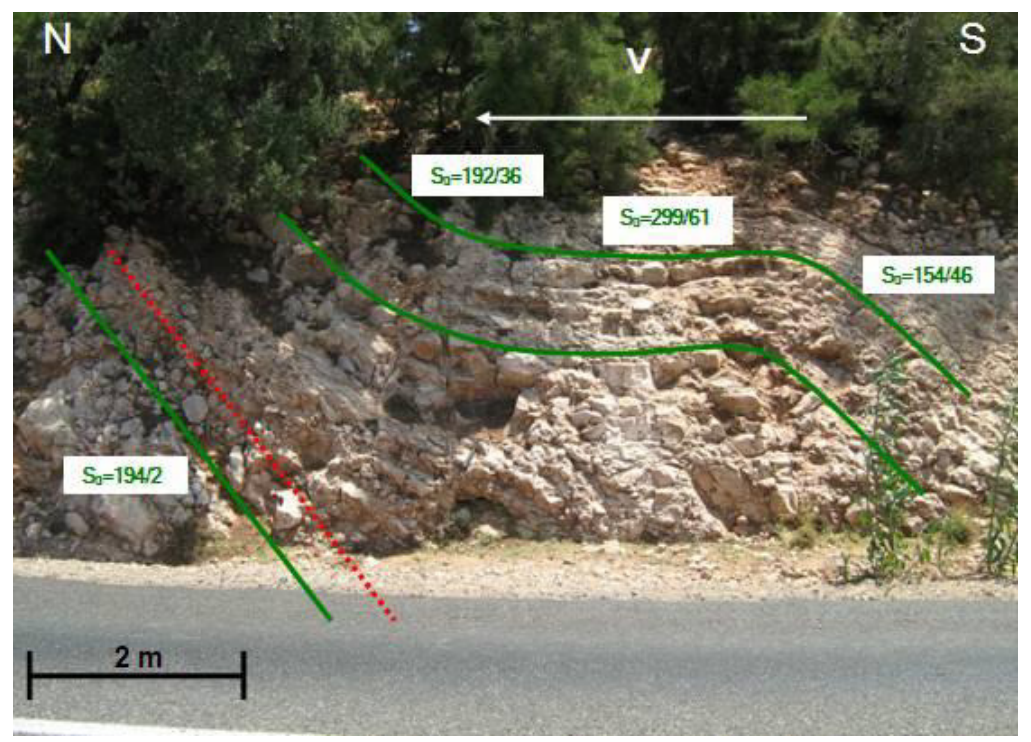

Figure 17: Outcrop $n^{e r} 86$

- Interpretation: This structure can represent a slump or a syn-sedimentary ramp fold. The northern vergence of the structure favors a ramp fold. If this is true, the timing of the deformation is $144-150 \mathrm{Ma}$ (Late Jurassic). The shortening direction is 160-340 (Figure 18). 


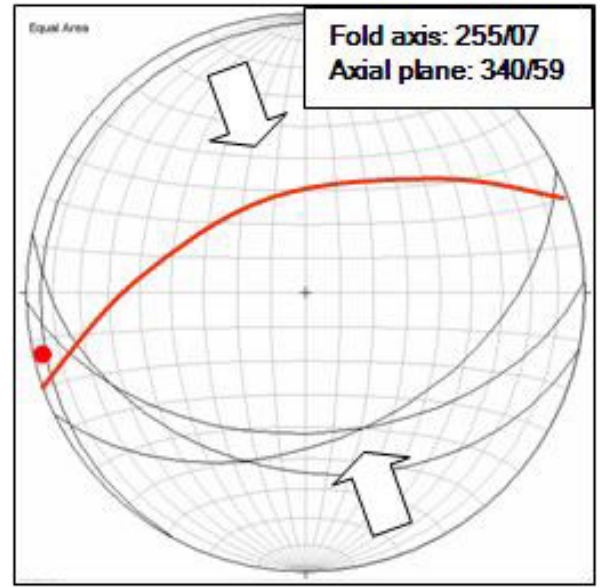

Figure 18: Stereoplot of the syn-sedimentary ramp fold with the fold axis and axial plane indicating a north-northwest to south-southeast shortening during the Late Jurassic.

\subsubsection{Outcrop $n^{e r} 68$}

- Location: $\mathbf{X}=433150 ; \mathbf{Y}=3444534 ; \mathbf{Z}=335$

- Formation: N2-3ab, Calcaires de Récifaux de Tamanar, Marnes de Sidi Lhousseine and Calcaires d'Agroud Ouadar.

- Lithology: Limestone.

- Description: Slightly tilted bedding with several similar conjugate sets.

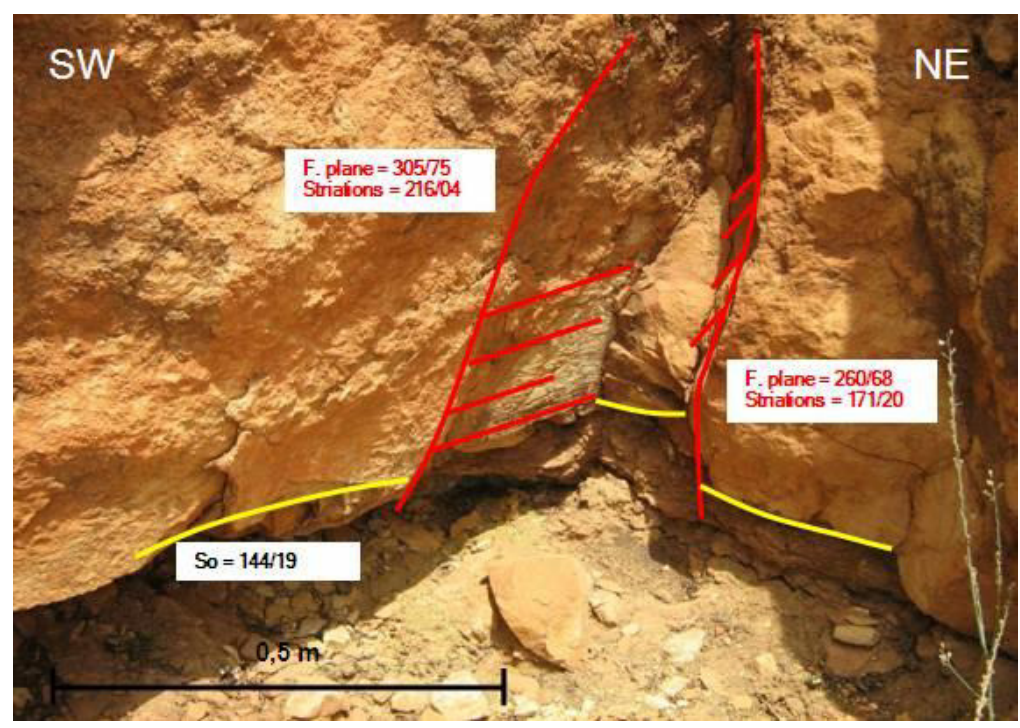

Figure 19: Outcrop $n^{e r} 68$ 
- Interpretation: The three conjugate sets, show similar stress orientations; maximum horizontal stress is $\mathrm{N}-\mathrm{S}$ to NNE-SSW, see the stereoplots in Figure 20.
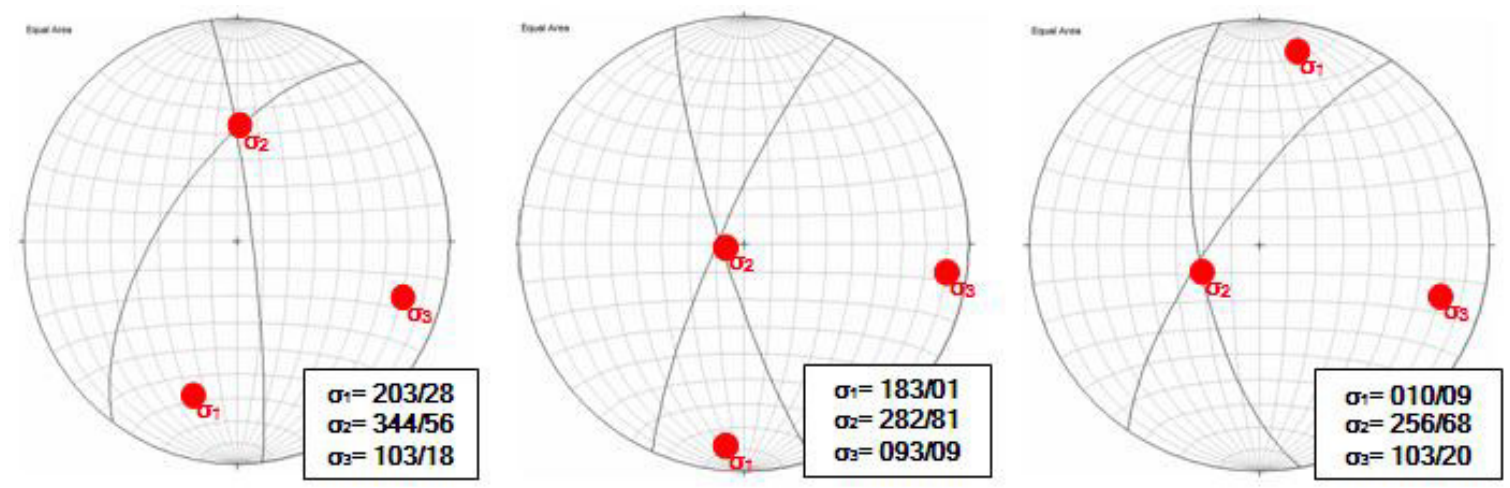

Figure 20: Stress directions of all the conjugate sets at outcrop 68 indicating a north to south to north-northeast to south-southwest shortening.

We can rotate the data with respect to the bedding to determinate the orientation of the conjugate sets before tilting and the corresponding stress directions. The data are plotted in Table 3.

Table 3: Stress orientations of all the conjugate sets at outcrop $n^{e r} 68$.

\begin{tabular}{lcccrr}
\multirow{2}{*}{ Bedding } & Present orientation & Orientation before tilting & \multirow{2}{*}{ Quality } & \multirow{2}{*}{ Formation } \\
\cline { 2 - 4 } & $\sigma_{1}-\sigma_{2}-\sigma_{3}$ & $\sigma_{1}{ }^{\prime}-\sigma_{2}{ }^{\prime}-\sigma_{3}{ }^{\prime}$ & & & \\
\hline $144 / 19$ & $010 / 09-256 / 68-103 / 20$ & $014 / 22-208 / 67-106 / 02$ & Very Good & J7b-n1 \\
$146 / 28$ & $203 / 28-344 / 56-103 / 18$ & $195 / 11-031 / 79-286 / 03$ & Good & J7b-n1 \\
$144 / 19$ & $183 / 01-282 / 81-093 / 09$ & $005 / 13-171 / 76-274 / 03$ & Good & J7b-n1
\end{tabular}

These data show an approximately maximum horizontal stress of NNE-SSW, in both non-rotated and rotated sets.

\subsection{Outcrops near profile $A-A^{\prime}$}

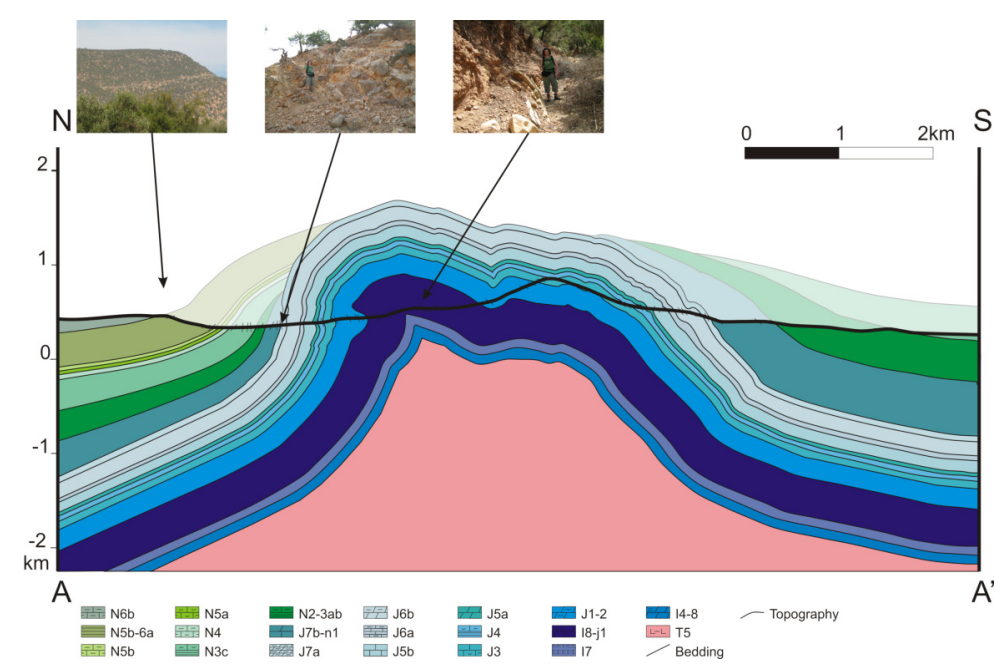

Figure 21: Positions of all the outcrops mentioned in the text along profile $A-A^{\prime}$. 


\subsubsection{Outcrop $n^{e r} 14$}

- Location: $\mathbf{X}=436116 ; \mathbf{Y}=3449869 ; \mathbf{Z}=424$

- Formation: J1-2, Dolomies de l'Amsitine.

- Lithology: Grainstone.

- Description: Underthrust in overturned strata, $S_{0}$ is $175 / 73$.

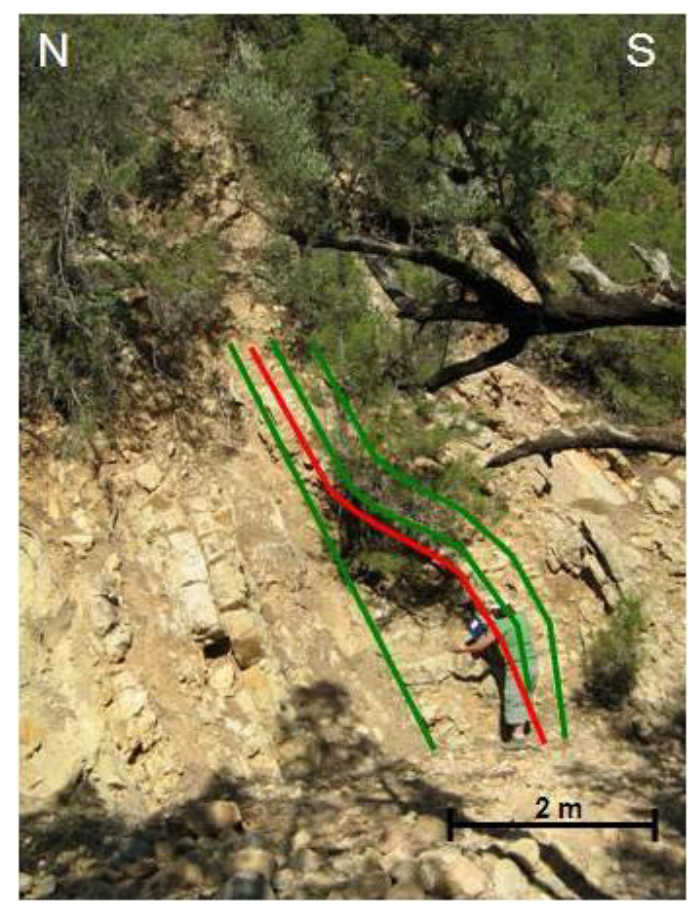

Figure 22: Outcrop $n^{e r} 14$

- Interpretation: Fault-bend fold, with top to the south movement. The fold in the hanging wall has a fold axis of 085/06 and axial plane of 022/14.

\subsubsection{Outcrop $n^{\text {er }} 75$}

- Location: $\mathbf{X}=435879 ; \mathbf{Y}=3450277 ; \mathbf{Z}=376$

- Formation: J5b, Calcaires du Hadid.

- Lithology: Limestone.

- Description: Inclined layers are cut by neptunian dykes, $S_{0}$ is $174 / 76$. The orientation of the neptunian dyke is $303 / 82$. 


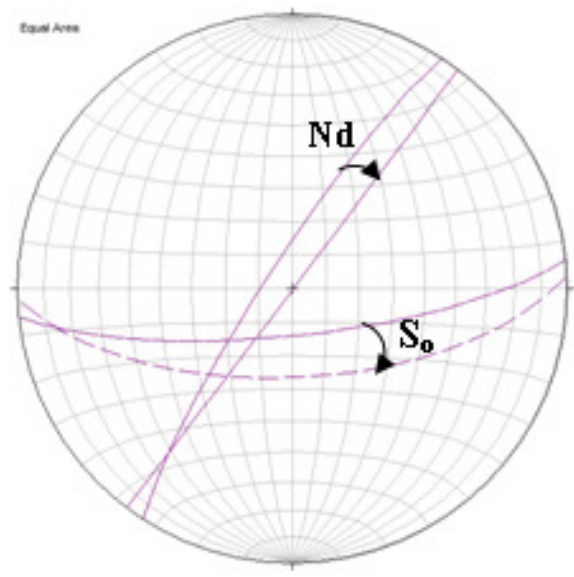

Figure 23: Stereoplot of the neptunian dyke and bedding. The arrows show the orientation of the neptunian dyke and bedding at time of formation of the dyke.

- Interpretation: The neptunian dyke is not completely vertical. Assuming that the neptunian dyke was formed vertically, the bedding of the limestone in which it formed was dipping $65^{\circ}$ towards the south (Figure 23). The position of the neptunian dyke is an indicator for northwest-southeast extension.

\subsubsection{Outcrop $n^{e r} 121$}

- Location: $\mathbf{X}=436722 ; \mathbf{Y}=3447634 ; \mathbf{Z}=725$

- Formation: J3, Calcaires d'Anklout.

- Lithology: Limestone.

- Description: Inclined layers are cut by a neptunian dyke, $S_{0}$ is $183 / 35$. The orientation of the neptunian dyke is $065 / 60$.

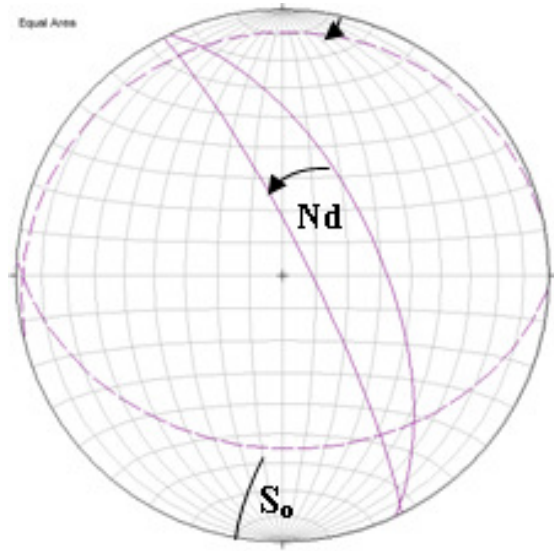

Figure 24: Stereoplot of the neptunian dyke and bedding. The arrows show the orientation of the neptunian dyke and bedding at time of formation of the dyke.

- Interpretation: The neptunian dyke is not completely vertical. Assuming that the neptunian dyke was formed vertically, the bedding of the limestone in which it formed was dipping $10^{\circ}$ to $20^{\circ}$ towards the north (Figure 24). The position of the neptunian dyke is an indicator for westsouthwest-eastnortheast extension. 


\subsubsection{Interpretation and conclusions for the neptunian dykes}

A neptunian dyke is a strong indication of an extensional regime. It forms in the uppermost sediments of the seafloor. It is striking that we find the dykes in different formations. The total time span along the deposition of these formations is $23 \mathrm{Ma}$; from 146 until $159 \mathrm{Ma}$. The neptunian dykes indicate different extension orientations. They may indicate an northwest-southeast to westsouthwest-eastnortheast extension (Figure 25). At time of formation of the neptunian dykes, the orientation of the bedding of the sea floor was different for each dyke. This can be explained by either spatial differences of the bedding, or by the time gaps between the formation of the three dykes.

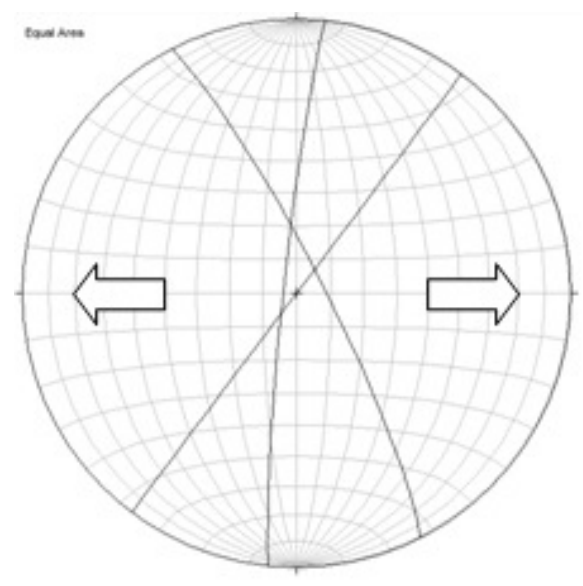

Figure 25: The approximate orientation of the three dykes at time of their formation

\subsection{Outcrops near profile $B-B^{\prime}$}

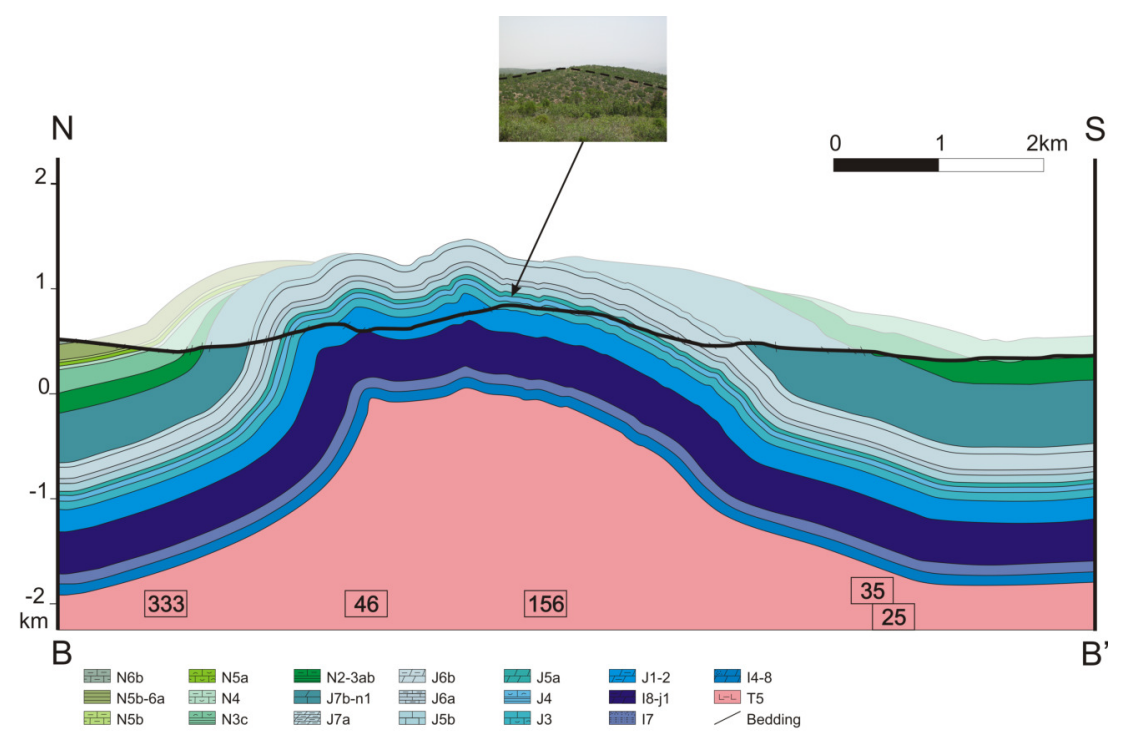

Figure 26: Positions of all the outcrops mentioned in the text along profile $B-B^{\prime}$. 


\subsubsection{Outcrop $n^{e r} 46$}

- Location: $\mathbf{X}=440332 ; \mathbf{Y}=3450708 ; \mathbf{Z}=739$

- Formation: J1-2, Dolomies de l'Amsitine.

- Lithology: Limestone.

- Description: Outcrop with three different orientated stylolites.

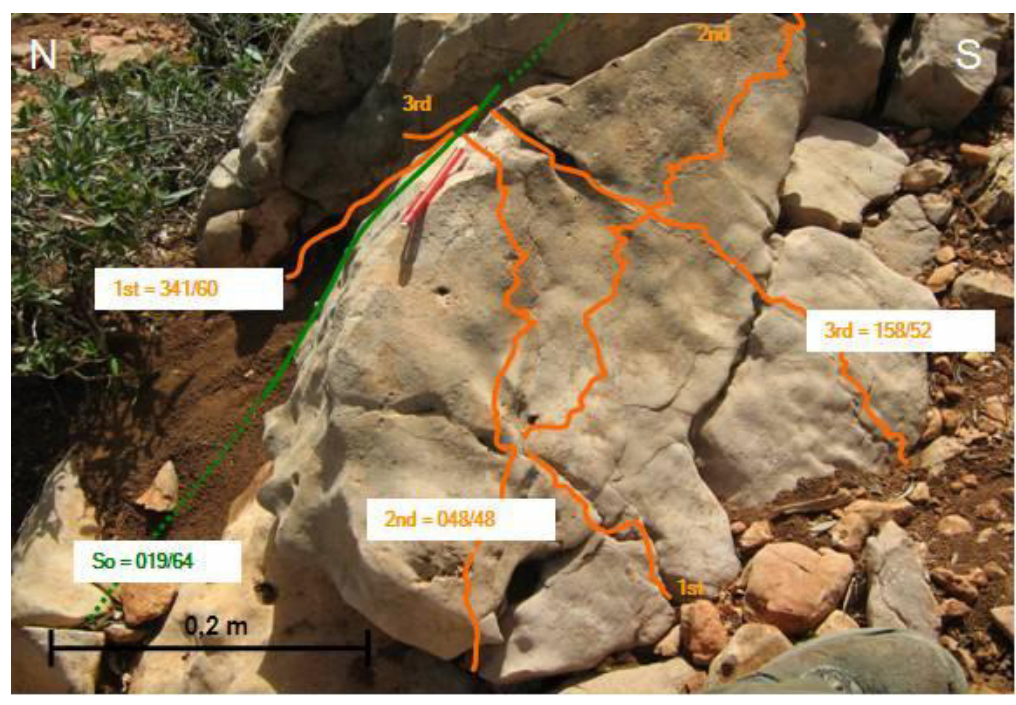

Figure 27: Outcrop $n^{e r} 46$

- Interpretation: The teeth of the stylolites indicate different stress fields (Table 4). However, when one calculates the direction of the teeth before the strata were tilted, the teeth show some similarity indicating a $\mathrm{NW}-\mathrm{SE}$ to $\mathrm{N}-\mathrm{S}$ shortening.

Table 4: Orientations of the stylolites before and after tilting at outcrop $n^{e r} 46$.

\begin{tabular}{lllrr} 
Stylolites & Bedding & $\begin{array}{l}\text { Present orientation } \\
\text { stylolite surface }\end{array}$ & Teeth & Teeth before tilting \\
\hline $1^{\text {st }}$ & $019 / 64$ & $341 / 60$ & $333 / 20$ & $150 / 26$ \\
$2^{\text {nd }}$ & $019 / 64$ & $048 / 48$ & $215 / 49$ & $323 / 23$ \\
$3^{\text {rd }}$ & $019 / 64$ & $158 / 52$ & $280 / 40$ & $355 / 64$
\end{tabular}

\subsubsection{Outcrop $n^{e r} \mathbf{1 5 6}$}

- Location: $\mathbf{X}=441189 ; \mathbf{Y}=3449200 ; \mathbf{Z}=846$

- Formation: J3, Calcaires d'Anklout.

- Lithology: Limestone. 
- Description: Calcite shear zone fractures.

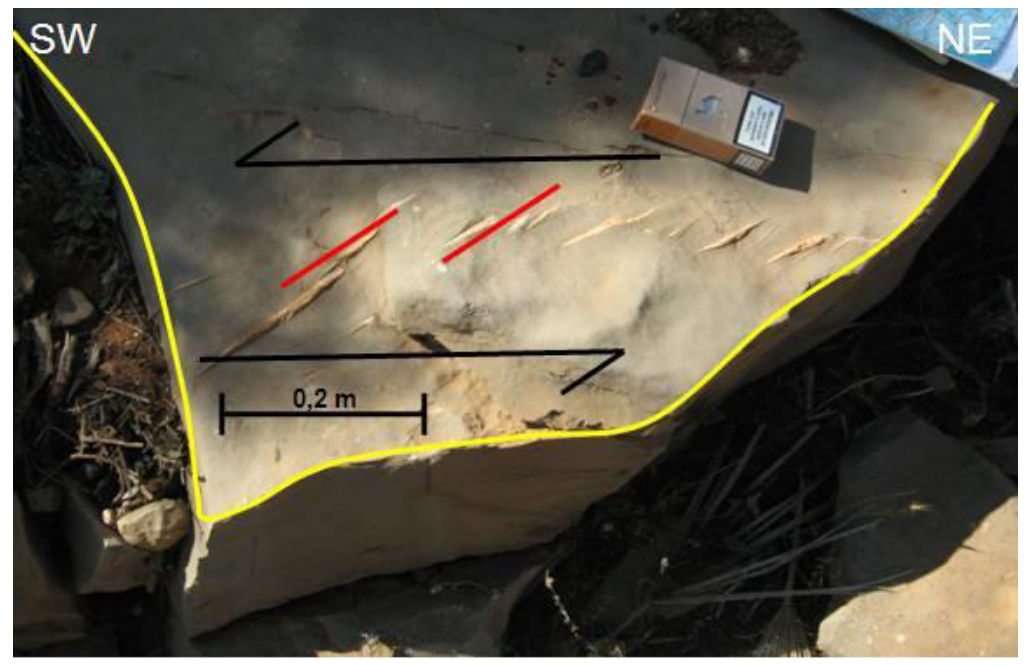

Figure 28: Outcrop $n^{e r} 156$

- Interpretation: En echelon veins where the calcite shear zone has a plane of $170 / 68$, the bedding is 165/18. This indicates a sinistral movement. There are seen more sinistral and dextral movement sets. In this area the sinistral ones are dominant. More to the northeast the dextral ones are more representative. After rotation of the bedding to horizontal the en echelon surfaces become vertical with a strike of $045^{\circ}$ which indicates a southwest to northeast compression. Further interpretation of the en enchelon veins can be found in Chapter (6).

\subsubsection{Outcrop $n^{e r} 35$}

- Location: $\mathbf{X}=439931 ; \mathbf{Y}=3445773 ; \mathbf{Z}=345$

- Formation: J7b-n1, Calcaires de Timsilline.

- Lithology: Limestone.

- Description: Inclined layers cut by faults. A high-angle reverse fault cuts a thick, stronger bank, offsetting $20 \mathrm{~cm}$ (left picture below). Five meters north of the high-angle fault there are conjugate faults (right picture below). The planes of the most representative conjugate set are 008/55 and 183/52, with striations perpendicular to the intersection of the two planes.
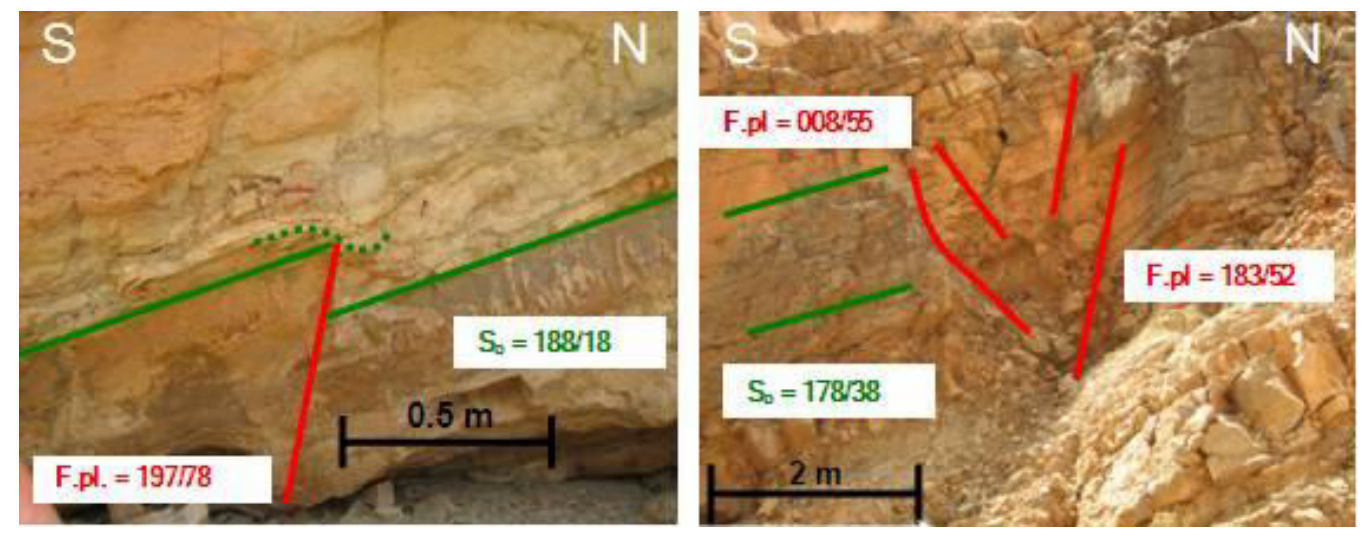

Figure 29: Outcrop $n^{\text {er }} 35$ 
- Interpretation: The reverse fault ends in the upper chaotic sedimentary layer. The marls within this layer are slumped, and show soft sediment deformation. It is presumable that movement along the reverse fault triggered an earthquake, causing the chaotic character of the sediment directly above the fault. The time of this earthquake and thus the timing of deformation is 146 to $137 \mathrm{Ma}$ (Late Jurassic to Early Cretaceous).

Table 5: Stress orientations of the conjugate set at outcrop $n^{e r} 35$

\begin{tabular}{lrr} 
& Present orientation & Before tilting \\
\hline$\sigma_{1}$ & $252 / 87$ & $184 / 51$ \\
$\sigma_{2}$ & $96 / 03$ & $276 / 02$ \\
$\sigma_{3}$ & $006 / 02$ & $008 / 39$
\end{tabular}

The conjugate fault indicates a maximum horizontal stress of 096/03 (Table 5). If the fault was created before the strata were tilted, the maximum horizontal stress would have been 276/02. The conjugate fault was most likely formed after the strata were tilted, as a result of overburden stress (the $\sigma_{1}$ is sub-vertical).

\subsection{Other outcrops not close to the profiles}

\subsubsection{Outcrop $n^{e r} 57$}

- Location: $\mathbf{X}=4464551 ; \mathbf{Y}=3447776 ; \mathbf{Z}=426$

- Formation: J7b-n1, Calcaires de Timsilline.

- Lithology: Limestone.

- Description: Approximately 30 meters long wedge that pinches out towards the south. The strata underneath the wedge are faulted. The faults have reverse offsets of a few to tens of centimetres and do not continue in the wedge. The fault surfaces show slic and slides.

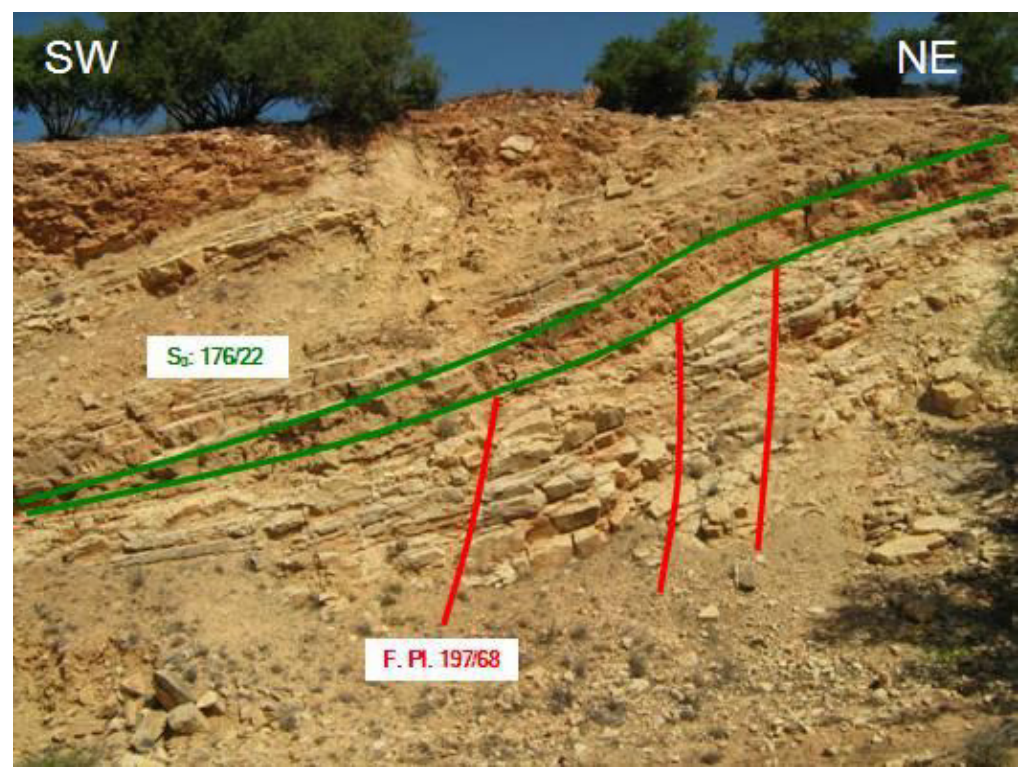

Figure 30: Outcrop $n^{e r} 57$ 
- Interpretation: The reverse faults were formed at the time when the sediments in the wedge were being deposited; 146 to $137 \mathrm{Ma}$ (Late Jurassic to Early Cretaceous). The shortening direction is SSW-NNE, with top to the northnortheast (Figure 31).

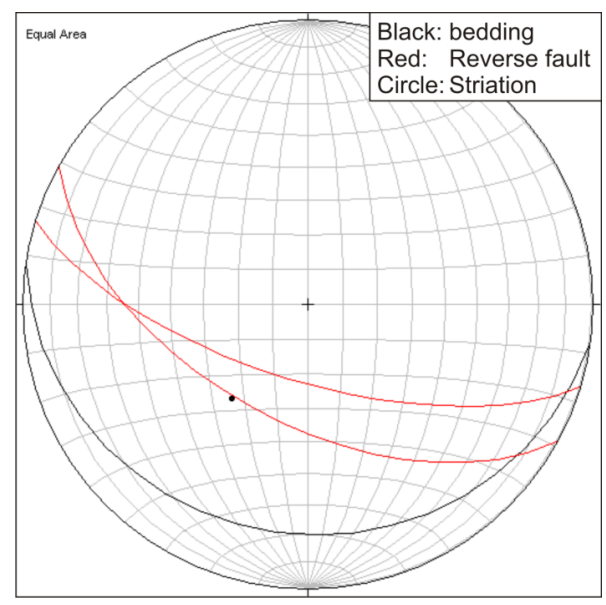

Figure 31: Stereoplt of bedding and faults. 


\section{Profiles}

A total of eight profiles have been made to construct the structure of the Jbel Amsittene. Six profiles run along the strike of the anticline and two are perpendicular to it. The profiles are extracted from a large dataset of field observations and the outcrops described in the previous chapter.

The formation boundaries are based on the geological map from the Moroccan Geological Survey (Geological map of Tamanar). The formation names are also from this map. See Figure 10 and Appendix 11.1.

\subsection{Profiles perpendicular to the fold axis}

\subsubsection{Profile $E-E^{\prime}$.}

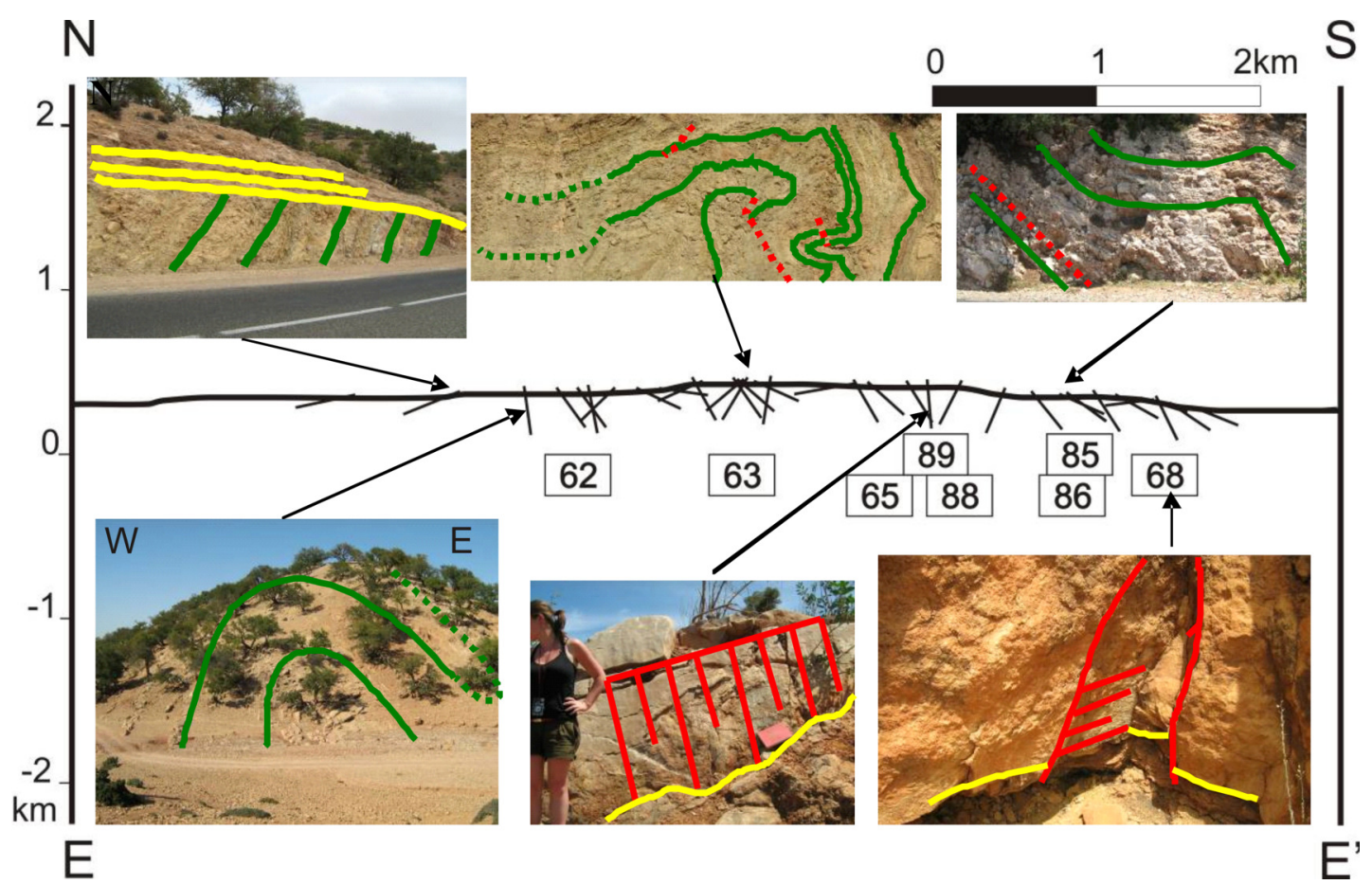

Figure 32: Measured dips of the bedding along profile $E-E^{\prime}$ with pictures of the most important outcrops.

Section $E-E^{\prime}$ (Appendix 11.4) is perpendicular to the fold axis of the Amsittene anticline and is situated along the main road from the cities Essaouira to Agadir (Figure 1, Figure 32 and Appendix 11.2).

The northern part of the section is covered by quaternary marine terraces. Towards the south, these terraces can be found until outcrop $n^{e r} 62$ (Appendix 11.2). This outcrop shows the discordant contact between the terraces and the Jurassic rocks underneath. The Jurassic rocks are tilted approximately $80^{\circ}$ towards the northwest. This tilt increases towards the south to sub-vertical and even $60^{\circ}$ overturned at outcrop $n^{\text {er }} 62$. Near the outcropping salt (Chapter 5), the rocks are highly distorted. The part of the section that is influenced by diapirism starts $400 \mathrm{~m}$ northwest of outcropping salt, until $200 \mathrm{~m}$ southwest of the diapir. Within this area, the strike of the layers is almost parallel to the salt dome (Appendix 11.2). Outside this area, the strike of the layers is global; WSW-ENE. South of the local distorted rocks, the strata show northern vergence. However, from outcrop $n^{e r} 63$ to further south the vergence is south.

Between outcrop $n^{e r} 63$ and $n^{e r} 65$ vertical axial planes dominate. Further towards the south the strata become highly inclined $\left(70^{\circ}\right)$ and near outcrop $n^{e r} 88$ they are overturned. This remains constant towards the south until outcrop $n^{e r} 86$, where strata are not overturned and dip approximately $40^{\circ}$ towards the south. Outcrop $n^{e r} 86$ shows a syn-sedimentary ramp fold with soft sediment deformation. From this outcrop towards the south, the dip of the layers decreases. In the youngest Jurassic formation we find outcrop $n^{e r} 68$. In these south dipping layers there are three conjugate sets, indicating N-S to NNE-SSW (see Chapter 6.3.1) and there are north vergent folds. In the most southern part of the section Cretaceous rocks are exposed with comparable direction and dip as the youngest Jurassic rocks, see Figure 33. 


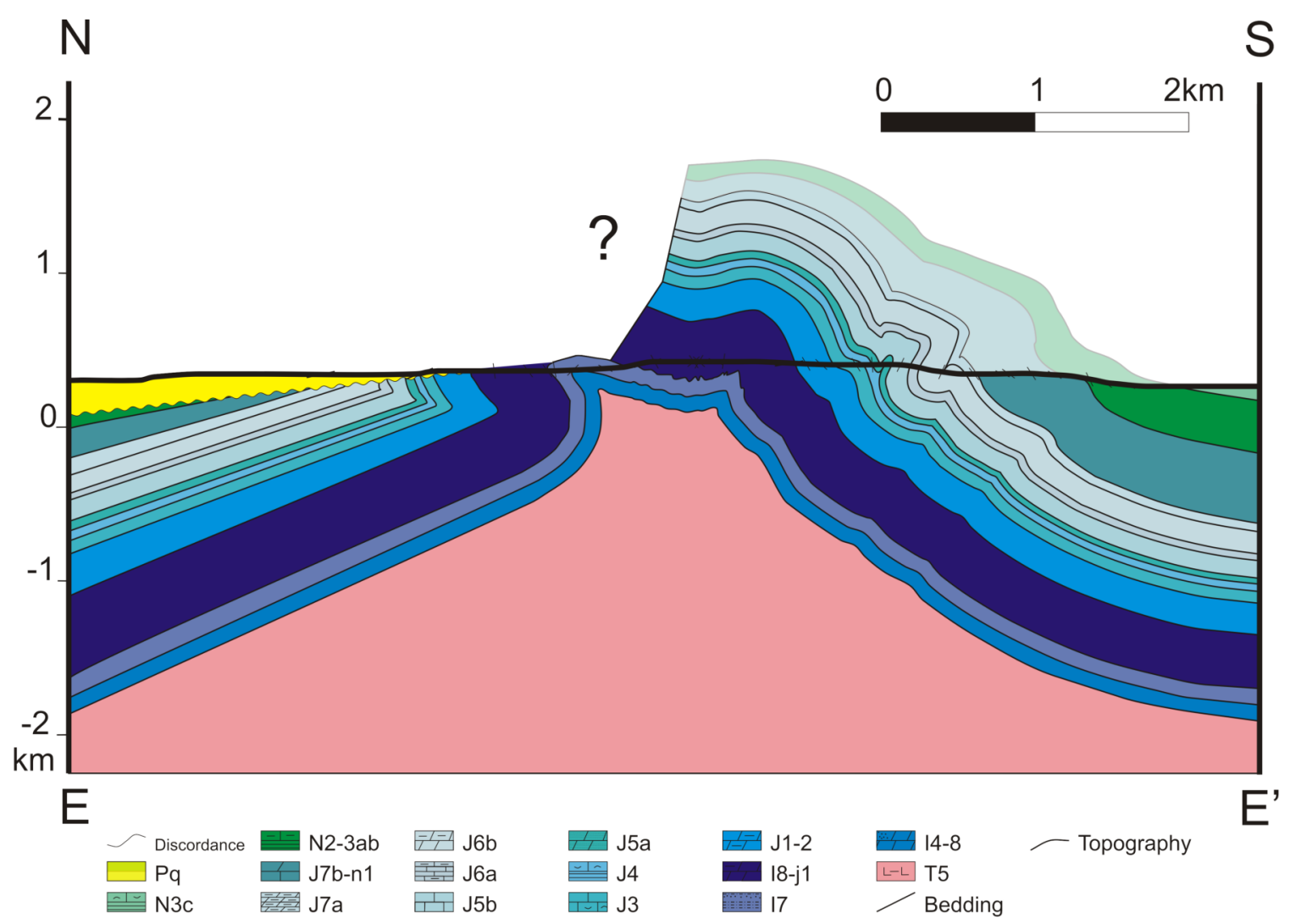

Figure 33: Structural interpretation of profile $E-E^{\prime}$.

\subsubsection{Profiles parallel to $E-E^{\prime}$.}

The sections east of profile $E-E^{\prime}$ do not differ much from it. Profile $A-A^{\prime}$ (Appendix 11.5), $4 \mathrm{~km}$ east of section $E-E^{\prime}$ shows great similarity. The two most important differences are; (1) the absence of outcropping salt in section $A-A^{\prime}$, and (2) the exposure of Late Jurassic and Cretaceous rocks in the northern part of the section. These rock dips change from sub-vertical near the transition from Jurassic to Cretaceous rocks, to $10-20^{\circ}$ in the Early Cretaceous formations. This decrease in dip in the youngest formations is also well exposed in outcrops along section $B-B^{\prime}$ (Appendix 11.6), which is a profile eastwards to $E-E^{\prime}$ and $A-A^{\prime}$. Layers in this profile are not as inclined as we have seen in the western profiles. This difference is even better exposed in profile $I-I^{\prime}$ (Appendix 11.7), where the structure of the anticline is simple, with the dip of the layers very constant in northern and southern limbs. The hinge point of the anticline is well confined and the layers hardly fold on small scale. The easternmost profile, $G-G^{\prime}$ (Appendix 11.8) is different from all the other sections. On a regional scale the layers have a maximum dip of $30^{\circ}$. Only on a local scale layers are steeper. The orientation of the layers also varies laterally, see Appendix 11.1. In this appendix it is shown that the area west of profile $E-E^{\prime}$ is completely covered by quaternary marine terraces. Along the coast there is a narrow strip of exposed Upper Jurassic rocks. Field data have been extracted from the accessible southern part of the Jurassic rocks (Appendix 11.1) in section $H-H^{\prime}$ (Appendix 11.3 and Figure 34). There is no data from the northern part due to bad accessibility. The Jurassic rocks in the southern part of the section dip around $60^{\circ}$ towards the south. The dip decreases approximately $600 \mathrm{~m}$ towards the north to sub-horizontal, or slightly dipping towards the west. 


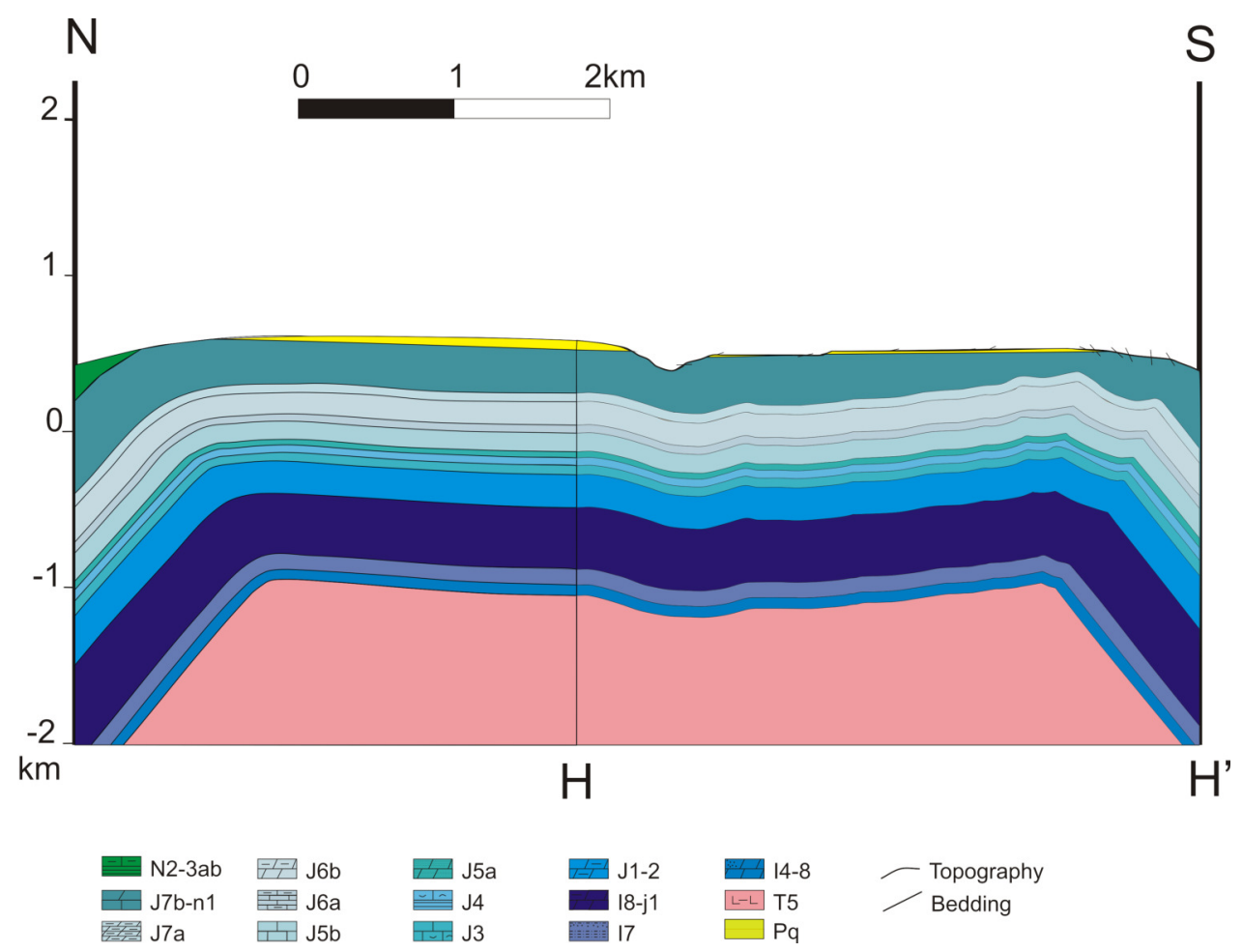

Figure 34: Extrapolation of profile $H-H^{\prime}$. The right half is profile $H-H^{\prime}$. The left half is an interpretation of the geologic map of Tamanar from the Geological Survey of Morocco.

\subsection{Profiles parallel to fold axis}

One profile has been constructed that runs parallel to the fold axis of the Amsittene anticline (Appendix 11.1 and 11.9). It is approximately $30 \mathrm{~km}$ long and runs from the coast to the easternmost part of the anticline. Field data have been obtained from the exposed Jurassic rocks. As approximately $8 \mathrm{~km}$ of the profile are covered by quaternary marine terraces there is no field data available from this area. In general it is found sub-horizontal layers. This changes near the edges of the profile. In the east part of the profile the layers dip towards the east with an angle of $10-30^{\circ}$ for some $5 \mathrm{~km}$, after which the layers become sub-horizontal again. Near the coast the strata dip towards the west.

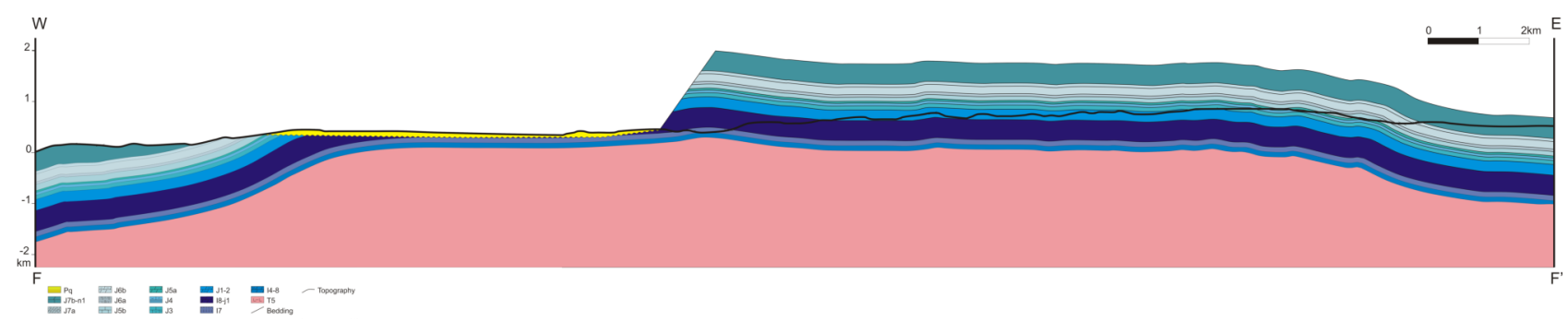

Figure 35: Structural interpretation of profile $F-F^{\prime}$, parallel to the fold axis.

\subsection{Interpretation and extrapolation of the profiles}

Profile $E-E^{\prime}$ shows that the Jbel Amsittene anticline is an asymmetrical anticline with a northern vergence. However, in depth, the anticline is more symmetric. The northern limb of the anticline is slightly overturned and near the hinge distorted by salt diapirism, which resulted in folding parallel to the salt dome. In more detailed view, the Amsittene anticline consists in two smaller-scale anticlines. Profile $A-A^{\prime}$ and $B-B^{\prime}$, east of $E-E^{\prime}$ also show these two anticlines with northern vergence (See Appendix 11.4 to 11.9 and Figure 36). Profile $H-H^{\prime}$, near the coast, only shows the southern part of the Amsittene anticline. This profile, combined 
with limited geologic data from the geologic map of Tamanar from the Geological Survey of Morocco, shows a box fold (Figure 34).

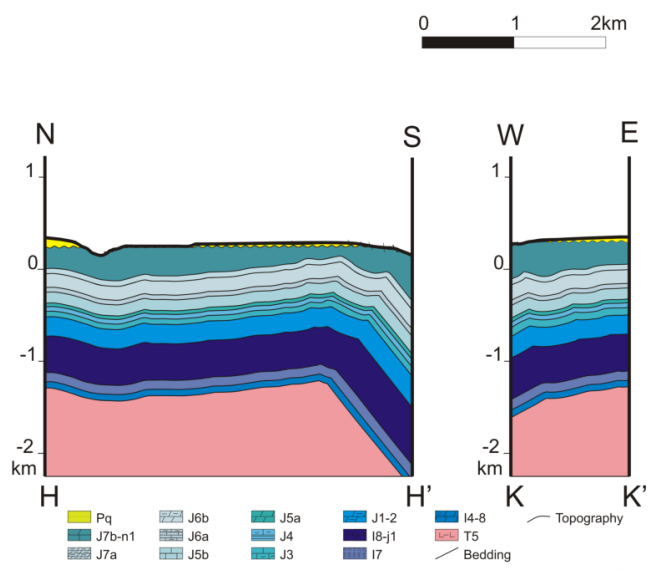

(i) Profile $H-H^{\prime}$ and $K-K^{\prime}$

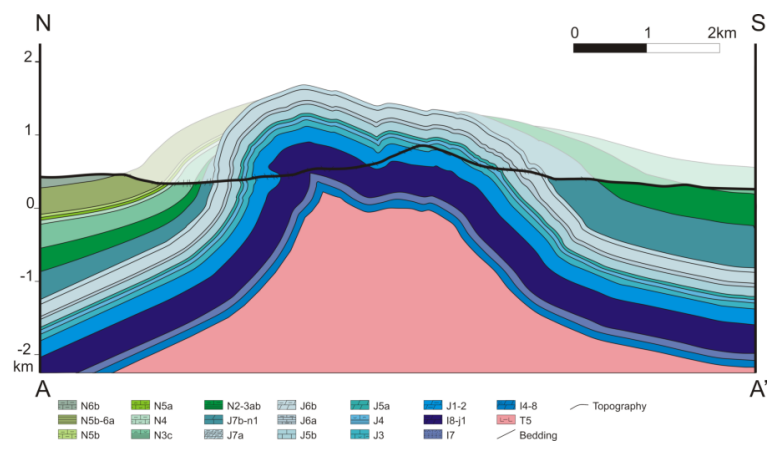

(iii) Profile $A-A^{\prime}$

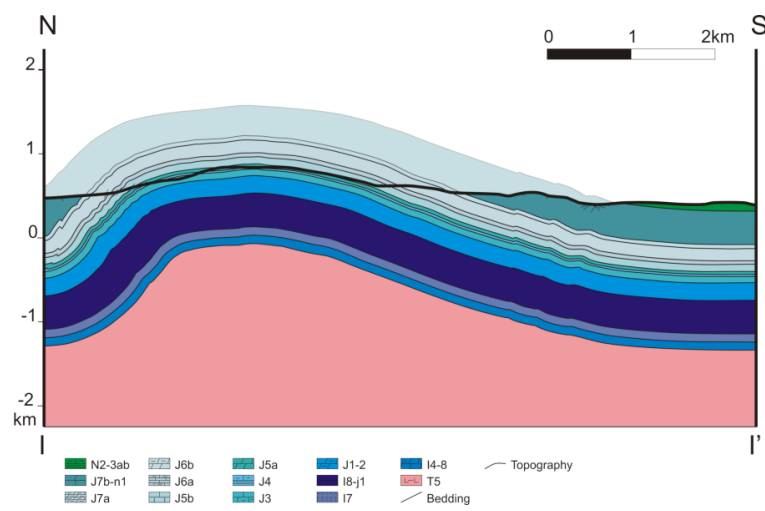

(v) Profile $I-I^{\prime}$

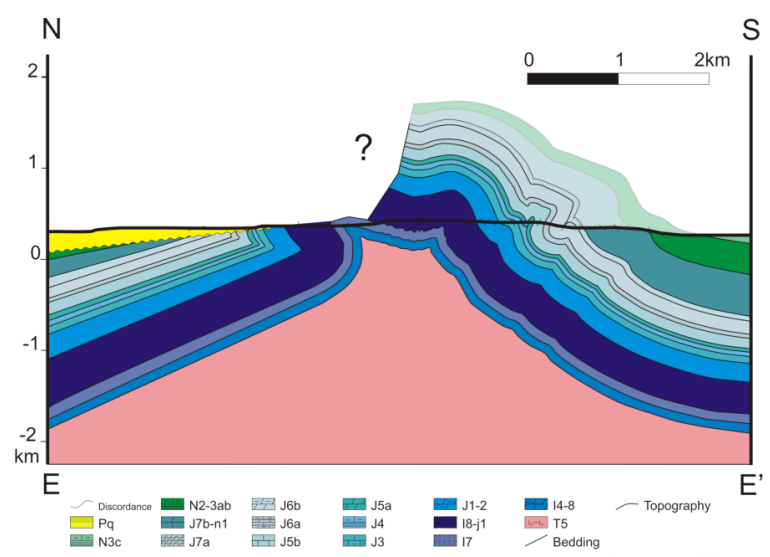

(ii) Profile $E-E^{\prime}$

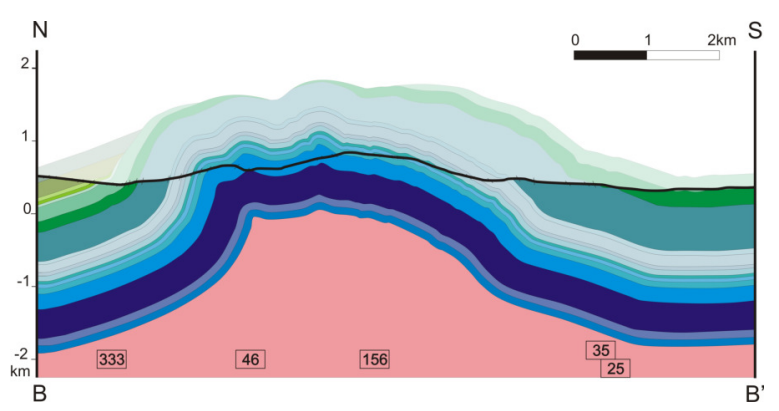

(iv) Profile $B-B^{\prime}$

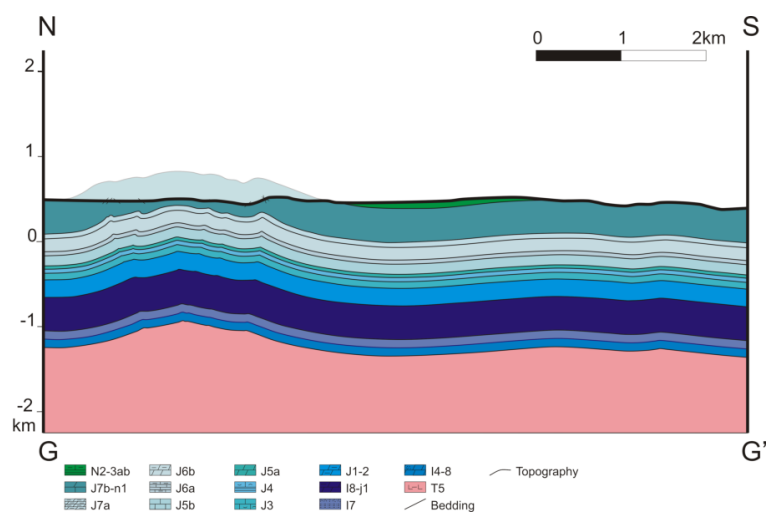

(vi) Profile $G-G^{\prime}$

Figure 36: Geological profiles $H-H^{\prime}, E-E^{\prime}, A-A^{\prime}, B-B^{\prime}, I-I^{\prime}$ and $G-G^{\prime}$, from west to east, see Appendix 11.1 for the locations. The outcrops described in Chapter 3 are also indicated. See for the legend the Appendix.

In profile $E-E^{\prime}$ and $A-A^{\prime}$, the Amsittene anticline has steep limbs (Figure 36). The steepness of the limbs decreases towards the east. Also the small scale folding becomes less intense. The easternmost profile is a very open and symmetrical anticline, with no clear vergence (Figure 36). The profiles show that most of the deformation during the Late Jurassic took place in the middle part of the Jbel Amsittene (Profiles $E-E^{\prime}$, $A-A^{\prime}$ and $\left.B-B^{\prime}\right)$. Deformation was most intense in the midle part and diminishes to the west and east by the end of the Jurassic - Early Cretaceous, where deformation was less intense. 
The amount of shortening is measured along the upper boundary of the J7b-n1 formation and decreases from more than $2 \mathrm{~km}$ in profile $A-A^{\prime}$ to only $200 \mathrm{~m}$ in the east (Table 7 ). The greatest amount of shortening is in the middle part of the anticline, in profile $A-A^{\prime}$.

Table 6: Decrease in amount of shortening to the east.

\begin{tabular}{lcc} 
Profile & Deformed length $(K m)$ & Shortening (Deformed-horizontal length) $(K m)$ \\
\hline Profile $E-E^{\prime}$ & 7,6 & 1,6 \\
Profile $A-A^{\prime}$ & 9,5 & 2,1 \\
Profile $B-B^{\prime}$ & 10,3 & 1,5 \\
Profile $I-I^{\prime}$ & 9,1 & 0,6 \\
Profile $G-G^{\prime}$ & 4,3 & 0,2
\end{tabular}

The thickness of the J7b-n1 and N2-3ab formation (the Late Jurassic and Early Cretaceous formations) obtained from the profiles varies laterally (Table 7). Profile $A-A^{\prime}$ and $E-E^{\prime}$ show differences of up to $350 \mathrm{~m}$ between the formations outcropping in the north and in the south. Towards the east, the variation in thickness decreases, as can be seen in profile $I-I^{\prime}$, profile $G-G^{\prime}$, and also towards the west, as observed in profile $H-H^{\prime}$ and $K-K^{\prime}$ (Appendix 11.7, 11.8 and 11.3 respectively). The Timsilline formation here has a constant thickness of approximately $400 \mathrm{~m}$.

Table 7: Differences in thicknesses of J7b-n1 and N2-3ab formations, on profile $A-A^{\prime}$ and $B-B^{\prime}$.

\begin{tabular}{lrr} 
& Berriasian (J7b-n1) & Vallanginian-Middle Hauterivian (N2-3ab) \\
\cline { 2 - 3 } & $\mathbf{N}-\mathbf{S}$ & $\mathbf{N}-\mathbf{S}$ \\
\hline Profile $A-A^{\prime}$ & $150 m-500 m$ & $100 m-450 m$ \\
Profile $E-E^{\prime}$ & $400 m-600 m$ & $150 m-250 m$ \\
\hline Other profiles & No control & in thicknesses: Marine terraces or non-outcropping
\end{tabular}

There are several ways to explain these significant thickness differences. Figure 38 shows three different versions of profile $A-A^{\prime}$. In Scenario $I$ the thickness of the Late Jurassic and Early Cretaceous formation increases gradually from north to south. Scenario $I I$ and $I I I$ are very different. In these two scenarios the Late Jurassic - Early Cretaceous formations pinch out on the Amsittene anticline. The difference between the two scenarios is that the wedges of Scenario II are much wider than for Scenario III. There is no data on possible thickness differences of younger formations. Our field data favor Scenario II and III over I. There are several syntectonic structures that indicate shortening during deposition of Timisilline (J7b-n1) formation. A key observation is a $30 \mathrm{~m}$ scale wedge in Timsilline formation (outcrop $n^{o} 57$ ) in the south-eastern part of the field area. In the exposed Aptian and Albian rocks, in the northern part of the study area, there are no syntectonic structures. Therefore, we are fairly sure that only the Timisilline (J7b-n1) and the Lower cretaceous (N2-3ab, N3c and maybe N4c) might be wedge-shaped.

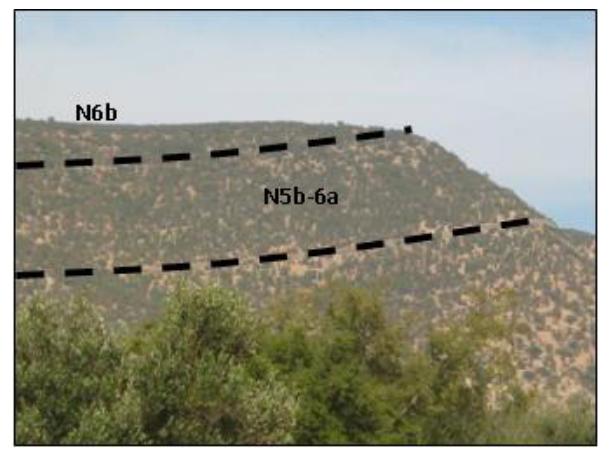

Figure 37: Panorama view of the Neknafa syncline, north of the Jbel Amsittene, anticline which does not show a wedge shape in the Cretaceous sediments. 

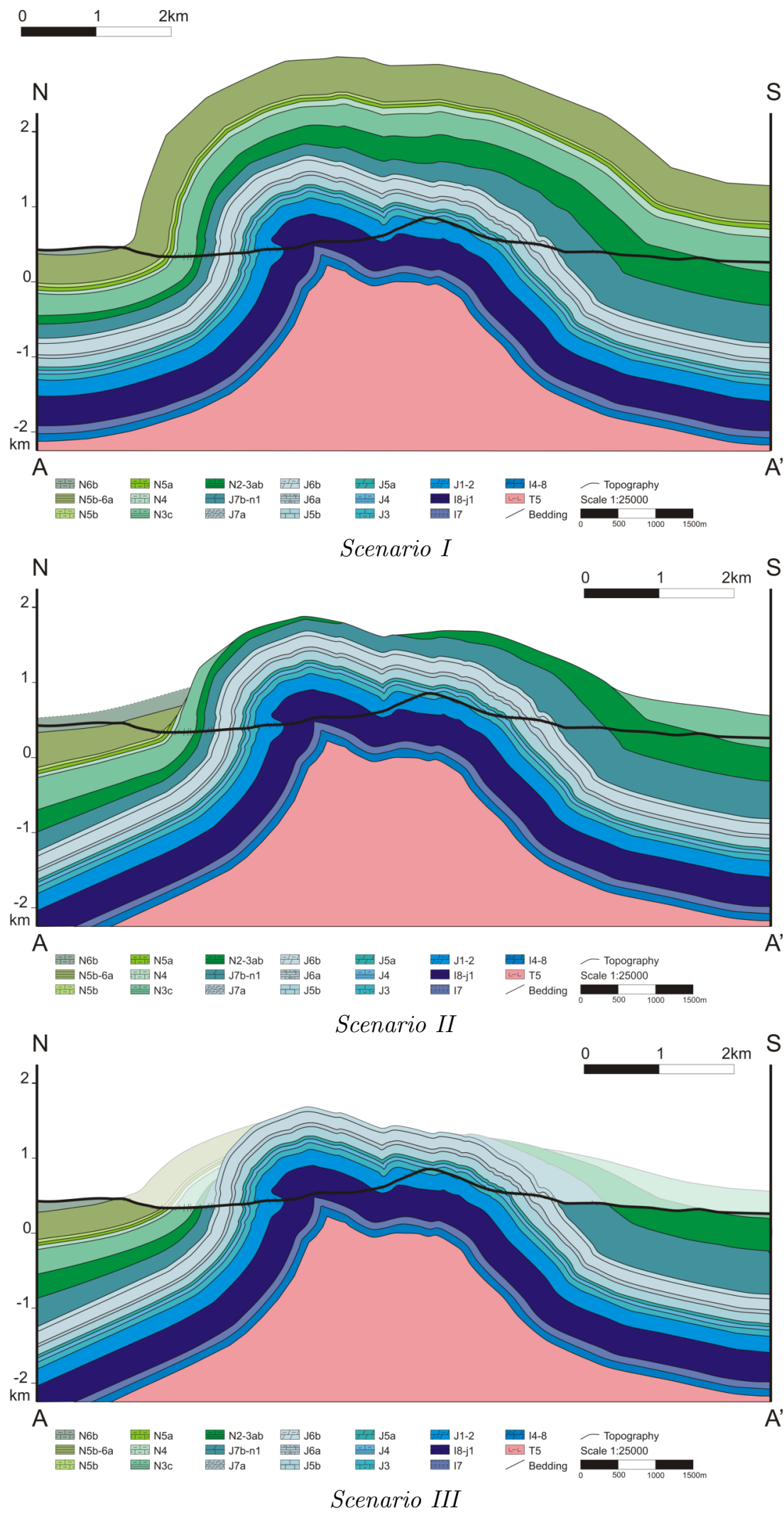

Figure 38: Extrapolation of profile $A-A^{\prime}$ as evolved in three different scenarios. 


\subsection{Paleo-spatial reconstruction}

We have used field data to reconstruct geological profiles of the area through time. All profiles are from the same location, section $A-A^{\prime}$ (Figure 39), and run in NNW-SSE direction. The differences in thicknesses of the Late Jurassic and Early Cretaceous formations have been a key factor in the construction of these profiles. To understand the implications of the three different scenarios on the evolution of the Amsittene anticline, paleo-spatial reconstruction profiles of all these scenarios have been made (Figure 39). In order to construct these profiles, two important assumptions have been taken into account; (1) deposition of sediments was always horizontal and (2) sedimentation during Late Jurassic and Early Cretaceous was in a shallow marine water environment (Table 1). Little variations in deposition depth might however influence the profiles.

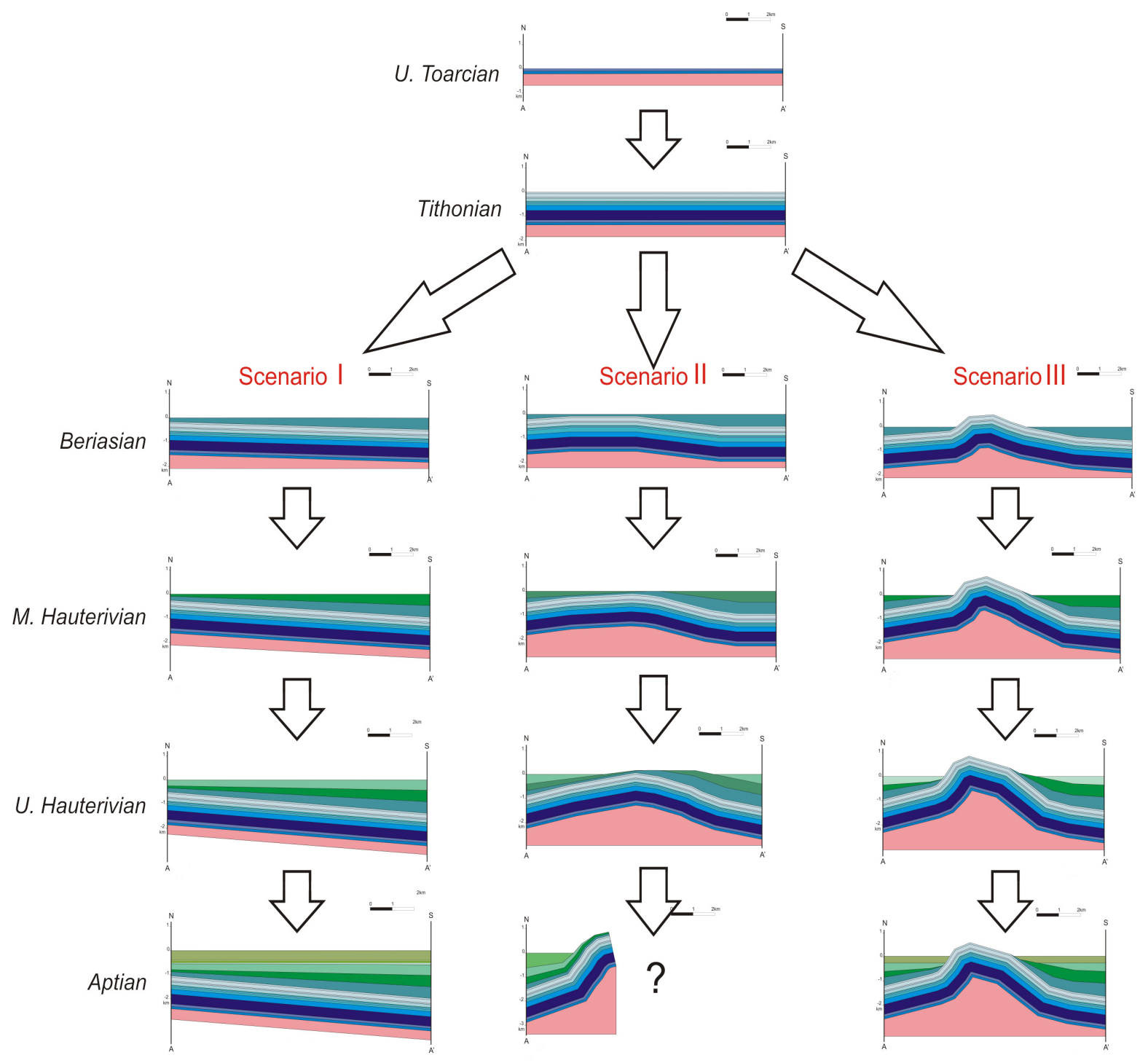

Figure 39: Paleo-spatial reconstruction of profile $A-A^{\prime}$ from the Early Jurassic until Early Cretaceous.

In all three scenarios there is horizontal deposition during the Early and Middle Jurassic, and evolved differently since the Berriasian.

For scenario $I$ (Figure 39) there is a period of (relative) increased subsidence in the south in comparison with the north. This period of differential subsidence starts in the Berriasian and lasts at least until the N2-3ab formation. It is unsure when it ends. The Amsittene anticline is formed after the deposition of these formations, probably during the Atlasic deformation. 
In scenario II (Figure 39) there is a small amount of shortening during the Late Jurassic and Early Cretaceous. Shortening increases drastically during the Aptian/Albian. However, due to lack of data from both southern and middle part of the area there are too little constraints to reconstruct the southern part of the profile for this period. The geometry of the anticline changes in time. During the first stages of deformation the anticline has a southern vergence, which changes to northern vergence as shortening increases.

In scenario III (Figure 39), the major part of the shortening occurs during deposition of the J7b-n1 and N2-3ab formation. The shortening stops in the Barremian, and the anticline already has a similar to nowadays shape. Only little reactivation occurred during a later stage, probably during the Atlasic deformation. The anticline has a clear northern vergence during the first stages of deformation, which does not change through time; however, the northern vergence is not as strong as it was in the first stages.

Our data fit scenario III best as all syn-sedimentary deformation is found in the Timsilline (J7b-n1) formation. This means that most deformation occurred in the Late Jurassic to Early Cretaceous (Berriasian to Hauterivian) and there was only little reactivation during a later period. The clear asymmetry of the anticline indicates that shortening was accommodated by a fault propagation fold.

\subsection{Seismic interpretation}

Close to profile $E-E^{\prime}$ there is a N-S trending seismic profile. It runs north of the Amsittene anticline, until the northern limb of the anticline. Figure 40 shows the southern part of the profile. Combining well data and previous studies (e.g. Hafid, 2000), we can identify several domains within this profile; Palaeozoic basement (underneath orange line, Figure 40), Triassic strata (in between orange and lower blue line); Jurassic strata (in between the blue lines) and Cretaceous strata (above the upper blue line).

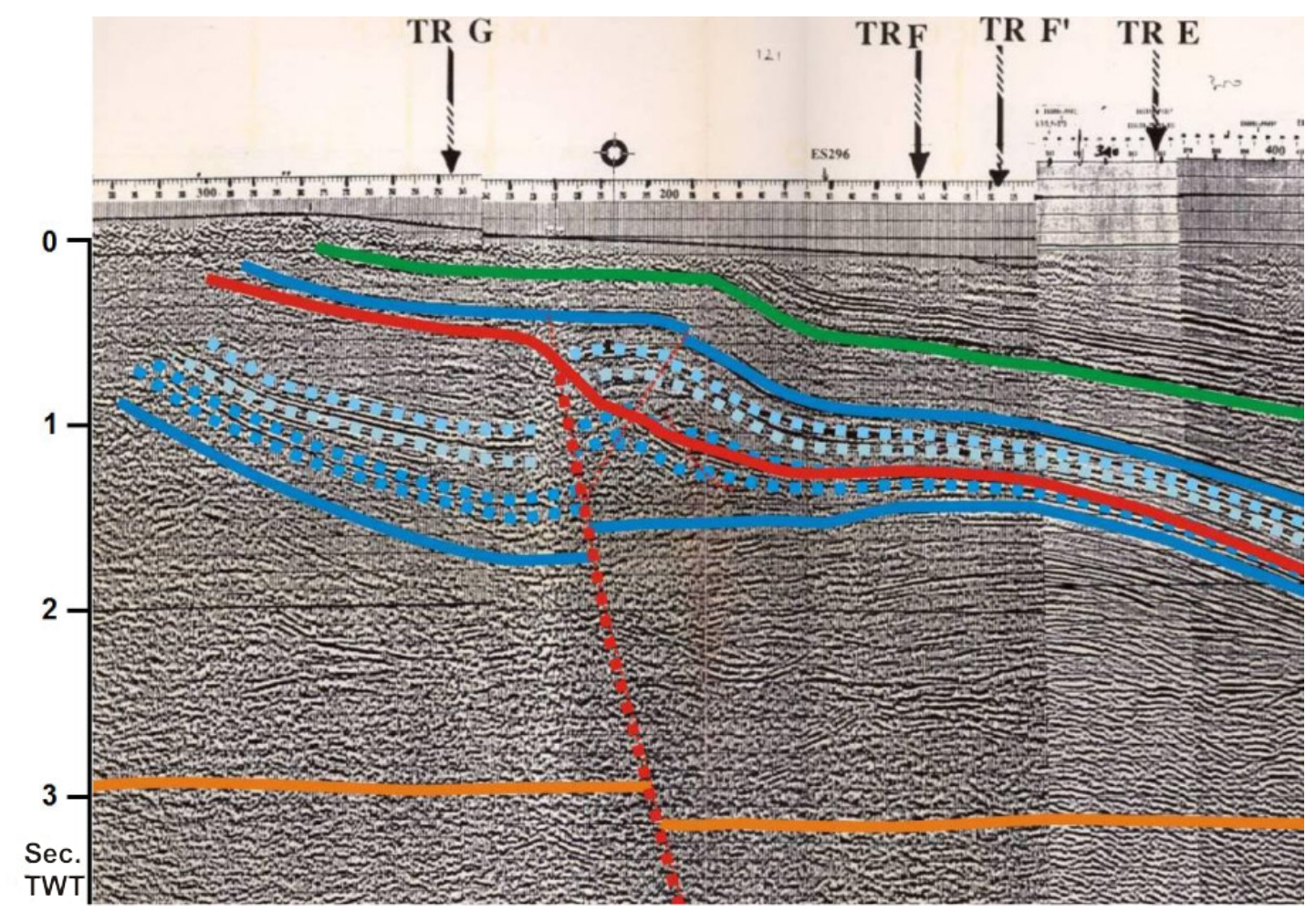

Figure 40: S-N seismic profile north of the Jbel Amsittene, see Figure 2 for exact location. Underneath orange $=$ Paleozoic basement; between orange and blue = Triassic; in between blue = Jurassic; above blue = Cretaceous. Green line $=$ marker layer within Cretaceous; red lines = faults. 
The Palaeozoic basement, Triassic strata and the lower part of the Jurassic strata are cut by a high-angle fault (Figure 40). The fault is located $15 \mathrm{~km}$ north of the Jbel Amsittene. The offset of the fault near the Palaeozoic basement is normal, but is reverse in the Jurassic layers. This reverse offset decreases in depth. In the hanging wall of the fault there are syn-tectonic wedges within the Lower Jurassic rocks, clear indicators of normal movement of the fault during the Early Jurassic. Earlier there must also have been extension, as the normal offset of the Palaeozoic basement was greater than the offset in the Jurassic rocks. During the Late Jurassic inversion of the fault was reverse led to a reduced normal offset of the Palaeozoic basement and a reverse offset within the Jurassic rocks. The wedge in the footwall of the high-angle fault, in between the upper dotted blue layer and the upper solid blue layer might have formed as a result of this movement. However, the formation of the Amsittene anticline might also be the cause of the formation of the wedge.

The thrust in the Cretaceous sediments with top to the south movement was active during the Atlasic deformation phase. It is possible that there was also movement along this fault in the Late Jurassic-Early Cretaceous.

\subsection{Summary}

The constructed profiles show that the Jbel Amsittene is a double north vergent asymmetrical anticline that ends approximately $30 \mathrm{~km}$ landward and continues offshore, regarding the continues steep south flank and also according the paper of Hafid, 2000. The geometry of the anticline may suggest that it is a fault propagation fold, with maximum amount of shortening of $1900 \mathrm{~m}$ and northern vergence. The influence of salt diapirism and migration is local. Profiles $A-A^{\prime}$ and $B-B^{\prime}$ show significant changes in thickness for formations J7b-n1 and N2-3ab of respectively 800 and $400 \mathrm{~m}$. 


\section{$5 \quad$ Salt tectonics}

The Atlantic margin of NW Morocco is one of the oldest undeformed passive margins on earth (around 180-200 $\mathrm{Ma}$ ) and it is conjugate to the Nova Scotia margin of North America. Salt is present in the sections of most onshore and offshore basins and has generally played an important role in their post Triassic tectono-sedimentary evolution. Along the majority of the Moroccan margin, the seaward edge of the salt diaper province corresponds spatially to the ocean-continent boundary as identified from seismic velocities and magnetic anomalies (F. Klingelhoefer, 2008).

The Jbel Amsittene anticline has a salt core of Triassic age. One of the main points of this study it to determine the possible forces of creation of the anticline, being active diapirism and halokinesis the most important hypothesis until nowadays. Seismic studies from Hafid (2000) concluded that the Jbel Amsittene (and other related structures in NW Morocco) might be created by active salt processes.

Without taking into account previews studies, we have two different possibilities of how the anticline was formed (a) salt layer allows lubrication and decoupling of the overburden from its basement and fills the anticline core and (b) thicker salt forms diapers before contraction, forcing the overlaying to fold. To make this distinction, we had specially studied and focus on the outcropping area of the salt. Five kilometres south from the village Smimou the salt is exposed in an approximately $1 \mathrm{Km}$ diameter circular depression (see Figure 1, Figure 41 and 11.1).

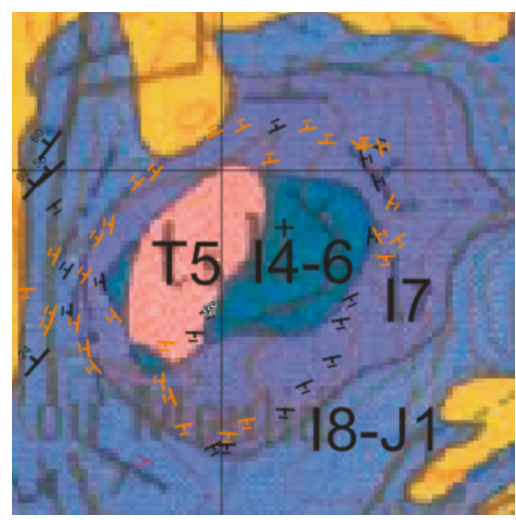

Figure 41: Salt mine with the adjacent formations and strikes of the bedding surrounding the salt T5 outcrop.

We have checked the following aspects to recognize what situation we have in the Jbel Amsittene area:

When salt is driven by diapir pressure, it acts as an active diaper and intrudes its overburden. Therefore, salt diapirs often crosscut younger strata, while salt-cored anticlines have concordant contacts.

Active diapers are surrounded by radial faults if regional extension has ceased or by sub-parallel normal faults if extension accompanies piercement (Stewarts, 2006; Hudec and Jeckson, 2007)). Erosional thinning and weakening of the roof stimulate further active rise, while adjoining redeposition increases the pressure for salt breakout. The displaced flaps oversteepen and slump onto the flanking overburden as chaotically resedimented, recumbently folded, imbricately thrusted strata.

In our study area, Jurassic layers around the salt outcrop dip away from it, with dips varying from subvertical to 25 (normally they gain dip while moving towards the salt). Between the salt T5 formation and the I4-6 and I7 formations there is an intrusive contact (Figure 10 and Table 1). This fact and the dip of the Jurassic layers around the salt indicate salt diapirism. The active halokinesic-related structures are local, as a few hundred meters away in any direction from the outcropping salt, the layers have a regional position with respect to the Amsittene anticline. They are characterized by $\mathrm{E}-\mathrm{W}$ to $\mathrm{SW}-\mathrm{NE}$ strike, regional for the area. It is very likely though that the salt forms a ridge underneath the Jbel Amsittene anticline. According to the profiles the salt itself has acted as a detachment layer. The absence of extensional structures in the Jbel Amsittene anticline area is striking, as they might be expected to form during salt diapirism. All these facts clearly indicate that the Jbel Amssitene anticline was not formed by salt tectonics, but by compressional forces.

Structures in the Moroccan margin region are still widely attributed merely to buoyant up-welling of salts by gravity-driven halokinesis. Extrapolating the observations obtained in this study to the similar genetic-related folds in the Moroccan margin we conclude that rather, they must have formed by regional contraction during inversion, and salt merely collected in the lower-pressure anticline cores. 


\section{Structural evolution}

Based on structural features, such as folds, faults, stylolites and conjugate sets, strain and stress directions have been derived. Established on these local and regional directions we have interpreted the structural evolution of the Amsittene anticline.

\subsection{Strain}

Strain is the deformation of rocks caused by stresses. This results in folds and faults. These deformations tell us something about the orientation of extensional and contractional events during their formation.

\subsubsection{Folds}

The obvious deformation in the Jbel Amsittene anticline is due to a north-south to northwest-southeast shortening. This is also in line with the major part of al the smaller folds measured in the area. In contrast some folds do have a totally different orientation, see Figure 42. The nine fold axes with a north to south orientation are all from the J7b-n1 and N2-3ab formations, i.e. the upper most Jurassic and the lower most Cretaceous. The J7b-n1 is also the formation with the widest distribution of fold axes. These facts might suggest a second phase of deformation after the end of the Upper Jurassic with an east to west shortening direction.

Figure 42: Equal area projection of all the fold-axes on lower hemisphere.

Green rhombus are the J7b-n1 formations or younger. Density plot has contours of 1,5

with the maximum of 10 at $081 / 06$. The rose diagram is based on the dip directions in classes of $10^{\circ}$.

Fold-axes within the rectangle box indicate the possible second phase of east-west shortening.

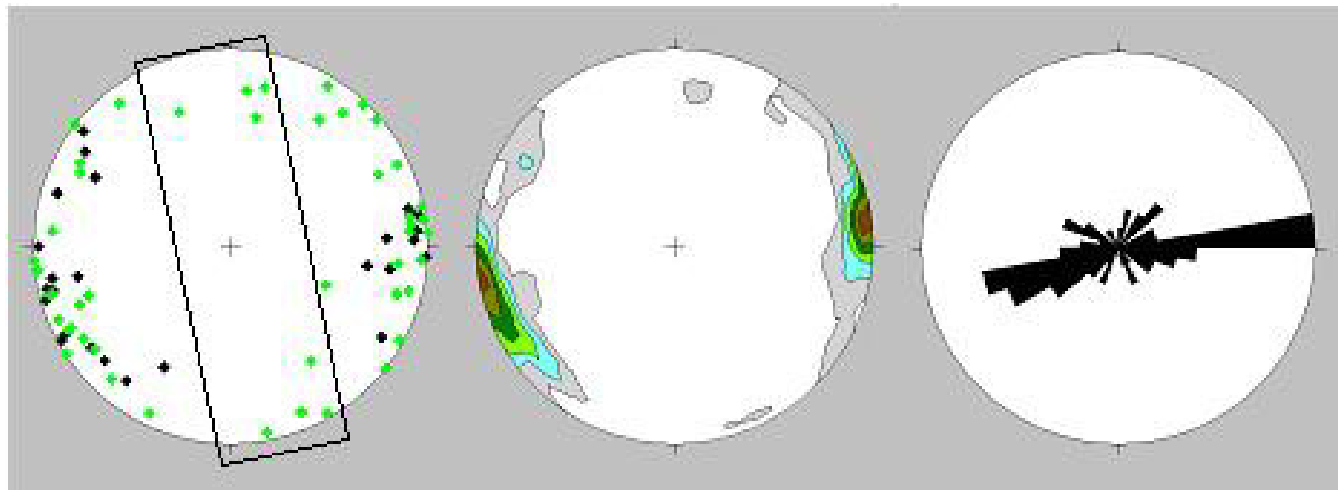

Interpretation: Fault-bend fold, with top to the south movement. The fold in the hanging wall has a fold axis of 085/06 and axial plane of 022/14.

\subsubsection{Faults}

Although there are not many faults in the Jbel Amsittene, we can do some distinctive observations. For an overview of all the faults per outcrop see Table 8. For the syn-sedimentary faults the bedding is rotated back to horizontal.

\begin{tabular}{lr}
$\begin{array}{l}\text { Post-sedimentary reverse faulting } \\
\text { Layer parallel - Accomodation faults }\end{array}$ & $\begin{array}{r}\text { Syn-sedimentary faulting } \\
\text { Reverse }\end{array}$ \\
\hline $196 / 32(76 ; \mathrm{J} 1-2)-335 / 84(61 ; \mathrm{I} 8-\mathrm{J} 1)$ & $154 / 63(35 ; \mathrm{J} 7 \mathrm{~b}-\mathrm{n} 1)$ \\
$340 / 64(88 ; \mathrm{J} 3)-334 / 72(62 ; \mathrm{I} 8-\mathrm{J} 1)$ & $209 / 43(57 ; \mathrm{J} 7 \mathrm{~b}-\mathrm{n} 1)$ \\
$170 / 85(88 ; \mathrm{J} 3)-169 / 45(64 ; \mathrm{I} 8-\mathrm{J} 1)$ &
\end{tabular}

Table 8: Fault planes orientation per outcrop and formation for the post-sedimentary reverse faults and the syn-sedimentary faults. 
As Table 8 shows, the post-sedimentary faults are only in the older formations while syn-sedimentary ones are in the younger formations, which support that deformation was developing during this period (Late Jurassic and Early Cretaceous). Besides, it shows that the post-sedimentary and syn-sedimentary faults are all reverse faults.

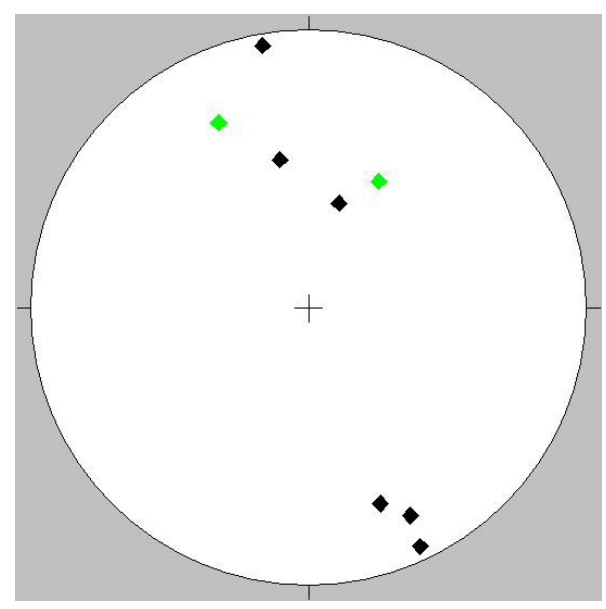

Figure 43: Stereoplot with projections of the poles of all the fault planes. Green rombhus is in the J7b-n1 formation.

All the poles of the fault planes in Figure 43 are orientated approximately in the same direction, which is in line with the deformation direction of the folds. They indicate a north-northwest to south-southeast shortening direction for most of the reverse faults. The syn-sedimentary fault of Outcrop $n^{\text {er }} 5$, shows a NE-SW shortening (Appendix II).

\subsection{Stress}

States of stresses are obtained from conjugate sets, en echelon and neptunian dykes. These features can give a clue to stress devolvement in the Jbel Amsittene area.

\subsubsection{Conjugate sets}

As conjugate sets form due to differential stresses one can derive the orientation of the $\sigma_{1}, \sigma_{2}$, and $\sigma_{3}$ throughout their formation. Most of the conjugate sets belong to the J7b-n1 formation. The others are located in the younger formations, see Table 9.

Table 9: Stress orientations of the conjugate sets in the present and their orientation when bedding was horizontal. It also shows the quality of the conjugate set and the formation of occurrence.

\begin{tabular}{|c|c|c|c|c|c|}
\hline Outcrop & Bedding & $\frac{\text { Present orientation }}{\sigma_{1}-\sigma_{2}}$ & $\begin{array}{c}\text { Orientation before tilting } \\
\sigma_{1}{ }^{\prime}-\sigma_{2}{ }^{\prime}-\sigma_{3}{ }^{\prime}\end{array}$ & Quality & Fm. \\
\hline$N^{e r} 25$ & $078 / 47$ & $264 / 53-073 / 37-167 / 05$ & $058 / 79-254 / 10-164 / 03$ & Poor & $\mathrm{N} 2 / 3 \mathrm{ab}$ \\
\hline$N^{e r} 35$ & $188 / 18$ & $252 / 86-096 / 03-006 / 02$ & $198 / 70-097 / 04-005 / 20$ & Good & J7b-n1 \\
\hline \multirow{3}{*}{$N^{e r} 68$} & $144 / 19$ & $010 / 09-256 / 68-103 / 20$ & $014 / 22-208 / 67-106 / 02$ & Very Good & J7b-n1 \\
\hline & $146 / 28$ & $203 / 28-344 / 56-103 / 18$ & $195 / 11-031 / 79-286 / 03$ & Good & J7b-n1 \\
\hline & $144 / 19$ & $183 / 01-282 / 81-093 / 09$ & $005 / 13-171 / 76-274 / 03$ & Good & J7b-n1 \\
\hline$N^{e r} 333$ & $318 / 24$ & $067 / 38-206 / 45-319 / 22$ & $047 / 41-232 / 29-139 / 02$ & Poor & N3c \\
\hline \multirow{2}{*}{$N^{e r} 346$} & $181 / 24$ & $340 / 61-073 / 02-164 / 29$ & $075 / 09-166 / 05-106 / 02$ & Moderate & J7b-n1 \\
\hline & $200 / 15$ & $293 / 76-059 / 07-150 / 10$ & $061 / 19-151 / 00-106 / 02$ & Moderate & J7b-n1 \\
\hline
\end{tabular}


A stereo-plot of all the present stress orientations does not give a clear sight on a overall stress orientation, see Figure 44(i). Even if the poor or moderate conjugate sets are left out of the figure overall stress orientation is still not clear.

If the conjugate sets are all turned back to their original position and the bedding is rotated back to horizontal, the stereo-plot shows a more distinctive view on the principle stresses, see Figure 44(ii). First, all the $\sigma_{1}$ and $\sigma_{2}$ stresses are orientated in the north-east and south-west quadrant and have a dominant position in the centre part. This configuration can be due to permutation. Secondly, all the $\sigma_{3}$ stresses are in the north-west and southeast quadrant.

But if the conjugate sets are discriminated according to their position it shows two different characteristic features. Outcrop $n^{e r} 25, n^{e r} 35, n^{e r} 333$ and $n^{e r} 346$ are characteristic of a normal fault system and the conjugate sets of outcrop $n^{e r} 68$ are typical of a strike-slip system. The normal fault conjugate sets, apart from outcrop $n^{e r} 62$, show a vertical $\sigma_{1}$ (mean vector is 231/82) and a north-northwest to a south-southeast $\sigma_{3}$ (mean vector is 346/03), see Figure 44(iii). Another remarkable observation is the parallelism of the $\sigma_{2}$ (mean vector is $077 / 04$ ) with the fold-axis of the Jbel Amsittene anticline. In the strike-slip conjugate sets (Figure 44(iv)), outcrop $n^{\text {er }} 68$, the $\sigma_{1}$ is north-northeast to south-southwest (mean vector is $017 / 05$ ) and $\sigma_{2}$ is vertical (mean vector is $186 / 82$ ). The $\sigma_{3}$ is west-northwest to north-northeast (mean vector is 282/01).

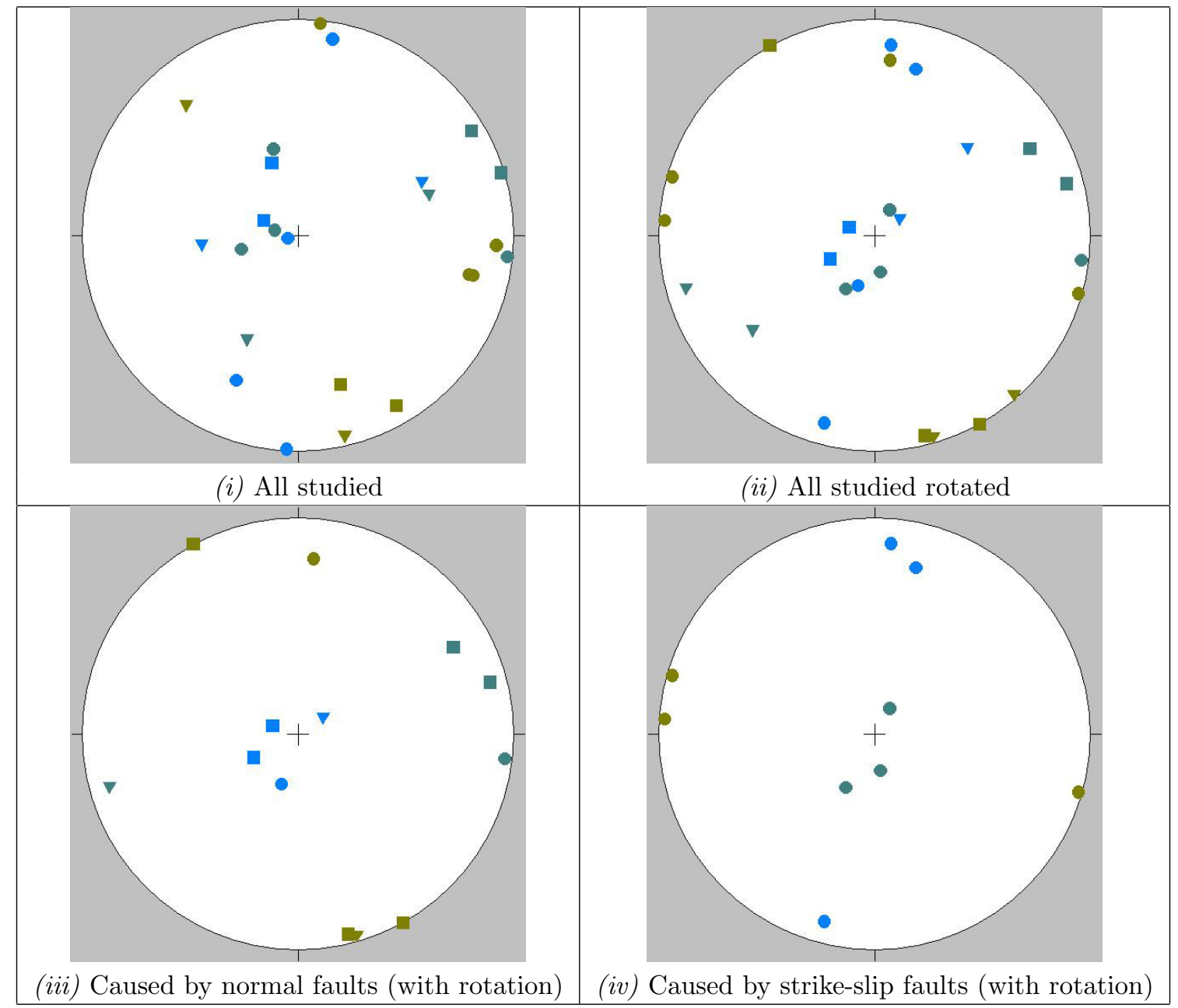

Figure 44: Principal stresses of the conjugate sets, represented as: (i) all studied, (ii) all studied rotated, (iii) caused by normal faults (with rotation) and (iv) caused by strike-slip faults (with rotation).

In these figures $\sigma_{1}$ is representaed in blue, $\sigma_{2}$ in dark blue and green colour is used for $\sigma_{3}$ 


\subsubsection{Stylolites}

Most stylolites observed in the field have a stylolite surface parallel on, and perpendicular teeth to, the bedding. This indicates a vertical $\sigma_{1}$ that is formed probably due to ordinary overburden weight. However, this is not the case for outcrop $n^{e r} 46$, which shows several different stylolite configurations.

After rotation of the bedding to horizontal, the $\sigma_{1}$ are all orientated in a roughly north-northwest to southsoutheast direction, see Figure 45.

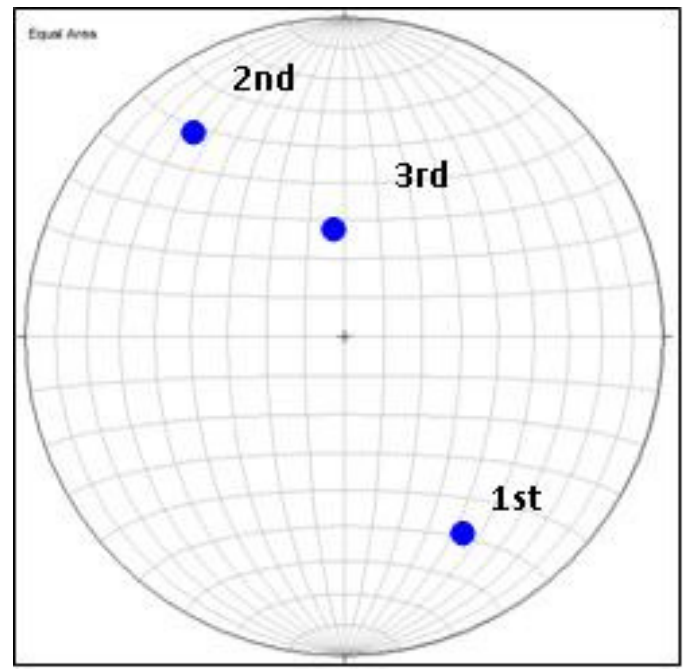

Figure 45: Orientations of the stylolite teeth if the bedding is horizontal.

Although the measurements are not that precise it shows an approximate N150E to sub-vertical compression (overburden), which can be explained by the model below.

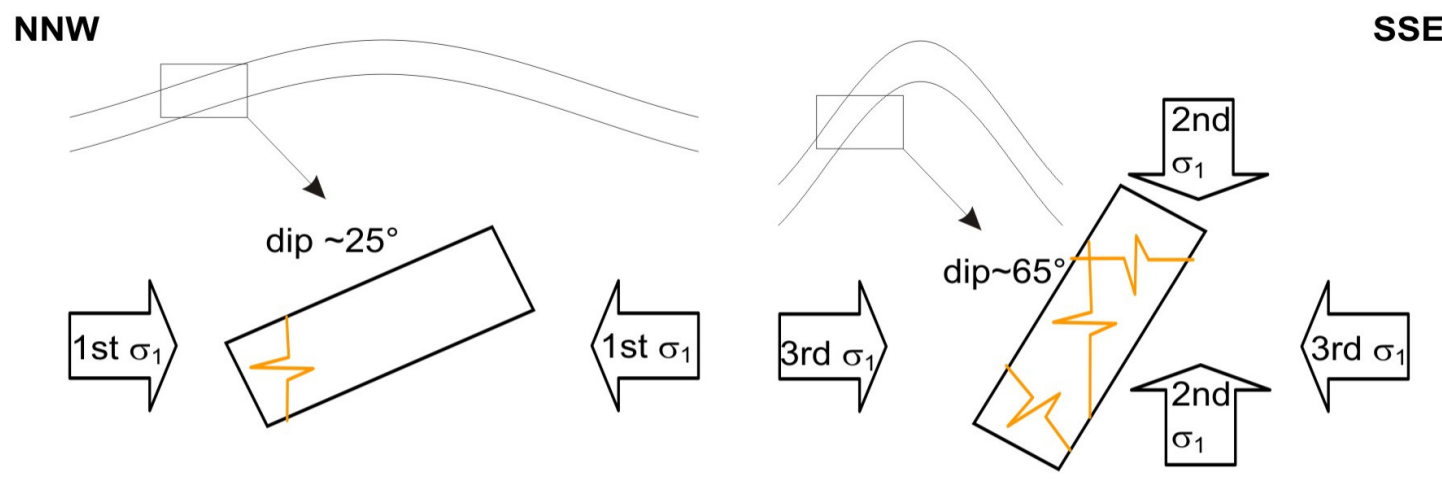

Figure 46: Model of the stylolites formation at outcrop $n^{e r} 46$. The first order stylolites were formed during the inintial stages with bedding diping $25^{\circ}$ and NNW-oriented $\sigma_{1}$. Second order stylolites were formed later when the flank of the anticline was steeper, and vertical $\sigma_{1}$, probably due to overburden stress and/or orogenic collapse. The third stylolite set is the youngest, with horizontal $\sigma_{1}$

The three stylolite sets in Figure 46 can be interpreted as a reflection of three different stress fields. The first order stylolites were formed during the inintial stages of the anticline growth, the bedding dips approximately $25^{\circ}$, with a NNW oriented $\sigma_{1}$. The second order stylolites were formed at a later stage, when the flank of the anticline was much steeper. Here, $\sigma_{1}$ is vertical, most probably due to overburden stress and/or orogenic collapse. $\sigma_{1}$ is horizontal for the third stylolite set, being the youngest; it indicates a compressive tectonic phase.

Although this theory is consistent with other field data, it is still very weak as the dataset is very small and insufficient for a good stress reconstruction. 


\subsubsection{En echelon veins}

In outcrop $n^{e r} 156$ there are vertical en echelon veins with N046E orientation after the bedding is rotated back to horizontal. According to the literature en echelon veins are formed parallel to the $\sigma_{1}$ direction (Pluijm and Marshak, 1997). So for this case it would mean that $\sigma_{1}$ is northeast to southwest. These features, or lens shaped rock fractures, are also known as tension gashes which forms and propagate perpendicular to the maximum direction of extension (Dictionary of Earth Sciences, Oxford).

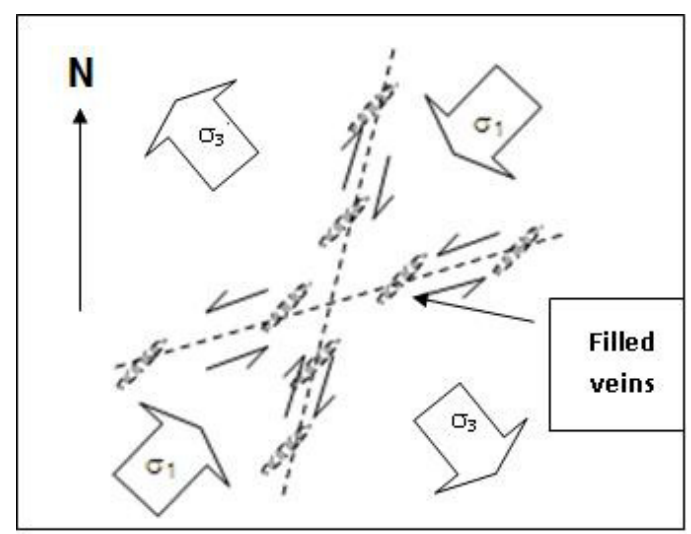

Figure 47: Model of en echelon veins formation.

\subsubsection{Neptunian dykes}

Neptunian dykes are discordant planar sheet-like bodies filled with fine sand and clay and mostly without any structure. They are often associated with soft sediment deformation. A crack is formed perpendicular to the lowest compressional stress, $\sigma_{3}$, and is injected with liquidized unconsolidated sediments (free from Encyclopedia of Sediments and Sedimentary Rocks, Middleton, G.V. and others, 2007). Because it is a soft sediment process we can assume that they are formed not much later than the age of the sediment it crosscuts. See for the $\sigma_{3}$ of the specific outcrops Table 10 .

Table 10: Orientation of the neptunian dykes when bedding is rotated to horizontal per outcrop and formation, and their $\sigma_{3}$.

\begin{tabular}{lrrr} 
& Formation $(M a)$ & Orientation when formed & $\sigma_{3}$ \\
\hline Outcrop $n^{e r} \mathbf{7 5}$ & $\mathrm{J} 5 \mathrm{~b}(\sim 154)$ & $127 / 90$ & $N 127 E$ \\
Outcrop $n^{e r} \mathbf{8 5}$ & $\mathrm{J} 7 \mathrm{~b}-\mathrm{n} 1(\sim 137)$ & $276 / 86$ & $N 096$ \\
Outcrop $n^{e r} \mathbf{1 2 1}$ & $\mathrm{J} 3(\sim 164)$ & $063 / 82$ & $N 063 E$
\end{tabular}




\subsection{Tectonic phases on the Jbel Amsittene}

Table 11 is a summary of all the tectonic features described above with the directions of their main principle stresses or their extension and contraction orientations. According to the formations in which these structures and wedges occur, see Chapter 4, a time label can be attached. The positions of all the outcrops with their structural feature are found on the structural map in the Appendix.

\begin{tabular}{|c|c|c|c|}
\hline Structure & Time $(M a)$ & $\begin{array}{l}\text { Main strain directions } \\
\text { Extension }- \text { Contraction }\end{array}$ & $\begin{array}{r}\sigma_{1} \begin{array}{r}\text { Stress indicators } \\
-\end{array} \sigma_{2}-\sigma_{3} \\
\end{array}$ \\
\hline Folds - Minor phase & $>127$ & $-\sim \sim W-E ?$ & 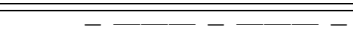 \\
\hline Conjugate sets — Normal fault system & $>127$ & $N N E-S S E-W S W-E N E$ & $231 / 82-077 / 04-346 / 03$ \\
\hline Conjugate sets — Strike-slip system & $<137$ & $N W N-E S E-N N E-S S W$ & $017 / 05-186 / 82-282 / 01$ \\
\hline Neptunian dyke - Outcrop $n^{e r} 85$ & $\sim 137$ & $W-E \longrightarrow-$ & $----N 097 E$ \\
\hline Faults — Syn-sedimentary & $146-137$ & $-(-N N W-S S E$ & $-\longrightarrow---$ \\
\hline Folds — Dominant phase & $<146(-127 ?)$ & $-(-N N W-S S E$ & $-\square---$ \\
\hline Neptunian dyke - Outcrop $n^{e r} 75$ & $\sim 154$ & $W-E--$ & $----N 085 E$ \\
\hline Faults — Post-sedimentary & $<164$ & $-\longrightarrow N N W-S S E$ & $\begin{array}{c}-\square--\square \\
150 / 26--\square-\end{array}$ \\
\hline Stylolites & $<164$ & $-— \sim N N W-S S E$ (Subvertical) & $\begin{array}{l}324 / 23--\square- \\
355 / 64--\square-\end{array}$ \\
\hline En echelon & $<164$ & $N W-S E-S W-N E$ & $N 085 E--\square--$ \\
\hline Neptunian dyke - Outcrop $n^{e r} 121$ & $\sim 164$ & $S W-N E \longrightarrow-$ & $----N 053 E$ \\
\hline
\end{tabular}

Table 11: Resume tectonic features with their assumable age.

Figure 48 is a combination of the subsidence curve from Figure 8 and Table 11.

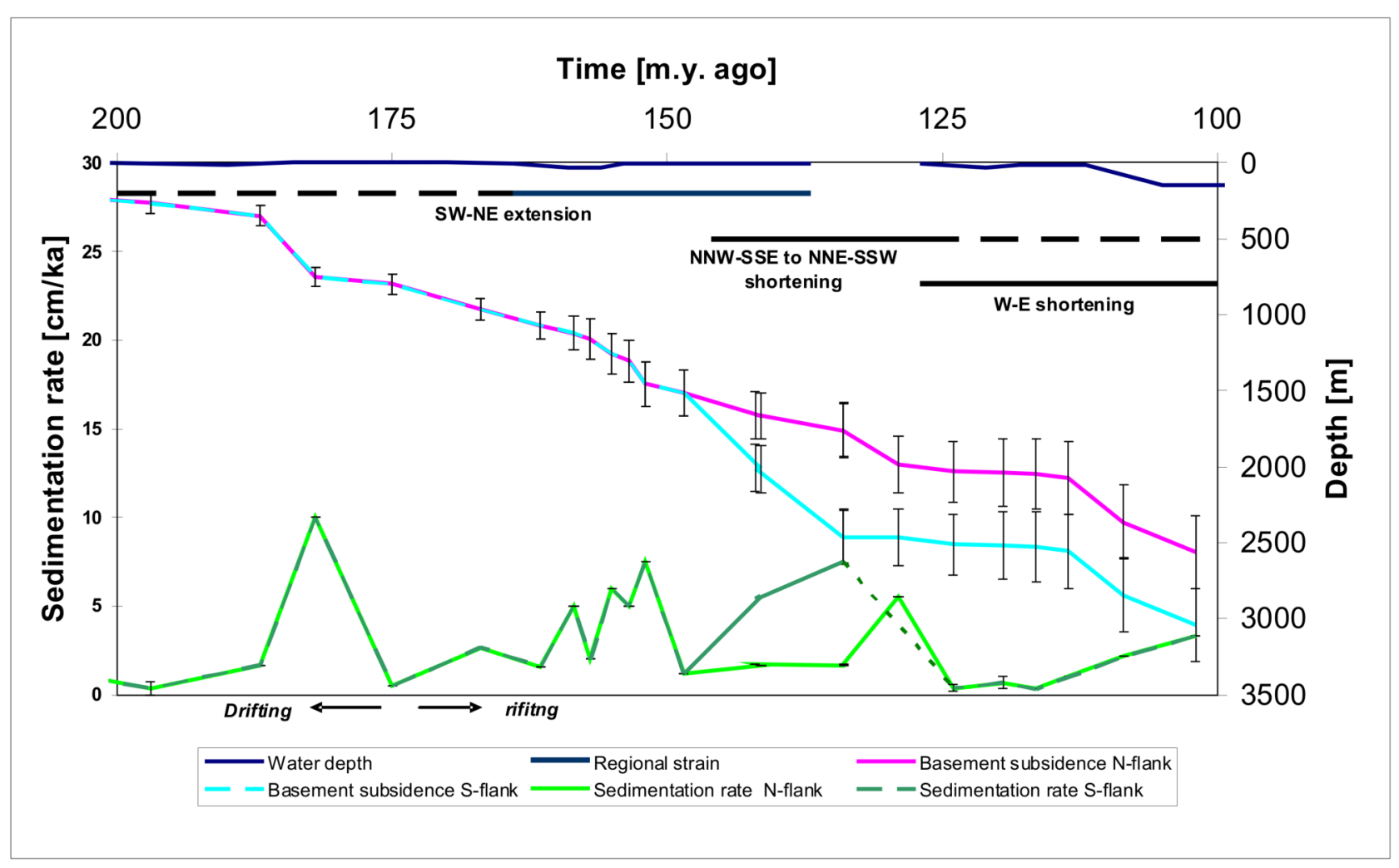

Figure 48: Structural evolution of the Jbel Amsittene. The solid black lines represent phases of regional deformation. The dashed lines are periods in which it is uncertain whether deformation is active. At $146 \mathrm{Ma}$ the basement subsidence is different for north and south flank of the Jbel Amsittene 


\subsubsection{Discussion structural evolution}

The dominant shortening direction, obtained from folds and faults is NNW-SSE. This shortening, during 146 to $127 \mathrm{Ma}$ (Beriasian-Barremian) was resulted in more basement subsidence and higher sediment rate south of the nowadays Jbel Amsittene than north of the Jbel Amsittene (Figure 48). Locally, in the eastern part of the Jbel Amsittene, there is a less dominant and different shortening direction of NNE-SSW (Figure 49). The strain field might change laterally, and not necessarily time-progressively, because of changes in the amount of shortening along the strike of the anticline and/or changes in accommodation space.

Several folds in the J7b-n1 formation (Upper Jurassic), mainly in the eastern part of the field-area, show $\mathrm{E}-\mathrm{W}$ shortening directions. These folds have gentle character, which can make the delimitation of shortening directions more inconclusive. Furthermore, it is unsure whether these shortening directions are local and the folds have been formed during the same time as the NNE-SSW oriented structures, or that they record a secondary deformation phase. If they indeed record a secondary deformation phase, this phase cannot be older than $127 \mathrm{Ma}$, as the folded rocks are of that age.

Several conjugate faults and neptunian dykes have recorded a phase of extension in the Jbel Amsittene area. The direction of extension is roughly SW-NE to W-E. The timing of deformation can be obtained from the neptunian dykes and is 137 to $164 \mathrm{Ma}$; before and partly during the NNW-SSE shortening of the area.

There is very limited information on the stress fields during these periods of deformation. The orientation of maximum stress varies from NNW-SSE to NNE-SSW. This is similar to the variation in shortening direction. 


\section{Discusion}

The formation of the Amsittene anticline started during the Late Jurassic, $146 \mathrm{Ma}$. The shortening direction varied from NNW-SSE to NNE-SSW (Figure 49). In the western part of the field area, the shortening direction was mainly NNW-SSE. Towards the east this changes and becomes NNE-SSW. Also the amount of shortening changes towards the east; maximum shortening of $2 \mathrm{Km}$ near profile $E-E^{\prime}$ and $A-A^{\prime}$, to almost none in the easternmost part of the area, see Figure

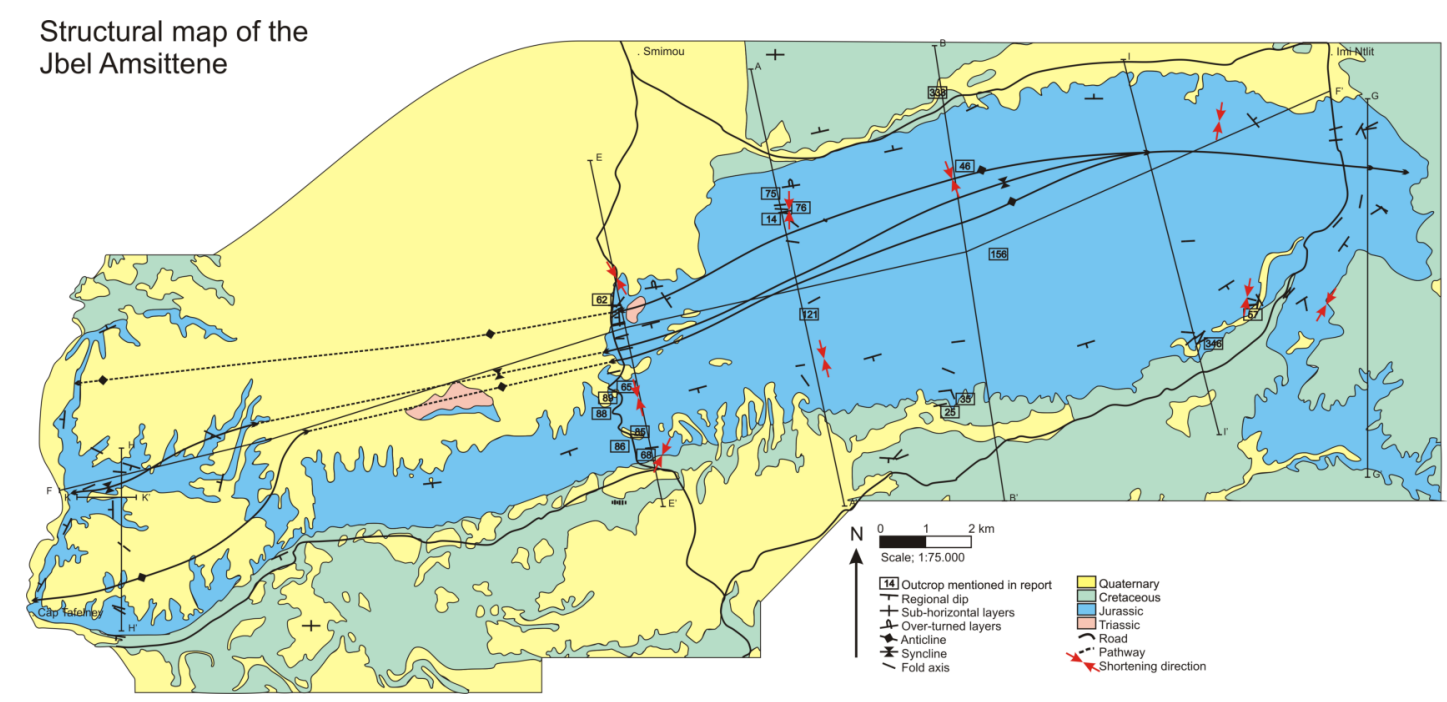

Figure 49: Structural map with the shortening directions.

The geometry of the Amsittene anticline changes laterally. Towards the east it opens and ends, which is in agreement with the decrease in the amount of shortening in this direction. Towards the west it forms two north vergent anticlines. This might be a result of an increased amount of shortening. The mechanism that controls the splitting is unclear: the fold propagation fault might split in two faults. In the westernmost area, along the coast, the anticline is box-model shaped. A fore- and backthrust might be more logical here. Because the area in between the coast and the profile $E-E^{\prime}$ (Appendix 11.2) is mostly covered with marine terraces we do not know how the geometry of the Amsittene anticline changes from two north vergent anticlines to a box-model anticline.

After de opening of the Atlantic Ocean, post-rift subsidence dominated in the Jbel amsittene area until the Late Jurassic. During the Beriasian Hauterivian and possibly Barremian (approx. $120 \mathrm{Ma}$ ) NNW-SSE to NNE-SSW shortening leads to uplift of the bulge and subsidence of the flanks of the Amsittene anticline. The Atlasic deformation phase probably reactivated the anticline.

In the field area, deformation caused by salt diapirism is only local. However, salt probably played a significant role during periods of shortening. The salt acted like a detachment layer between the Palaeozoic basement and the Triassic to Cretaceous rocks. Shortening during the Late Jurassic - Early Cretaceous was probably accommodated by a fault propagation fold that rooted in the salt. The fault plane must dip towards the south, as the Amsittene anticline is north vergent. The strike of the Amsittene anticline corresponds to the strike of the Atlantic rifting transfer (see Chapter 2). The Amsittene anticline might have formed parallel to a transfer fault. Transfer faults form basement steps along which salt easily accumulates. When stress is applied these places are probably first to break. 


\section{Conclusion}

Intensive fieldwork study of the Jbel Amsittene anticline resulted in a dataset that clearly shows:

1. The anticline did not result from salt movement, but from compressional tectonics, as observed by the absence of halokinesis extensional features and the regional orientation of the layers, except in the saltsurrounding areas, where salt diapirism led to local deformation.

2. The anticline formed during the Late Jurassic and Early Cretaceous when NNW-SSE to NNE-SSW shortening led to folding of the area. Shortening initiated in the Beriasian, starting in the west part of the nowadays anticline. Deformation continued and spread over the whole Jbel Amsittene area until the Barremian creating large syn-tectonic wedges in both Late Jurassic, and Early Cretaceous sediments. Disagreeing with Hafid (2006), who stated that during the Tertiary overall NNW to SSE-oriented compression caused the inversion of NE and NNE-striking structures and/or the formation of EW striking salt anticlines and reverse faults, the Jbel Amsittene anticline was mostly formed during the Late Jurassic - Early Cretaceous and experienced relative minor reactivation during the Tertiary Atlasic deformation phase.

3. The shortening varied in the study area. In the west, near profile $E-E^{\prime}$, shortening was the highest and oriented NNW-SSE. Towards the east the shortening decreased and its direction changes towards direction NNE-SSW.

4. The strike of the Amsittene anticline corresponds to the strike of the Atlantic rifting transfer faults, see Figure 40. The Amsittene anticline might have formed in strata that are deposited on top of an old transfer fault, which may have weakened the crust above. The salt in between the basement and the basin fill above acts as a detachment layer.

5. In the middle part of the anticline it is asymmetrical, with a steep, locally overturned, northern limb, suggesting that is a fault propagation fold, with top to the north. This is in agreement with what is observed in the studied seismic line and in contrast with Bouatmani et. al (2003), in which the Amsittene anticline is interpreted to be a fault-bend-fold with top to the south. Near the edges of the area the anticline is more symmetrical.

6. Towards the west, the axial plane of the Jbel Amsittene splits in two, generating two anticlines in this area, making the deformed area broader. Near the coast the anticline forms a box fold. In the eastern part of the study area the continuation of the Jbel Amsittene anticline stops. Profile $G-G$ ' shows an anticline with a small amount of shortening and also the seismic profile 2 of Hafid (2006), some $10 \mathrm{~km}$ to the east, does not reveal any anticline. According to the same interpretation, the anticline prolongs at least $10 \mathrm{~km}$ further into the Atlantic ocean. This is also in line with our Profile $H-H^{\prime}$ and Profile $K-K^{\prime}$. Hafid (2006) also indicates a second anticline further into the Atlantic in a Jurassic to Cretaceous basin. Thus the Jbel Amsittene anticline continues for at least $10 \mathrm{~km}$ into the Atlantic ocean and in the east it ends; it is at least, $40 \mathrm{~km}$ wide.

7. Stresses seem to have been roughly parallel to shortening; NNW-SSE. There is a small dataset that also shows NE-SW maximum stress. Further research is necessary to find out if this signal is true or not and whether it is an expression of a regional stress field, see Chapter 6.

Further detailed and regional structural geologic research is necessary to gain more insights in the Late Jurassic - Early Cretaceous exhumation of the Jbel Amsttene and adjacent areas. There is still little information on the shortening during this period and how it may have affected the Moroccan margin. In the Jbel Amsittene area it would be recommendable to study the en enchelon faults, located on the eastern topographic high of the Jbel Amsittene, and to gain more insights in the geometry of the Amsittene anticline in the western part of the area, near the coast. 


\section{Acknowledgements}

We firstly would like to thank Dr. Giovanni Bertotti of the Vrije Universiteit Amsterdam for his wisdom, support and encouragement during the entire study, and for his helpful reviews. We also acknowledge Drs. Mohammed Gouiza for his contribution and help, especially during the fieldwork. We thank the Vrije Universiteit Amsterdam and the Netherlands Research Centre for Integrated Solid Earth Science for their financial support. 


\section{References}

1. Ait Brahim, L., Chotin, P., Hinaj, S., Abdelouafi, A., El Adraoui, A., Nakcha, C., Dhont, D., Charroud, M., Sossey Alaoui, F., Amrhar, M., Bouaza, A., Tabyaoui, H., Chaouni, A., (2002). Paleostress evolution in the Moroccan African margin from Triassic to Present, Tectonophysics 357, pp. 187-205.

2. Ambroggi, R. (1963). Étude géologique du versant méridional du Haut Atlas occidental et de la Plaine du Souss. Notes et Mém. Serv. Gol. 157, pp. 5-321.

3. Brede, R., Hauptmann, M. \& Herbig, H-G (1992) Plate tectonic and intracratonic mountain ranges in Morocco-The Mesozoic-Cenozoic development of the Central High Atlas and the Middle Atlas. Geologische Rundschau, 81, 127-141.

4. Bouatmani et al., (2003). Bouatmani, R., Medina, F., Ait Salem, A., Hoepffner, C. Thin-skin tectonics in the Essaouira basin (western High Atlas, Morocco): evidence from seismic interpretation and modelling, Journal of African Earth Sciences 37, pp. 25-34.

5. Broughton, P., \& Trepanier (1993). Hydrocarbon generation in the Essaouira basin of western Morocco. Am. Ass. Petr. Geol. Bull., 77, 999-1015.

6. Duffaud et al., (1966). Duffaud, F.C., Brun, L., Plauchut, B. Contribution l'étude stratigraphique du bassin secondaire du Haut-Atlas Occidental (sud-ouest du Maroc). Bulletin Société Géologique France 2, pp. $728-734$.

7. Frizon de Lamotte, D., Saint Bezar, B., Bracne, R., Mercier, E., (2000). The two main steps of the Atlas building and geodynamics of the western Mediterranean, Tectonics 19 (4), pp. 740-761.

8. Gabor C. Tar and Mahmoud Zizi. Expression of the Atlas Inversion Tectonics in Deepwater Offshore Morocco: Influence of Syn-Rift Structures on Post-Rift Deformation.

9. Ghorbal, B., Bertotti, G., Foeken, J., Andriessen, P., (2008). Unexpected Jurassic to Neogene vertical movements in "stable" parts of NW Africa revealed by low temperature geochronology. In preparation.

10. Giese, P. \& Jacobshagen, V. (1992) Inversion tectonics of intra-continental Ranges: High and Middle Atlas, Morocco. Geologische Rundschau, 81 (1), 249-259.

11. Hafid, M., (2000). Triassic-early Liassic extensional systems and their Tertiary inversion, Essaouira Basin (Morocco). Marine and Petroleum Geology 17, pp. 409-429.

12. Hafid, M., Ait Salem A, Bally, A.W., (2000). The western termination of the Jbilet-High Atlas system (Offshores Essaouira basin-Morocco). Marine and Petroleum Geology 17, pp 431-443.

13. Hafid, M., (2006). Styles structuraux du Haut Atlas de Cap Tafelney et de la partie septentrionale du Haut Atlas occidental: tectonique salifre et relation entre l'Atlas et l'Atlantique. Éditions du service géologique du Maroc, Rabat. 
14. Hudec, M.R., Jackson M.P.A., (2007). Terra infirma: Understanding salt tectonics. Earth-Science Reviews, v. 82, pp 124 .

15. Jacobshagen, V., Gorler, K. \& Giese, P. (1988) Geodynamic evolution of the Atlas System (Morocco) in post-Paleozoic times. In V.H. Jacobshagen, The Atlas System of Morocco (pp. 448-499), Lect. Notes Earth Sci., Vol. 15. Berlin, Heidelberg: Springer.

16. Klingelhoefer, F., Labails, C., Cosquer, E., Rouzo, S., Géli, L., Aslanian, D., L. Olivet, J., Sahabi, M., Nouzé, H., and Unternehr, P. (2008). Crustal structure of the SW-Moroccan margin from wide-angle and reflection seismic data (the DAKHLA experiment) Part A: Wide-angle seismic models. Tectonophysics, Article in Press.

17. Laville, E. (1987) A multiple releasing and restraining stepover model for the Jurassic strike-slip basin of the Central High Atlas(Morocco) In W. Manpeozer, Triassic-Jurassic rifting and the opening of the Atlantic Ocean (pp. 499-523) Amsterdam. Elsevier.

18. Laville, E. \& Petit, J. P. (1984) Role of synsedimentary strike-slip faults in the formation of Moroccan Triassic Basins. Geology, 12, 424-427.

19. Le Roy, P., Guillocheau, F., Piqué, A., Morabet, A.M., (1998). Subsidence of the Atlantic Moroccan margin during the Mesozoic, Can. J. Earth Sci. 35, pp. 476-493.

20. Le Roy, P., Piqué, A., (2001). Triassic-Liassic Western Moroccan synrift basins in relation to the Central Atlantic. Opening. Mar. Geol. 172, pp. 359-381.

21. Lister, G.S., Etheridge, M.A., Symonds, P.A., (1991). Detachment models for the formation of passive continental margins. Tectonics 10, pp. 1038-1064.

22. Medina, F., (1995). Syn- and postrift evolution of the El Jadida-Agadir Basin (Morocco). Can. J. Sci. 32 , pp. $1273-1291$.

23. Medina, F., (1994). Evolution structurale du Haut Atlas occidental et des régions voisines du Trias l'Actuel, dans le cadre de l'ouverture de l'Atlantique central et de la collision Afrique-Europe. State Thesis, University Mohammed V, Faculty of Sciences, Rabat, Morocco. n1155, 270 p.

24. Middleton, G.V., Church, M.A., Coniglio, M., Hardie, L.A., Longstaffe, F.J., Encyclopedia of Sediments and Sedimentary Rocks. Publiced by Springer, 2003, ISBN 1402008724, p 136.

25. Piqué, A., Le Roy, P., Amrhar, M., (1998). Transtensive synsedimentary tectonics associated with ocean opening: the Essaouira-Agadir segment of the Atlantic margin. Jour. Geol. Soc. London, 155, 913-927.

26. P. Le Roy, F. Guillocheau, A. Piqué, and A.M. Morabet. (1997) Subsidence of the Atlantic Moroccan margin during the Mesozoic.

27. Pluijm, B. A. van der, Marshak, S. (1997), Earth structure: An introduction to structural geology and tectonics, 2e edition; W. W. Norton \& Company; New York, NY, 10110 USA. 
28. Raïs, N., 1992. Caracterisation mineralogique, cristallochimique et isotopique d'un metamorphisme polyphase de faible intensite. Exemple: les grauwackes cambriennes du Maroc occidental. These, Universite de Bretagne Occidentale, Brest, 193 pp.

29. Samir Bouaziz, Eric Barrier, Mohamed Soussi, Mohamed M. Turki and Hédi Zouari (2002) Tectonic evolution of the northern African margin in Tunisia from paleostress data and sedimentary record.

30. Schaltegger, U., Stille, P., Rais, N., Pique, A., Clauer, N., 1994. Nd and Sr isotopic dating of diagenesis and lox-grade metamorphism of argillaceous sediments. Geochim. Cosmochim. Acta 58, 1471-1481.

31. Stets, J., \& Wurster, P. (1982) Atlas and Atlantic structural relation. In U Von Rad, Geology of the Northwest African continental margin. (pp. 69-85). Berlin-Heidelberg: Springer.

32. Stets, J., \& Wurster, P. (1983) Zur Strukturgeschichte des Hohen Atlas in Marokko. Geol. Rundschau., $70,801-841$.

33. Stewart, S.A., (2006). Implications of passive salt diapir kinematics for reservoir segmentation by radial and concentric faults. Marine and petroleum geology 23, pp. 843-853.

34. Tayebi, M., (1989). Le segment hercynien du haut-Atlas occidental dans les Ait Chaib, Maroc. Stratigraphie, tectonique et role de la zone faillee ouest atlasique. These de Doctorat, Universite d'Aix-Marseille III, 243 pp.

35. Zizi, M (1996) Triassic-Jurassic extension and alpine inversion in Northern Morocco. In P.A. Ziegler, F. Horvath. Structure and prospects of the Alpine basins and Forelands, Peri-Tethys Mem. 2. Mem. Mus. Nat. Hist. Nat.170 (pp.78-101).

36. Zizi, M (1996b) Triassic-Jurassic extensional systems and their Neogene reactivation in Northern Morocco (The Rides prerifaines and Guercif Basin) Ph.D. Thesis, Rice University, Houston. (p.229).

37. Zühlke, R., Bouaouda, M.S., Ouajhain, B., Bechstdt, T., Leinfelder, R., (2004). Quantitative Meso/Cenozoic development of the eastern Central Atlantic continental shelf, onshore Agadir Basin, Morocco. Marine and Petroleum Geology, 21, pp. 225-276.

\section{Internet}

38. Plate tectonic maps and Continental drift animations by C. R. Scotese, PALEOMAP Project (www.scotese.com). 


\section{Appendix}

11.1 Appendix I: Geology map.

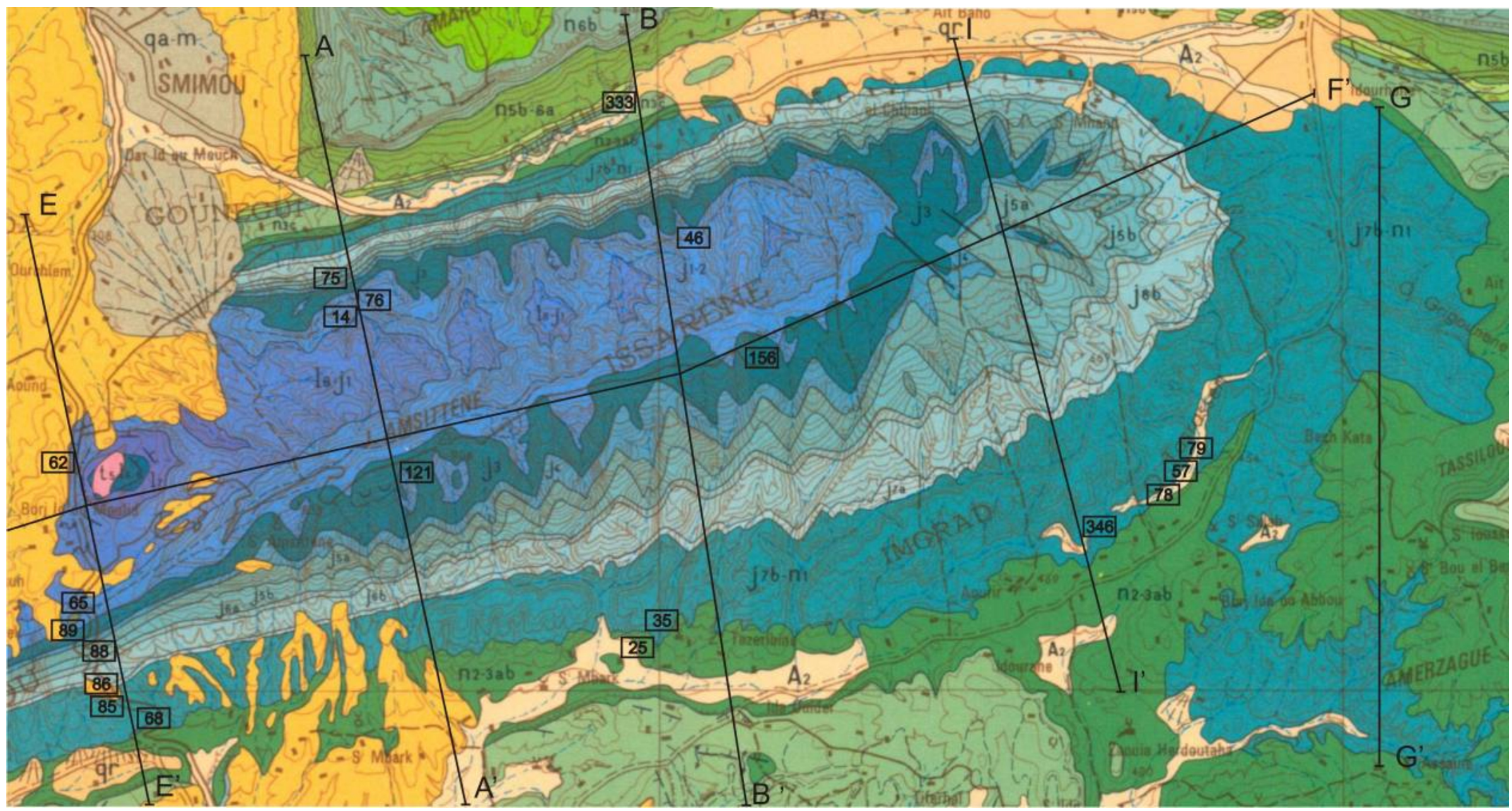


11.2 Appendix II: Structural map.

\section{Structural map of the} Jbel Amsittene

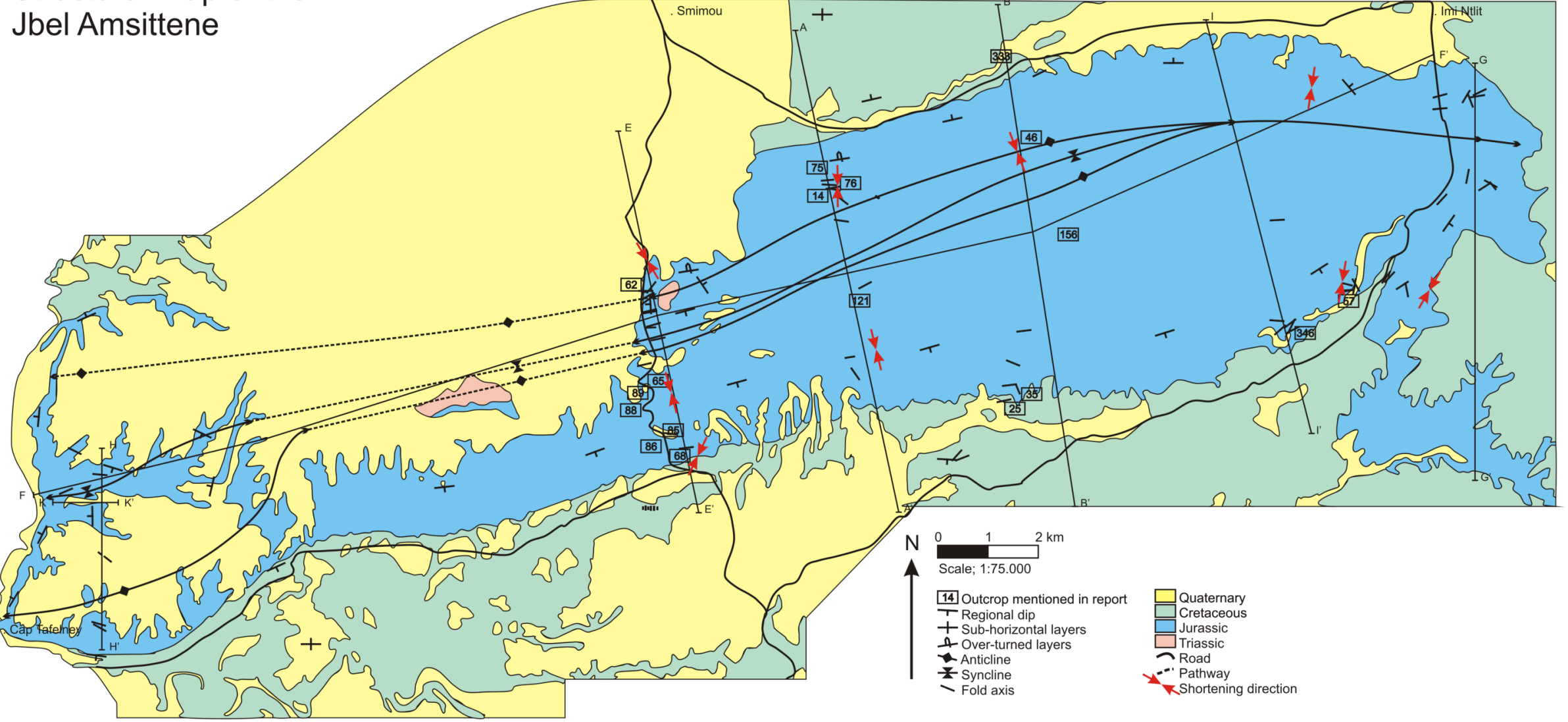


11.3 Appendix III: Profiles $H-H^{\prime}$ and $K-K^{\prime}$.

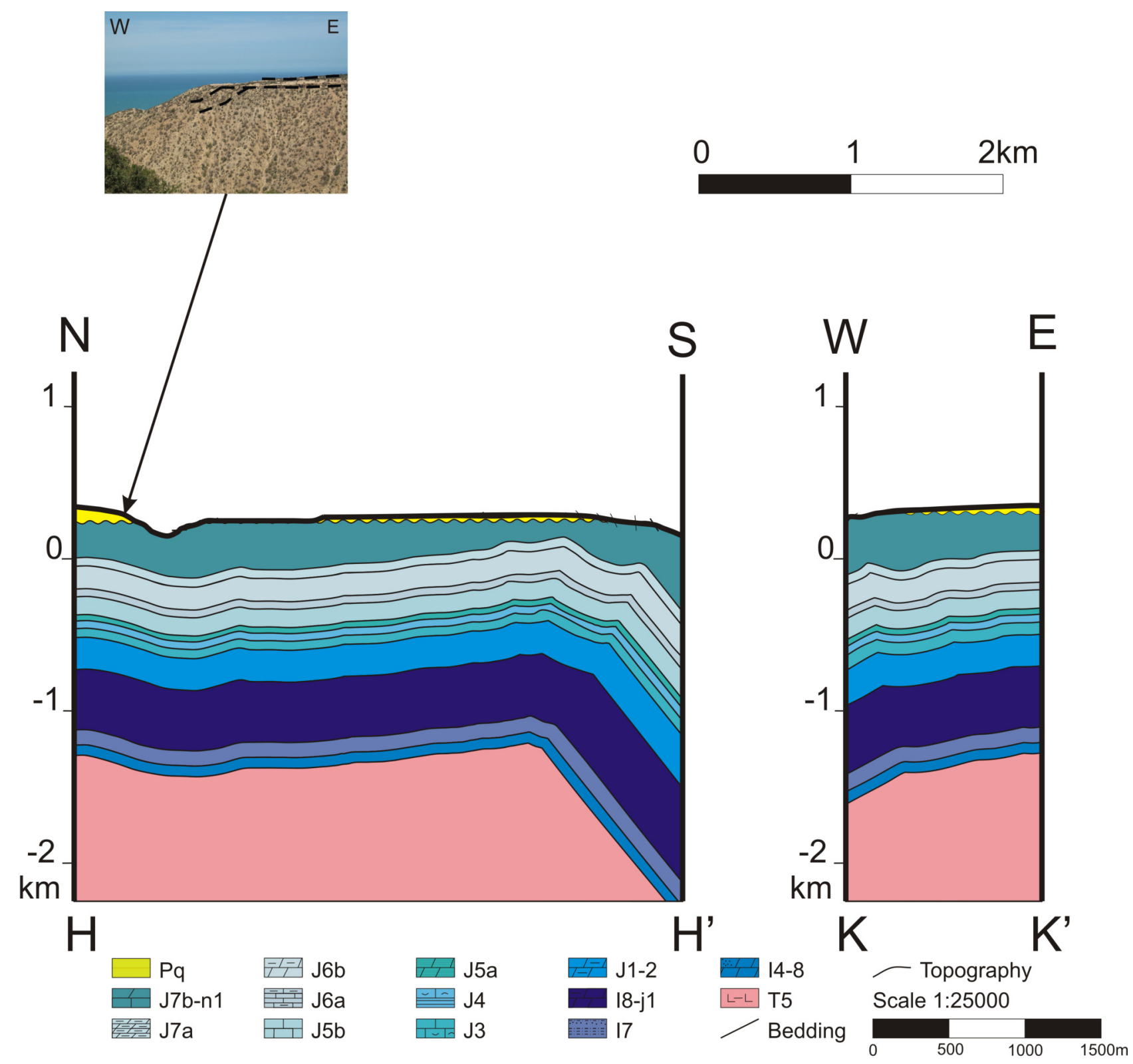


11.4 Appendix IV: Profile $E-E^{\prime}$.

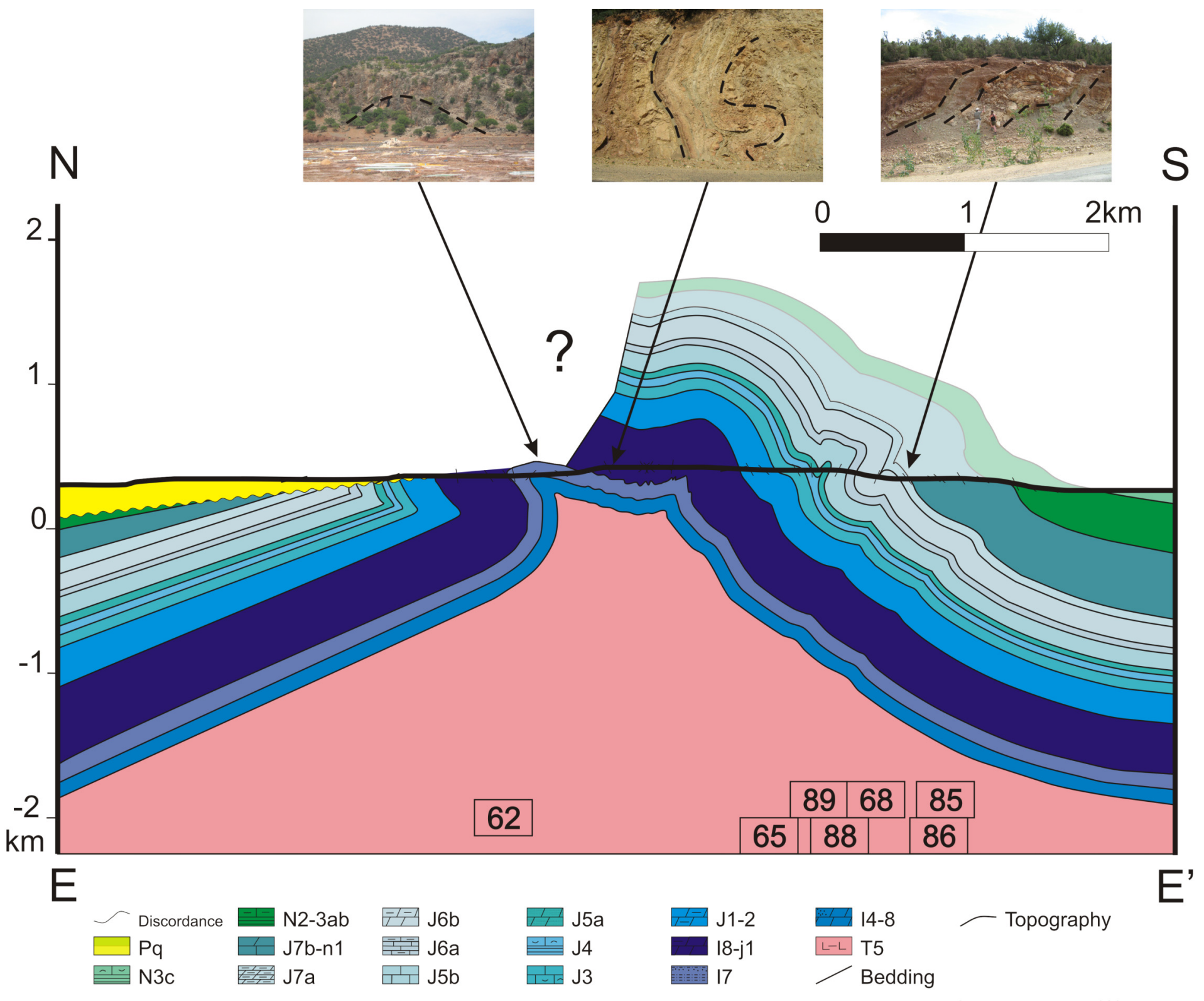




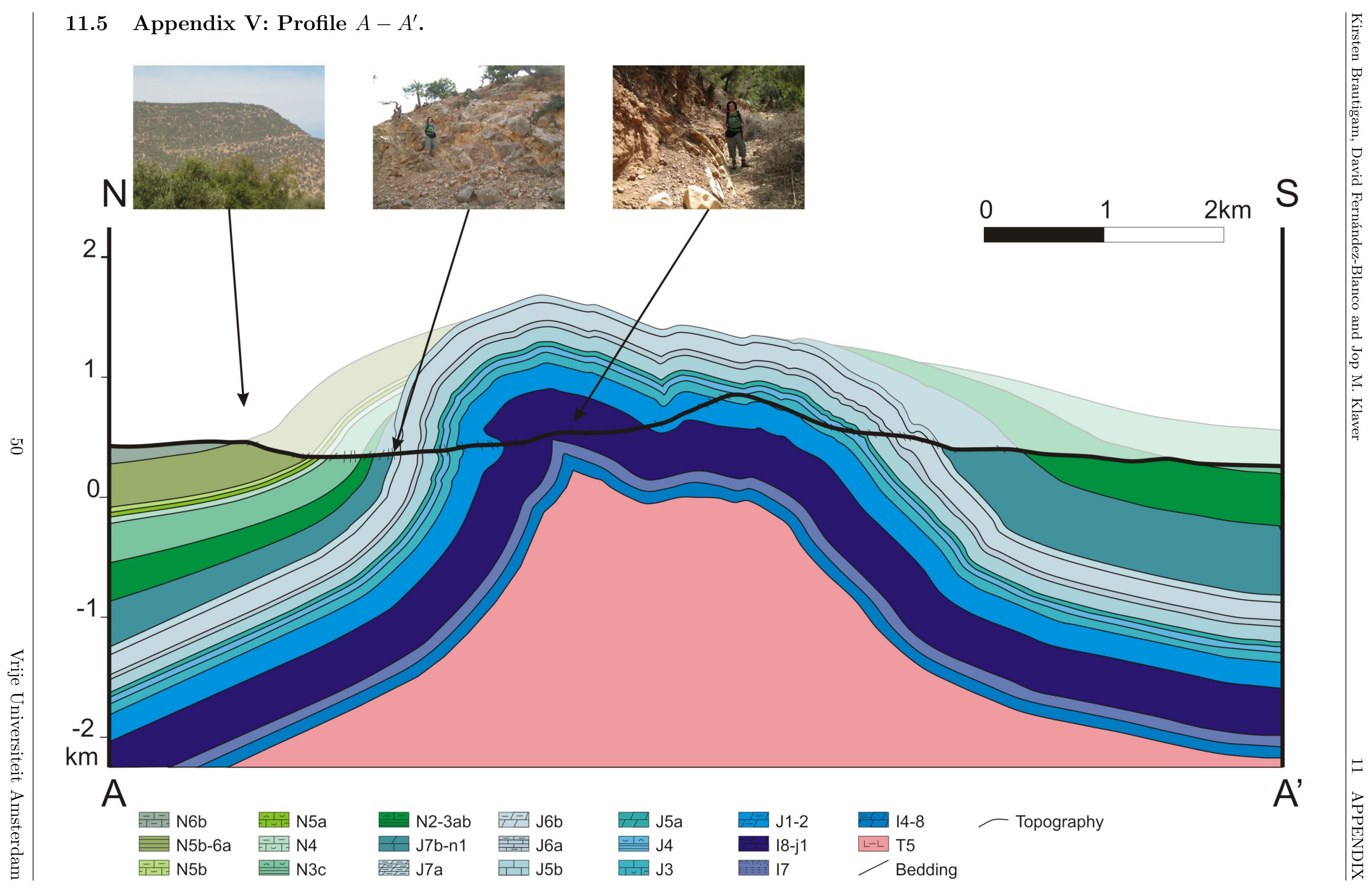


11.6 Appendix VI: Profile $B-B^{\prime}$.

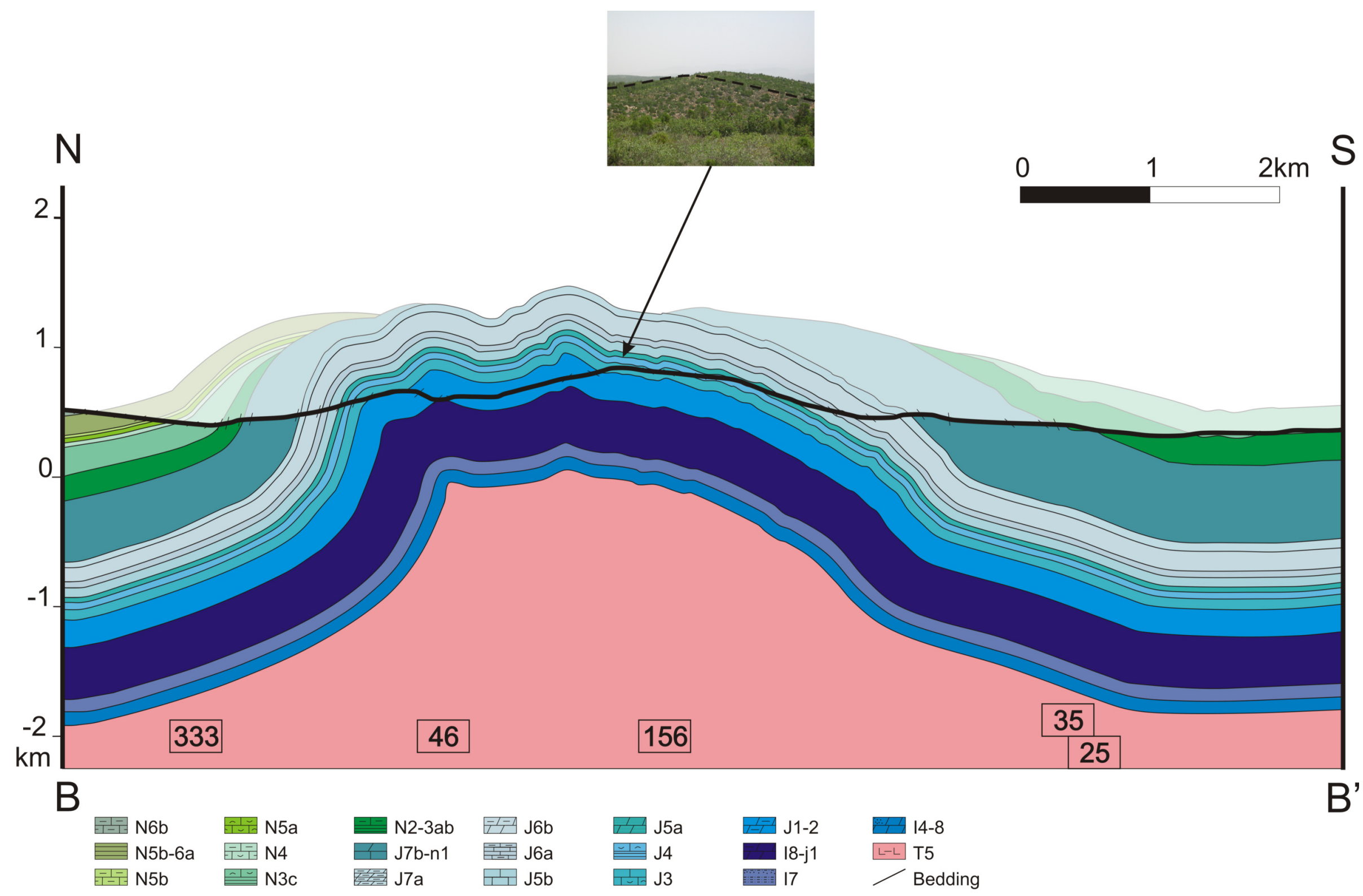




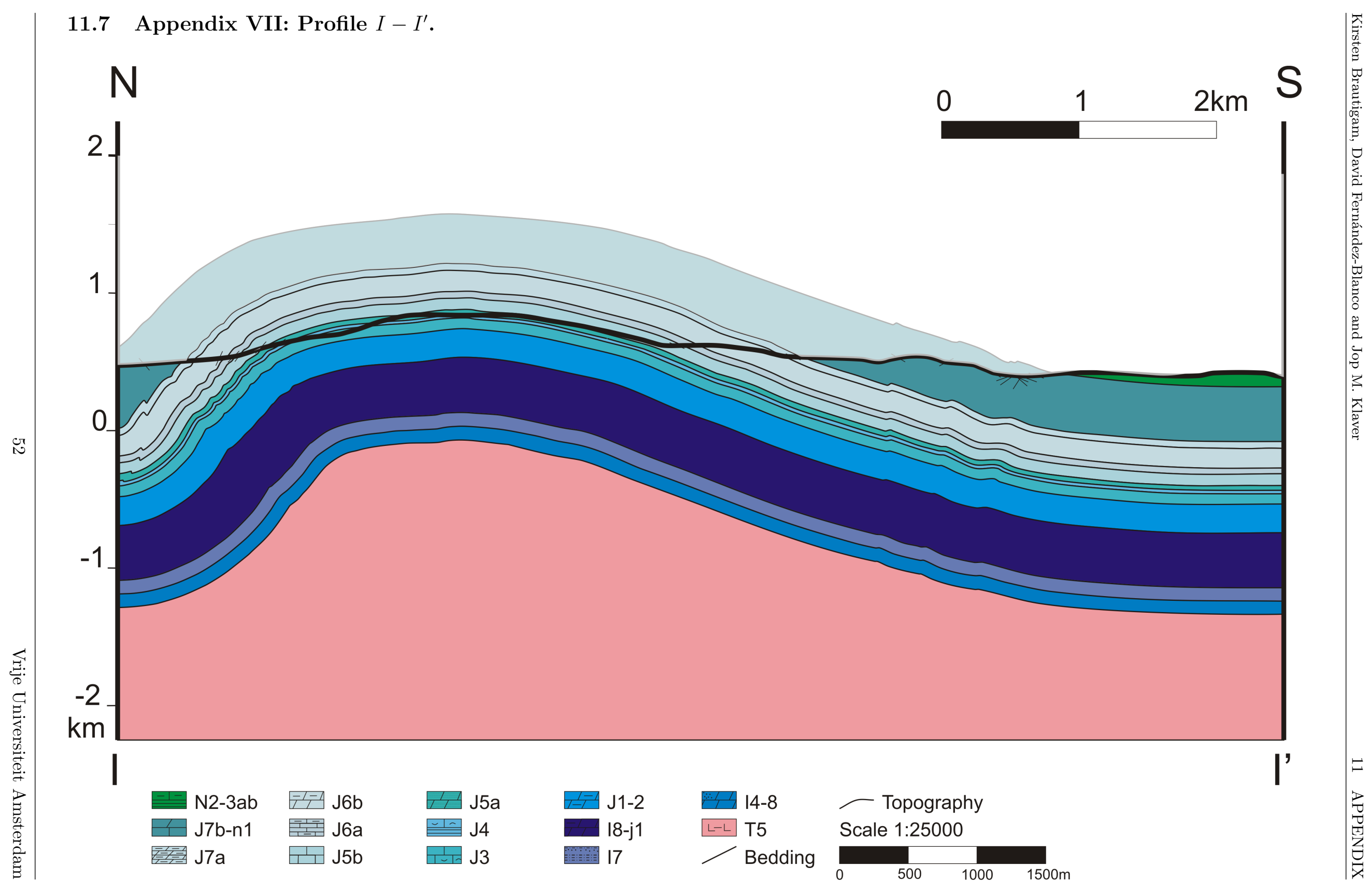




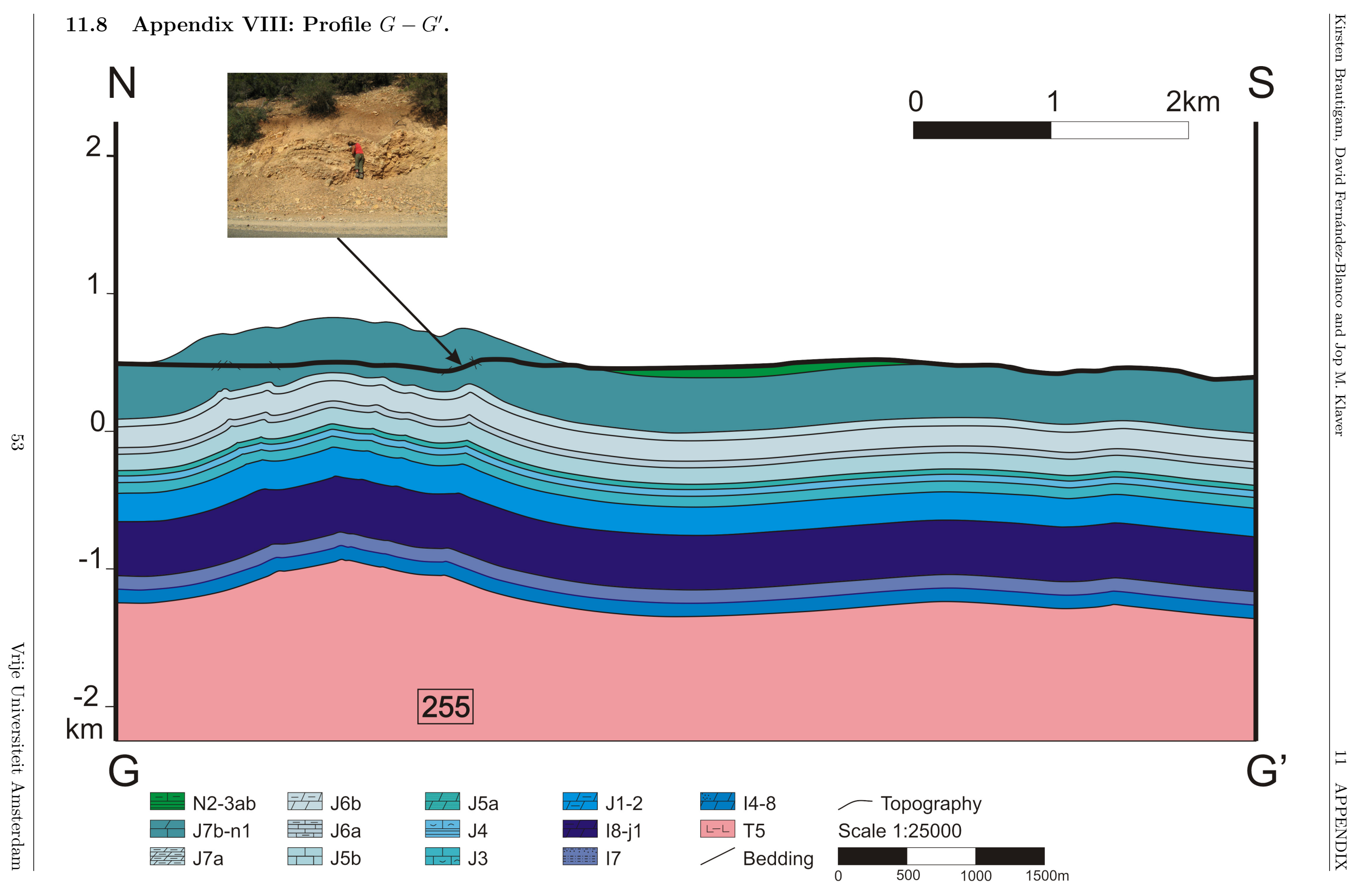


11.9 Appendix IX: Profile $F-F^{\prime}$.

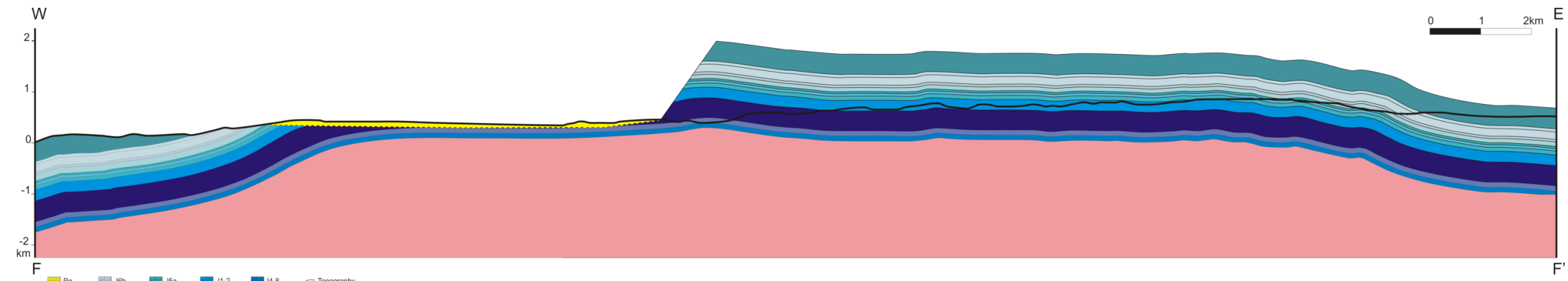

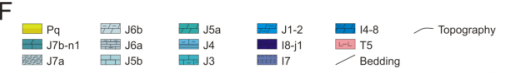

